\title{
PHILOSOPHY OF LANGUAGE AND NEW TRENDS IN TRANSLATION STUDIES AND LINGUISTICS
}

Collective monograph

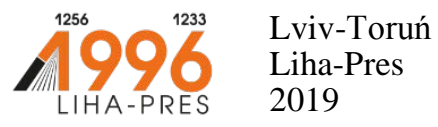




\section{Reviewers:}

Dr Adam Wróbel, School of Polish Language and Culture of Cuiavian University in Wloclawek (Republic of Poland);

Mgr Joanna Skiba, Director of the Center for Foreign Languages, Cuiavian University in Włoctawek (Republic of Poland).

Philosophy of language and new trends in translation studies and linguistics : collective monograph / N. V. Chendey, A. I. Devitska, M. P. Fabian, S. V. Holyk, etc. - Lviv-Toruń : Liha-Pres, 2019. - 164 s.

ISBN 978-966-397-149-0

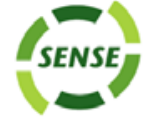

Liha-Pres is an international publishing house which belongs to the category „C” according to the classification of Research School for Socio-Economic and Natural Sciences of the Environment (SENSE) [isn: 3943, 1705, 1704, 1703, 1702, 1701; prefixMetCode: 978966397]. Official website - www.sense.nl. 


\section{CONTENTS}

CONCEPTUAL METAPHORS IN G. BYRON'S POETRY AND ITS UKRAINIAN TRANSLATIONS

Chendey N. V.

ENGLISH AND SLOVAK LANGUAGE SYSTEMS

IN CONTACT: SUPRASEGMENTAL LEVEL

Devitska A. I.

STRUCTURAL APPROACH TO THE STUDY

OF MEANING (ON THE MATERIAL

OF ADJECTIVES IN MODERN UKRAINIAN)

Fabian M. P.

CONCEPT OLD AGE IN ENGLISH:

COGNITIVE-SEMANTIC ANALYSIS

Holyk S. V.

TRANSLATING CULTURALLY

MARKED VOCABULARY

Palchevska O. S.

CONCEPTUAL EQUIVALENCE

AS A CRITERION OF TRANSLATION

QUALITY ASSESSMENT

Popovych N. M.

LEXICAL AND SEMANTIC FEATURES

OF GEOLOGY TERMS IN ENGLISH

Rohach L. V.

TO THE PROBLEM OF ETHNOTHEROTYPES

AND LOCAL NICKNAMES OF THE SLAVS

IN LANGUAGE AND CULTURE

Tyshchenko O. V 


\section{THEOLOGICAL TERMS IN GERMAN:}

GENERAL OVERVIEW

Veresh M. T. 


\section{CONCEPTUAL METAPHORS IN G. BYRON'S POETRY AND ITS UKRAINIAN TRANSLATIONS}

\section{Chendey N. V.}

\section{INTRODUCTION}

This research examines the mechanisms of conceptual metaphors elaboration with special reference to George Gordon Byron's romantic poetry and its Ukrainian translations.

Studies of metaphor have been predominantly dedicated to issues ranging from meaning, structure, components, analogies, typology to the role of metaphors as speech ornaments. These studies, however, neglected the exploration of the continuous connection of metaphors as mental or picturesque representations of the real world and the language used to verbalize these pictures in words ${ }^{1}$.

Despite the majority of literature available on the literary aspects of this linguistic phenomenon, very little research has been done on a cognitive and cultural translation of metaphors. Contemporary studies on metaphor tend to show how metaphors reflect cognitive and cultural human experiences encoded by language as a means of recording human experience and how culture models and constrains this cognition ${ }^{2}$. In particular, this research follows a cognitive approach to poetic metaphors elaboration and translation, especially from and into culturally distinct languages, such as English and Ukrainian.

The most productive within an anthropologic approach to language study proves to be the linguistic and cultural theory of metaphor. Hence, to solve a problem of language and culture interconnection seems to be crucial in recent multiple linguistic works. The study of metaphor has revealed a limited number of possible metaphoric expressions found in a given language. This fact is explained by culturally specified nature of metaphor, advocating an idea that "only images rooted in cultural traditions and native speakers' consciousness can function and develop in language” ${ }^{3}$. Metaphor serves a prism through which human beings view

${ }^{1}$ Lacoff G. The Contemporary Theory of Metaphor / G. Lacoff // Metaphor and Thought / Ed. by Andrew Ortony. 2-nd edition. Cambridge : Cambridge University Press, 1993. P. 202-251.

${ }^{2}$ Katan D. Translating Cultures: An Introduction for Translators, Interpreters and Mediators / D. Katan. Manchester : ST Jerome Publishing, 1999. P. 40.

${ }^{3}$ Quinn N. The cultural basis of metaphor / N. Quinn // Beyond metaphor: the theory of tropes in anthropology. Stanford, 1991. P. 63. 
the world, reflecting specific national vision in an inner language form. V.A. Maslova is a proponent of the theory that studies metaphor as a mode of culture representation. In her opinion, a cultural component of a lexeme presupposes a culturally marked connotation that emerges as a result of interpretation a metaphor's associative basis and its reference to cultural etalons and stereotypes. Undoubtedly, metaphor is anthropologic by its nature and to think metaphorically is an exclusively homo sapiens capacity ${ }^{4}$. Thus, metaphor is an inevitable mental, language and culture element that extends and coins new senses and demonstrates a tight link of individual experience with culture and language community experiences ${ }^{5}$.

Following G. Lakoff and M. Johnson, "a culture may be thought of as providing, among other things, a pool of available metaphors for making sense of reality"; "to live by a metaphor is to have your reality structured by that metaphor and to base your perceptions and actions upon that structuring of reality". ${ }^{6}$ This is related to the fact that people of a given culture use language to reflect their attitudes towards the world in general and the life of the community they live in particular. This in turn gives rise to the reason for the argument in favor of a cognitive approach in translating conceptual metaphors, which takes into account cultural beliefs and values especially between culturally distinct languages, like English and Ukrainian.

It is important to distinguish the way we conceive metaphorically of such things as life and death from the way a particular poet may express such thoughts in language ${ }^{7}$. General conceptual metaphors are not the unique creation of individual poets, but are rather part of the way members of a culture have of conceptualizing their experience. Poets, as members of their cultures, naturally make use of these basic conceptual metaphors to communicate with other members, their audience. However, using the mechanisms of everyday thought, poetic mind extends them, elaborates them and combines them in ways that go beyond the ordinary.

\section{Cognitive equivalence in conceptual metaphors translation}

In cognitive linguistics, metaphor is often given a cognitive function in which human beings draw upon the experience of each other or non-

\footnotetext{
${ }^{4}$ Маслова В. А. Лингвокультурология: учеб. пособие / Валентина Авраамовна Маслова. М. : Академия, 2001. С. 92.

${ }^{5}$ Опарина Е. О. Исследование метафоры в последней трети ХХ века / Е. О. Опарина // Лингвистические обзоры в конце XX века. М. : Институт языкознания РАН, 2000. С. 200.

${ }^{6}$ Lacoff G., Johnson M. Metaphors We Live By / G. Lacoff, M. Johnson. Chicago: The University of Chicago Press, 1980. P. 12.

${ }^{7}$ Lacoff G., Turner M. More than cool reason: a field guide to poetic metaphor / G. Lacoff, M. Turner. Chicago: University of Chicago Press, 1989. P. 16. 
human surroundings or even other concepts or images. G. Lakoff and M. Johnson (1980) define metaphor as a means to understand one domain of experience (the target domain) in terms of another, a familiar one (source domain). This usually takes the form of analogy or comparison between two existent entities or one existent entity and another one assumed to exist. To say that someone is a 'lion', for example, reveals that a link has been established between that individual (tenor) and the 'lion' (vehicle) as a symbol of bravery or strength. Therefore, metaphors are 'conceptual' phenomena in which the source domain is mapped onto the target domain. To put it differently, the structural components of the source conceptual schema are transferred to the target domain ${ }^{8}$.

A distinguishing characteristic of recent multileveled theories of translation equivalence is a focus on semantic components, i.e. pragmatic, semantic and syntactic aspects. Besides, a pragmatic component refers to the sphere of adequacy, while semantic and syntactic ones define translation equivalence ${ }^{9}$.

Conceptual metaphor equivalence in a literary text cannot be included into any known level of the equivalence theory. Though this category proves to be semantic either, it also contains linguistic and psychological components on a pragmatic equivalence level. Basically, the majority of equivalence theories do not put to the fore an imagery language component. Meanwhile a conceptual equivalence specification in a literary text enables to take into account psychological and cognitive language aspects that define not only modes of imagery in a text, but modes of thinking in general. For instance, an association, objectified in conceptual codes, combines single concepts into a conceptual sphere, or equivalence of target language and source language references on the level of senses and perception codes predicts psychological impact on a recipient.

O. A. Yasynetska in her study of metaphor translation as a means of conceptual picture representation points out that most proponents of cognitive theory of metaphor consider entirely its conceptual level in two languages, totally neglecting a language level of metaphor realization in them. However, the reproduction of senses and images, not meanings, proves to be a necessary condition of metaphor translation ${ }^{10}$.

${ }^{8}$ Lacoff G., Johnson M. Metaphors We Live By / G. Lacoff, M. Johnson. Chicago: The University of Chicago Press, 1980. P. 34.

${ }^{9}$ Newmark P. Approaches to Translation / Peter Newmark. Oxford : Pergamon Press, 1981. P. 45 .

10 Ясинецька О.А. Переклад метафори як мовна репрезентація концептуальних картин світу / О.А. Ясинецька // Філологічні трактати. 2010. Т. 2. № 1. Вид-во СумДУ С. 96. 
A culture factor can play a crucial role in the way metaphors of one language are translated into another due to various modes of perception and categorization pertain to different language communities. It is thought that there is no simplistic general rule for the translation of metaphor, but the translatability of any given SL metaphor depends on 1) the particular cultural experiences and semantic associations exploited by it; and 2) the extent to which these can, or cannot, be reproduced non-anomalously into the TL, depending on the degree of overlap in each particular case ${ }^{11}$.

This view of culture suggests that, when translating a text of any other culture, one needs to be aware not only of the patterns of thinking, and acting in one's own culture, but also of the TL's cultural models of reality. E. Nida described the 'best' translation as the one capable of evoking in the TL reader the same response as the SL text does to the SL reader. ${ }^{12}$ Although this seems to be a rather unreachable objective, some of it can be achieved provided that the following two conditions are satisfied. First, the translator must understand the way in which receptive readers perceive the world and structure their experience. Second, s/he must also try their best to find a way to accommodate a text to the experience of the targetlanguage reader, and to the way it is recoded in the TL. An argument in favor of a cognitive approach to the translation of metaphors derives from the notion of 'cognitive equivalence', where metaphors can be translated from one language to another with a minimum degree of loss. ${ }^{13}$ For this reason, metaphors are thought to be looked at as cognitive constructs rather than mere linguistic entities ${ }^{14}$. Hence, it remains essential to regard their semantic associations, typical of a given language. In other words, metaphors represent instances of how people conceptualize their experience and how they record it verbally in their language.

In accordance with a cognitive approach to metaphor translation, a culture component that underlies a conceptual metaphor enables to reveal differences in how various cultures constrain human experience. The hypothesis is built on two scenarios:

1) if a conceptual mapping from one domain onto another is similar in a TL metaphor, then a conceptual shift does not occur;

\footnotetext{
${ }^{11}$ Katan D. Translating Cultures: An Introduction for Translators, Interpreters and Mediators / D. Katan. Manchester : ST Jerome Publishing, 1999. P. 28.

${ }^{12}$ Nida E. Towards a Science of Translation / E. Nida. Leiden: E. J. Brill, 1964. 287 p.

${ }^{13}$ Mandelblit N. The Cognitive View of Metaphor and its Implications for Translation Theory. Translation and Meaning / N. Mandelblit. Maastricht : Universitaire Press, 1995. P. 483495.

${ }^{14}$ Kövecses Z. Metaphor and Emotion: Language, Culture and Body in Human Feeling / Z. Kövecses. Cambridge: Maison des Science de L'Homme and Cambridge University Press, 2000. P. 14.
} 
2) if a conceptual mapping from one domain onto another is different in a TL metaphor, then a conceptual shift occurs.

Doing translation within the earlier mentioned scenarios, it is possible to define commonalities in metaphors functioning in different languages along with a 'degree' of their cultural distance.

P. Newmark suggested his classification of the possible ways of metaphor translation:

1) an image reproduction in a TL (natural to a recipient language);

2) a SL image substitution by a standard TL image (equivalent metaphor substitution);

3) a metaphor rendering by means of simile (when image is preserved, but lower degree of expressiveness is inevitable);

4) a metaphor rendering by means of simile, accompanied by a vast explanation (which assists comprehension, but leads to a loss of expressiveness);

5) a reproduction of metaphoric meaning through a paraphrase (when a metaphor is obscure or excessive in a TL);

6) a metaphor omission in case it is unnecessary;

7) a metaphor reproduction and its meaning specification that intensifies an image ${ }^{15}$.

For the translation of conceptual metaphors V. Nikonova proposed specific linguistic and cognitive mechanisms amid which she singles out extension, restriction, amelioration, degradation, questioning and combination of the content of correlating metaphor concept ${ }^{16}$.

In "Cognitive Translation Hypothesis" N. Mandelblit proposed two schemes of cognitive mapping conditions (i.e. Similar Mapping Condition (SMC) and Different Mapping Condition (DMC)). The author intended to show that "the difference in reaction time is due to a conceptual shift that the translator is required to make between the conceptual mapping systems of the source and target languages. She found out that metaphorical expressions take more time and are more difficult to translate if they exploit a cognitive domain different from that of the target language equivalent expression. According to the hypothesis, the reason for this delay, difficulty and uncertainty in the translation of different domain metaphors is the search for another conceptual mapping (i.e. another cognitive domain). That is to say the fact that metaphors almost always exploit such different cognitive domains implies the search for a cognitive

\footnotetext{
${ }^{15}$ Newmark P. The Translation of Metaphor / P. Newmark // Babel, 1980. P. 93-100.

${ }^{16}$ Ніконова В. Г. Реконструкція концептуальної метафори: ідентифікація концептукореляту (на матеріалі трагедій В. Шекспіра) / В. Г. Ніконова // Нова філологія: зб. наук. праць. Запоріжжя: ЗНУ, 2007. № 31. С. 41-44.
} 
equivalence for SL metaphors in the TL. In other words, the translator is called upon to play the role of a proxy agent doing the act of conceptual mapping on behalf of the TL reader. If they can touch upon a similar TL cognitive domain, then their task will be fulfilled quite successfully and easily. If not, they have to look for the cognitive domain that fits in the TL as the SL one does. The result of the first action is often an equivalent TL metaphor or - under the worst conditions - a TL simile. The result of the second action, however, is open to many possibilities, of which rendering the SL metaphor into a TL one is the least likely. Thus, a metaphor might be rendered into a simile, a paraphrase, a footnote, an explanation or - as a last resort - it can be omitted ${ }^{17}$.

Therefore, the attempts of literal rendering or mere linguistic meaning transference of the metaphoric expressions from one language to another are deemed to result in a noticeably bad product, especially when these expressions draw on culture-specific methods of thinking rather than on shared or universal notions.

Referring to cultural aspects and drawing on the general guidelines of the cognitive framework (i.e. the cognitive equivalent hypothesis) for metaphor translation, we used two sets of original English and translated Ukrainian poetic metaphors. The first set comprises metaphors of similar mapping conditions reflecting shared ideas, but verbalized differently in the TL (expressed by different lexical items). The second set contains metaphors of different mapping conditions, which lack conceptual equivalents in the TL.

\section{Metaphors of similar mapping conditions but verbalized differently in Byron's original poetry and its Ukrainian translations}

This group includes metaphors, verbalizing basic concepts of LIFE, LOVE, TIME and DEATH that are characteristic of any language. They represent common conceptual mechanisms of their creation both in original poetical texts and their Ukrainian translations.

SL “Oh, Snatched Away in Beauty's Bloom” Oh! Snatched away in beauty's bloom, On thee shall press no ponderous tomb; But on thy turf shall roses rear Their leaves, the earliest of the year; And the wild cypress wave in tender gloom.

TL “Зірвали дивний першоцвіт” Зірвали дивний першоцвіт, Затис його могильний лід. Але крізь прах життя зроста - Троянд

\footnotetext{
17 Mandelblit N. The Cognitive View of Metaphor and its Implications for Translation Theory. Translation and Meaning / N. Mandelblit. Maastricht : Universitaire Press, 1995. P. 483-
} 495. 
розкриваються вуста Під сутінь кипарисних вim. (Translation by V. Bohuslavska)

In this poem a predicative metaphorical construction "on thy turf shall roses rear their leaves, the earliest of the year" represents the author's original metaphor LIFE IS A ROSE, created due the cognitive mechanism of restriction of a basic metaphor LIFE IS A PLANT. In the translated text the same metaphor is reconstructed, but in a genitive metaphorical construction: “але крізь прах життя зроста - троянд розкриваються вуста". Rose is a kind of flower that implicitly indicates the concept of life and love in poetry. The metaphorical comparison is based on a fixed association of the content of a source concept with a meaning of life, love and youth. In Byron's poetry ROSE is capable of regenerating: "roses rear their leaves", while in translation ROSE is personified and transferred into “троянд розкриваються вуста". The translator endues the rose with anthropomorphic characteristics, aimed at the explication of its spiritual nature. It must be said that in Ukrainian poetical texts the method of personification of plants is very common due to the metaphoric paradigm “a person - a plant”, taken from the national folklore.

Metaphors conceptualizing LOVE also belong to those of similar mapping conditions in Byron's original poetry and its Ukrainian translations.

SL "To Caroline" Yet still, this fond bosom regrets, while adoring, That love, like the leaf, must fall into the sear, That Age will come on, when Remembrance, deploring, Contemplates the scenes of her youth, with a tear;

TL “Кароліні" Та з ніжності серие порине у жаль, Бо листям любов опадає, У згадиі відлуниться юні межа, Ї̈ у сльозах виглядаю. (Translation by V. Bohuslavska)

Individual author metaphor LOVE IS THE LEAVE is a subsidiary model within a basic conceptual metaphor LOVE IS A PLANT, actualizing the meaning of fugacious happy moments in life. In original the conceptual metaphor is realized in a metaphorical comparative construction: "That love, like the leaf, must fall into the sear", but in translation it is presented in a genitive metaphor: "бо листям любов onadae". In both cases the author's metaphor implies a polysemantic complex indicating not only an emotional meaning of love, but the motif of ageing (summer is the season of blossoming that verbalizes adolescence, while autumn symbolizes an old age). The latter meaning is reconstructed in the following two lines: "That Age will come on, when Remembrance, deploring Contemplates the scenes of her youth, with a 
tear” - “У згадиі відлуниться юні межа, Ї̈ у сльозах виглядаю” that intensify the meaning of time fleeting.

Similar conceptual modeling is observed in TIME metaphorization in English and Ukrainian.

SL "To Time" Time! On whose arbitrary wing The varying hours must flag or fly Whose tardy winter, fleeting spring, But drag or drive us on to die - Hail thou! who on my birth bestowed Those boons to all that know thee known; Yet better I sustain thy load, For now I bear the weight alone.

TL “До Часу” $O$ часе, твій політ незримий 3 собою все несе, мов пил. Летючі весни, гайні зими Женуть усіх нас до могил. Хай приділив талан жорстокий Мені до віку, часе, ти - Та легші ті вериги, доки Мені самому їх нести. (Translation by D. Palamarchyk)

In this poem time is personified being compared to bird's flight that "drags or drives us on to die" "on arbitrary wing”. At this a special emphasis is put not only on time's continuousness, but its varying nature as well: "the varying hours must flag or fly", where the modal verb must expresses the meaning of obligation, intensifying the image of fatality. The feeling of inevitability is created by the attributive metaphorical constructions "tardy winter", that is associated with death, and "fleeting spring", that is associated with youth, and that have been adequately transferred into "летючі весни, гайні зими" in Ukrainian translation. The DEATH IS WINTER metaphor is a natural metaphoric conception of life and death, since spring is the season when new plant and animal life is born, while winter signals the dormancy or hibernation of plants and animals. However, life and death are such all-encompassing matters that there can be no single conceptual metaphor to comprehend them.

TL "When Coldness Wraps This Suffering Clay" Above or Love Hope - Hate - or Fear, It lives all passionless and pure: An age shall fleet like earthly year; Its years as moments shall endure. Away - away without a wing, O're all - through all - its thought shall fly, A nameless and eternal thing, Forgetting what it was to die.

SL “Коли Позаземна Зима” Понад Любов, Надію, Жах Жагою чистою зорить. І плине час, i де межа - Роки для Вічності, як мить. Вперед, вперед - хоча без крил - Крізь простір дух сяга глибин, Він незбагненне підкорив, Дарма, щчо мав померти він.(Translation by V. Bohuslavska)

A TIME IS SOMETHING MOVING metaphor has two versions: in both we are located at the present and are facing towards the future with the past at our back. In the original and translation we understand change of time as change of location: "Away - away - without a wing" “Виеред, вперед - хоча без крил" as resulting from an action by an 
agent. The agent is identical to a bird and time is winged, being personified it can fly.

Our understanding of life and death is very much bound up with our understanding of time. This is because death is inevitable and because the mere passage of time can be seen as bringing about inevitable events. One of major cultural models of life is that each of us is allotted a certain fixed time on earth. According to the conventional metaphor of death as departure, we conceive of death as departure away from here, without possibility of return, on a journey, perhaps in a vehicle ${ }^{18}$. We may take it that Byron uses this metaphor, but filling in the slots, that is elaborating it, in an interesting way.

SL "Sun of the Sleepless" Sun of the sleepless! melancholy star! Whose tears beam glows tremendously far, That show'st the darkness thou canst not dispel, How like art thou to Joy remembered well! So gleams the past, the light of other days, Which shines, but warms not with its powerless rays: A night-beam Sorrow watcheth to behold, Distinct, but distant - clear - but, oh how cold!

TL “Сонце безсонних” Безсонних сонце, зірко жалібна! Твій слізний пломінь криє далина, Безсилий пітьму він перемогти. Як на минуле щуастя схожа ти! Отак нам світить відблиск інших днів, Але не гріє, хоч би як виднів. Так в ніч сумну минувшина зійшла: Хоч видна - та здаля, ясна - та без тепла. (Translation by H. Kochur)

Being away from here is characterized by the specific case of departure. The vehicle is an unusual one - "the moonless air". These ways of making the DEATH IS DEPARTURE metaphor specific add considerable conceptual content to the metaphor of death as departure. Eternal space, after all, in not merely being away from here. It is "rayless and pathless", it is unwanted, it assumes that it is an unusual state when "sun was extinguished" and so on. The moonless air, moreover, is not something that takes us swiftly or securely to a given destination as it is a departure to the unknown. It is something we are not in control of because we are at the whim of the currents, and it leaves us exposed to the elements.

A LIFETIME IS A DAY is a metaphor in which birth is dawn, maturity is noon, old age is twilight, the moment of death is sunset, and the state of death is night. This metaphor implies death's coldness in night's coldness, since death is naturally substituted by night.

LIFE IS A SUN - ЖИТТЯ С СОНЦЕ is implicitly realized both in the original and translation through a combination of associatively linked units

${ }^{18}$ Lacoff G., Turner M. More than cool reason: a field guide to poetic metaphor / G. Lacoff, M. Turner. Chicago : University of Chicago Press, 1989. P. 5. 
that explicitly indicate the Sun's attributes. "Sun of the sleepless!" „Соние безсонних" is a genitive metaphorical construction that contains an extended poetic image of the metaphorical composition, which is realized in the whole text. However, the lexemes, expressing the sun's features, are used in a sharp contrast to all positive meanings via the procedure of questioning of the basic concept. The poet calls the sun a "melancholy star" - “зірка жалібна" which lost its ability to lighten darkness: "Whose tears beam glows tremendously far, That show'st the darkness thou canst not dispel" - "Твій слізний пломінь криє далина, Безсилий пітьму він перемогти". A pessimistic feeling of reality is created by the image of the sun with its powerless rays: "the light of other days, Which shines, but warms not with its powerless rays" - "Отак нам світить відблиск інших днів, Але не гріє, хоч би як виднів". A personified Darkness reins the universe.

\section{Metaphors of different mapping conditions in Byron's original poetry and its Ukrainian translations}

In this section the attempt has been made to establish not only the specificity of metaphors functioning in culturally distinct languages, but to indicate national and cultural components in metaphorical elaborations and extensions. In English and Ukrainian poetic traditions special modes of presenting metaphorical meanings have been formed, which causes semantic and functional divergences in metaphorical conceptualization of some basic universal notions. Despite the similarity of the filters in different languages, i.e. metaphorical analogy that enables metaphorical transformation, their metaphorical presentation does not coincide. As a result associative and image lacunas emerge, which testify to subjective perception and evaluation of the world by different cultural background language communities.

TL "I Saw Thee Weep" I saw thee weep - the big bright tear Came o're that eye of blue; And then methought it did appear A violet dropping dew: I saw thee smile - the sapphire's blaze Besides thee ceased to shine; It could not match the living rays That filled that glance of thine. As clouds from yonder sun receive A deep and mellow dye, Which scarce the shade of coming eve Can banish from the sky,

SL “Я бачу твої сльози” Ти плачеш - адамант сльози Затьмарюе блакить, Краплина росна від грози $B$ барвінку мерехтить. Всміхнешся - спалахом сапрір Сяйне з тремтливих вій. Зустрівши твій промінний зір, Тлумить небо свій. Сховає соние вовна хмар В пухнастій глибині - Чи допоможе хто тягар Підважити мені? (Translation by V. Bohuslavska) 
Metaphorical extension results in the reconstruction of a composition TEAR - DEW - GEM indicating the evaluative component in the emotional poetic image. Thus, the image of sapphire in the original, and added by the translator an image of a diamond in Ukrainian, considerably extends the poetic expression of emotional feeling: "I saw thee smile the sapphire's blaze Besides thee ceased to shine" - "Всміхнешся спалахом сапрір Сяйне з тремтливих вій". Besides, the meaning of first love is implicitly indicated by "a violet" in the English text, which has been correspondingly substituted in the translation by "барвінок" in the line with the national folklore: "A violet dropping dew" - "В барвінку мерехтить".

The metaphorical transformation within a paradigm "an atmospheric phenomenon" - "a substance" lies in the basis of CLOUDS ARE WOOL metaphor in the Ukrainian translation. The nominal construction "вовна $x_{\text {мap" }}$ is built on the principle of subjectivity. The clouds are seen as soft substances creating the poetic illusion as if they were alive.

Byron's poetry often reveals fascination with the natural world. The poet writes perceptively of trees and flowers, oceans and rivers and uses lucid metaphors to describe the sky and the sea. This wonderful balance between imagination and observation is, in many ways, what makes Byron's verse the perfect hook for a life-long appreciation of poetry.

His nature poems divide into those that are chiefly presentations of scenes appreciated for their liveliness and beauty, and those in which aspects of nature are scrutinized for keys to the meaning of the universe and human life. The distinction is somewhat artificial but still useful, for it will encourage consideration of both the deeper significances in the more scenic poems and of the pictorial elements in the more philosophical poems. As we have noted, nature images and metaphors permeate Byron's poems on other subjects and some of those poems may be more concerned with nature than at first appears.

The personification of an atmospheric phenomenon is laid in the poetic image of wind in the Ukrainian translation.

SL "Stanzas For Music" There be none of Beauty's daughters With a magic like thee; And like music on the waters Is thy sweet voice to me: When, as if its sound were causing The charmed Ocean's pausing, The waves lie still and gleaming, And the lulled winds seem dreaming: And the midnight Moon is weaving Her bright chain o'er the deep; Whose breast is gently heaving. As an infant's asleep: So the spirit bows before thee, To listen and adore thee; With a full but soft emotion, Like the swell of Summer's ocean. 
TL “Станси під музику” Ніхто із донь краси земної Не збурює

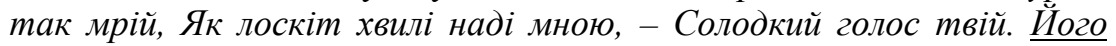
чарівний звук лунає, Приборкуючи моря гомін, I зоряний принишклий промінь На спині вітру засинає. I місяиь у сріблясті персні Хвилини засиля. I дихають світи небесні, Мов сонне немовля. Мій дух, мов райдуга до неба, Здіймається для тебе. Обожнюю, лечу до вирію В маю морською хвилею. (Translation by V. Bohuslavska)

The extended metaphor WIND IS A LIVING BEING THAT SINGS CRADLE SONGS is reconstructed in the Ukrainian translation under the strong influence of national folklore. The metaphorical concept is represented explicitly in the genitive construction "На спині вітру засинає". The latter is based on the principle of personification of the air. The predicative construction "Його чарівний звук лунає" explicates the meaning of a cradle song along which “моря гомін” and "принишклий промінь засинають". The poetic metaphor creates an illusion of nature similar to a human world.

Mixed feelings of a different kind are striking in Byron's many poems about storms with (and occasionally without) rain. The details of the scene are presented in a series of vigorous personifications and metaphors. The wind is rising and sweeping across the land. Its force makes some of the grass stand up high and some lie down. The description of leaves unhooking themselves and dust scooping itself animates the landscape and conveys a sense of excitement about the release of power. Lightning is a giant bird whose head and toe stand for its jagged sweep.

A POET IS A BIRD metaphor represents Byron's original association of himself with a bird: "A bird of free and careless wing Was I". In the Ukrainian translation this metaphor has been specified in a comparative construction: „О, як мені з душного світу Мов голуб до свого кубла У небо грозове злетіти". In this context a special attention should be paid to the image of the concept of SNARE in the original and ГНІЗДО in the translation. The poet calls himself " $a$ bird caught within the subtle snare", that is being associated with a bird, the author puts forward the meaning of losing his freedom, caused by love.

Birds putting up bars to nests humanize their actions and parallel the behavior of people. All the images of flight thus far, including the description of the landscape, build up a tension which begins to ease with the description of the drop of giant rain.

Byron's more philosophical nature poems tend to reflect darker moods than do his more descriptive poems and are often denser and harder to interpret. The nature scenes in these poems often are so deeply internalized in the speaker that a few critics deny the reality of their physical scenes 
and insist that the poems deal exclusively with states of mind. Despite their relative brevity, Byron's philosophical nature poems are often quite rich in meaning and connotation, and they can be re-read and reexperienced from many angles.

PEOPLE ARE PLANTS. In this metaphor, people are viewed as plants with respect to the life cycle - more precisely, they are viewed as that part of the plant that burgeons and then withers or declines, such as leaves, flowers, and fruit, though sometimes the whole plant is viewed as burgeoning and then declining, as with grass or trees.

The stages of the plants and parts of plants in their yearly cycle correspond to the stages in life. When we speak of someone as a "young sprout", we mean that he is in the early stages of life. Someone "in full bloom" is mature. Someone "withering away" is approaching death. Thus, in Byron's poetry we can apply the PEOPLE ARE PLANTS metaphor to read "Stanzas to Augusta":

SL "Stanzas to Augusta" Thou stood'st, as stands a lovely tree, That still unbroken, though gently bent, Still waves with fond fidelity Its boughs above a monument.

TL “Станси до Августи” Кохання деревцем гінким Обом нам зав'язало світ. Обоє ми - його гілки У вічності квітучих віт. (Translated by V. Bohuslavska)

The metaphoric image is created in the line with a fixed folklore association of love with a tree on the one hand "Кохання деревцем гінким Обом нам зав'язало світ", and a human being - on the other hand: “Обоє ми - його гілки У вічності квітучих віт”. A tree in blossom symbolizes a person in love, a specific harmony of man with the surrounding world.

TL "Stanzas to August" In the Desert a fountain is springing, In the wide waste there still is a tree, And a bird in the solitude singing, Which speaks to my spirit of Thee.

SL “Станси до Август” Джерельие у пустелі дивовижне, І солоспів самотній солов'я, $У$ спеку степову розквітлу вишню I звістку, щзо несе душа твоя. (Translated by D. Palamarchuk)

The poetic image of life in the desert is realized by means of a chain of metaphoric compositions, in which numerous elaborations and cognitive mechanisms of extensions have been made in the Ukrainian translation. Thus, an English "fountain" has been rendered as "джерельие”, a "treе" has been modified into "розквітлу вишню", and finally "a bird in the solitude singing” has been specified into “солоспів самотній солов'я”.

The same instances of modification of some basic concepts are observed in the following poem: 
TL “Stanzas for Music" Light be the turf of thy tomb! May its verdure like emeralds be! There should not be the shadow of gloom In aught that reminds us of thee. Young flowers and an evergreen tree May spring from the spot of thy rest: But nor cypress nor yew let us see; For why should we mourn for the blest?

SL “Станси під музику” Надгробок твій з промінних трав! Росу смарагдами гойдає. Тут морок дрібку світла вкрав, Яка про тебе нагадає. Весняні квіти, зелен-лист Твій відпочинок вкрили тінню. Та де верба, де кипарис? - Де виплачу благословення? (Translated by V. Bohuslavska)

Byron's "young flowers" have been substituted by "весняні квіти”, “an evergreen treе" has been rendered as“зелен-лист”. Moreover, there is a case of extension of a poetic image in the translation by adding a definite type of a tree: "But nor cypress nor yew let us see" - "Та де верба, де кunapuc?” A number of poems reveal that Byron regarded nature as being invested with symbolic and sacred meaning, indeed, that it could be the symbolic instrument of spirit, capable of conveying grace and assurance of spiritual regeneration.

\section{CONCLUSIONS}

The use of metaphor in poetry can hardly be avoided. First, it enables the author to squeeze multiple images and complex senses into a dense space due to the architectonics of a poetic genre. Second, metaphor can structure a verse itself. Metaphor can be described as figure of speech in which a thing is referred to as being something that it resembles. In this way, metaphors are used in poetry to explain and elucidate emotions, feelings, relationships other elements that could not be described in ordinary language. Poets also use metaphor as a mode of explaining or referring to something in a brief but effective way.

There is no simplistic general rule for the translation of metaphor, but the translatability of any given SL metaphor depends on 1) the particular cultural experiences and semantic associations exploited by it; and 2) the extent to which these can, or cannot, be reproduced non-anomalously into the TL, depending on the degree of overlap in each particular case.

What determines the translatability of a SL metaphor is not its "boldness" or "originality", but rather the extent to which the cultural experience and semantic associations on which it draws are shared by speakers of the particular TL. Moreover, the inherent difficulty of metaphor translation is not the absence of an equivalent lexical item in the TL, but rather the diversity of cultural conceptualization of even identical 
objects or worlds in both communities whose languages are involved in translation.

In the research done conceptual metaphors in Byron's original poetry and its Ukrainian translations have been studied from two perspectives. Firstly, the major modes of poetic metaphors elaboration have been examined. As it has been illustrated, poetic thought extends and elaborates conventionalized metaphors via the mechanisms of extending, elaborating, questioning, composing and personification. The latter mode is probably the most effective and frequently used in Byron's poetry since personification permits us to use our knowledge about ourselves to maximal effect, to use insights about ourselves to help us comprehend such things as forces of nature, common events, abstract concepts, and inanimate objects.

Secondly, in accordance with Mandelblit's "Cognitive Translation Hypothesis" poetic metaphors have been divided into two groups:

1) metaphors of similar mapping conditions but verbalized differently in the Ukrainian translations. Although Byron's original metaphors and their Ukrainian counterpart metaphors belong to the same conceptual domain, the ethnical and cultural system has led to major differences in lexical choices.

2) metaphors of different mapping conditions. This group includes cases of English poetic metaphors the image of which cannot be reproduced in the TL. Therefore, the translator has no choice other than replacing the SL image with a TL image that does not clash with the target culture. This can only be done by resorting to the strategy of different cognitive mapping in search for cognitive equivalence.

\section{SUMMARY}

The research is dedicated to the study of conceptual metaphors and modes of their elaboration in Byron's original poetry and its Ukrainian translations. It is firmly believed that basic conceptual metaphors reflect the universal principles of encoding human experience in language. In poetry conventional metaphors undergo the mechanisms of elaboration that extend the content of a correlating concept, illustrating culturally specified nature of metaphor. In a line with this the translation of conceptual metaphors proves to be heavily conditioned by culture aspect, embodied in a text with purposefully selected language means or images that accumulate national traditions and folklore. 


\section{REFERENCES}

1. Байрон Дж. Г. Лірика / Дж. Г. Байрон ; [упор. і пер. 3 англ. Д. Паламарчук]. К. : Дніпро, 1982. 150 с.

2. Байрон Дж. Г. Твори / Дж. Г. Байрон ; [пер. 3 англ. В. Богуславської]. К.: Дух і Літера, 2004. 366 с.

3. Кочур Г. Третє відлуння / Григорій Кочур. К. : Рада, 2000. C. 57.

4. Маслова В. А. Лингвокультурология: учеб. пособие / Валентина Авраамовна Маслова. М. : Академия, 2001. 204 с.

5. Ніконова В. Г. Реконструкція концептуальної метафори: ідентифікація концепту-кореляту (на матеріалі трагедій В. Шекспіра) / В. Г. Ніконова // Нова філологія: зб. наук. праць. Запоріжжя: ЗНУ, 2007. № 31. C. 41-44.

6. Опарина Е. О. Исследование метафоры в последней трети XX века / Е. О. Опарина // Лингвистические обзоры в конце XX века. М. : Институт языкознания РАН, 2000. С. 186-203.

7. Ясинецька О.А. Переклад метафори як мовна репрезентація концептуальних картин світу / О.А. Ясинецька // Філологічні трактати. 2010. Т. 2, № 1. Видавництво СумДУ. С. 96-100.

8. Byron G. Selections From Byron. Lyrical Verse / G. Byron. Moscow: Progress Publishers, 1979. 520 p.

9. Gibbs R. W. The Poetics of Mind: Figurative Thought, Language and Understanding / R. W. Gibbs. Cambridge: Cambridge University Press, 1999. 527 p.

10. Katan D. Translating Cultures: An Introduction for Translators, Interpreters and Mediators. Manchester: ST Jerome Publishing, 1999. 302 p.

11.Lacoff G. The Contemporary Theory of Metaphor / G. Lacoff // Metaphor and Thought / Ed. by Andrew Ortony. 2-nd edition. Cambridge: Cambridge University Press, 1993. P. 202-251.

12. Lacoff G., Johnson M. Metaphors We Live By / G. Lacoff, M. Johnson. Chicago: The University of Chicago Press, 1980. 240 p.

13. Lacoff G., Turner M. More than cool reason: a field guide to poetic metaphor / G. Lacoff, M. Turner. Chicago: University of Chicago Press, 1989. P. 16.

Newmark P. Approaches to Translation / Peter Newmark. Oxford: Pergamon Press, 1981. 230 p.

14. Mandelblit N. The Cognitive View of Metaphor and its Implications for Translation Theory. Translation and Meaning / N. Mandelblit. Maastricht : Universitaire Press, 1995. P. 483-495.

15. Newmark P. Approaches to Translation / Peter Newmark. Oxford : Pergamon Press, 1981. 200 p. 
16. Newmark P. The Translation of Metaphor / Peter Newmark // Babel, 16: 2. 1980. P. 93-100.

16. Nida E. Towards a Science of Translation / E. Nida. Leiden: E. J. Brill, 1964. 287 p.

17. Quinn N. The cultural basis of metaphor / N. Quinn // Beyond metaphor: the theory of tropes in anthropology. Stanford, 1991. P. 56-93.

\section{Information about the author:} Chendey N. V., Candidate of Philological Sciences in Comparative Linguistics, Associate Professor at the Department of English Philology, Uzhhorod National University 14, Universytetska str., Uzhhorod, 88000, Ukraine 


\section{ENGLISH AND SLOVAK LANGUAGE SYSTEMS IN CONTACT: SUPRASEGMENTAL LEVEL}

\section{Devitska A. I.}

\section{INTRODUCTION}

Current state of formation of national and territorial variants of English, known as New Englishes and World Englishes, is caused by the phenomenon of globalization of English in the world ${ }^{1}$. Each of these variants forms a social and communicative system designed to provide communication of its speakers ${ }^{2}$. The term "non-English speakers" defines the category of the speakers who speak and use English but their native language is the other.

The need for the term "non-English speakers" is due to the emergence of New Englishes (World Englishes), and is proved by the existence in modern linguistics the terms Native speakers (NS) and Non-native speakers $(N N S)^{3}$.

Considering the typology of English language variants, the researcher B. Kachru proposed a classification of the variants and the idea of globe separation into three regions of English proficiency ("Kachru Circles"). The first circle, called the Inner circle, includes the countries where English is the native language; the second circle (Outer or Extended circle) includes those countries where English is the second language; third circle (Expanded circle) comprises the countries where English is spoken as a foreign language. B. Kachru suggests that boundaries between these circles are constantly changing in the direction of increasing due to the influence of the English language.

A broader perspective has been adopted by D. Crystal, who used in his works a similar scheme to describe the languages and language processes that take place. It is quite natural that the newly created English versions retain the features of the British and American variants, however, each of them has its own cultural and linguistic features.

\footnotetext{
${ }^{1}$ Kang O. Learners' perceptions toward pronunciation instruction in three circles of World Englishes. TESOL Journal. 2015. Vol. 6(1). P. 59-80. doi: 10.1002/tesj.146, http://dx.doi.org/ 10.1002/tesj.146.

${ }^{2}$ Kachru B. Standards, codification and sociolinguistic realism : the English Language in the Outer Circle. English in the World. Cambridge : Cambridge University Press, 1998. P. 11-34.

${ }^{3}$ Toivanen J. Tone of Choice in the English Intonation of Proficient Non-native Speakers. Phonum. 2003. Vol. 9. P. 165-168.
} 
The expansion tendency circle covers English as a foreign language for intercultural communication of representatives of different ethnicities, for example, Spanglish - Spanish English, Ukrainglish - Ukrainian English, Runglish - Russian English, Polglish - Polish English, Chenglish - Czech English, Chinglish - Chinese English, Japtish Japanese English, Slovglish - Slovak English, etc.

In the same vein, Esther Low suggests a slightly different pattern of distribution of these circles: the contours of the "outer circle" interact with the contours of the "expanding circle", thus reflecting the probability of linguistic contacts between the speakers of the respective circles in the process of intercultural communication ${ }^{4}$.

Drawing on an extensive range of sources, the authors set out the different ways in which they note that circles' formation is different from the development of postcolonial English, that is, an "external" circle, since English in Europe functions as a means of communication ${ }^{5}$. Being fluent in English, Europeans do not identify themselves with the English-speaking culture that countries from the "outer" circle aspire to. Overall, these cases support the view that, English in Europe is not a matter of prestige, but convenient, due to its versatility, tool of international communication.

One of the most up-to-date theories that reflects language contacts is considered to be so-called "networking" developed by E. Thomas ${ }^{6}$. According to the theory, the language tree has many branches, and it reflects the presence of multiple horizontal links between different language variants, which facilitates the transfer of language features and phonetic interference between language variants at different stages of its development. Considering all the difficulties of multilateral contacts, which have resulted in the emergence of new national-English variants of the English language, a network scheme containing a description of the individual variants and their interaction seems to be the most thorough.

It is important to note that one of the relatively recent English language versions is rightly considered to be Euro-English or European English language version. Particularly, scientists' attention is drawn to Euro speak or European Lingua Franca, ELF (European Lingua franca) and its unique characteristics $^{7}$. The debate has gained fresh prominence with many

${ }^{4}$ Low E. L. The Acoustic reality of the Kachruvian Circles. World Englishes. 2012. Vol. 29(3). P. 394-405.

${ }^{5}$ Hall G., Cook G. The English language needs and priorities of young adults in the European Union: student and teacher perceptions. ELT Research Papers 15.01. British Council, 2015. 65 p.

${ }^{6}$ Thomas E. Sociophonetics. An Introduction. Basingstoke. New York : Palgrave Macmillan, 2011. 272 p.

7 Salakhyan, E. The emergence of Eastern European English. World Englishes. 2012. P. 331-350. doi: 10.1111/j.1467-971X.2012.01755. 
arguing that Euro-English is a variant of English, serving as a lingua franca for continental European countries. It is evident that a distinctive feature of Euro-English is that it is originated in an environment of educated Europeans as a means of intercultural communication in the framework of negotiations, scientific conferences, telecommunications and business projects, and it has become an intercultural heritage, designed to activate the communicative processes in European languages and cultures.

In the pages that follow, it will be argued that, Euro-English variants of English nowadays create a special interlingua environment encompassing the "hybrid space" of intercultural communication, and reflect a "third culture" that promotes the unification of European multilingualism and multiculturalism in the context of the English language. Mainly, the recognition of Euro-English as a means of international communication to enhance communication among diverse cultures driven by the need of time but not by the matter of prestige, but by the need to accurately convey the contexts in the close inter-ethnic communication of a united Europe.

Recent research has suggested that the creation of the above mentioned variants of European English takes place in the context of mutual intercultural influence and linguistic contacts ${ }^{8}$. Thus, the standard British Pronunciation (RP) is also affected by the languages which are in contact. This process can be explained by extra linguistic factors such as the emergence of new realities related to the emigrant culture and the need for their nomination and acculturation.

The theory of language contacts was proposed by W. Weinreich ${ }^{9}$ in 1953 to identify the links between social and linguistic factors, although the study of language contacts began in the late 19th century in the works of L. Shcherba ${ }^{10}$. Subsequently, this concept was developed in numerous works of modern linguists Yu. Zhluktenko ${ }^{11}$, O. Semenets ${ }^{12}$, S.V. Semchinsky $^{13}$ and other researchers. The study of language contacts has become an independent field in linguistics. According to some researchers, a new field in modern linguistics is forming "linguistics of language contacts" (contact linguistics).

${ }^{8}$ Sebba M., Mahootian Sh., Jonsson C. Language Mixing and Code-Switching 67 in Writing; Approaches to Mixed-Language Written Discourse. Routledge, UK, 2012. P. 22-29.

${ }^{9}$ Weinreich U. Languages in Contact. The Hague : Mouton, 1968. 411 p.

${ }^{10}$ Щерба Л. В. Языковая система и речевая деятельность. Москва : Едиториал УРСС, 2004. $432 \mathrm{c}$.

${ }^{11}$ Жлуктенко Ю. О. Мовні контакти. Проблеми інтерлінгвістики. Київ, 1966. 134 с.

${ }^{12}$ Семенець О .Є. Соціолінгвістична типологія варіантів поліетнічної мови. Мовознавство. 1986. № 2. С. 8-14.

${ }^{13}$ Семчинський С. В. Загальне мовознавство. Київ : АТ «ОКО», 1996. 416 с. 
As languages interact and enrich each other, language contacts reflect interaction and enrichment not only in the material and spiritual cultures of different people, the historical contacts between them, but also represent an extremely complex and multilevel process, which reflects the development of modern society. As a result, the linguistic term "language contacts" has become widespread in the field of sociolinguistic research to indicate the processes and results of socially mediated interaction of languages. Because of this, the language changes that have taken place have been investigated in contact languages due to external factors.

It has commonly been assumed that, the theory of language contacts has acquired the ability to reflect the main problems of language interaction, to identify the general and specific in this language phenomenon, to outline the basic concepts that contribute to the study of individual cases of language contact, to identify the general patterns of the process under study.

Another important point is a number of debates that prevail over the definition of the term "language contact", one of which is the multivariate name of the term: linguistic contact, interlingua contacts, linguistic interaction, interaction of languages, languages mixing, mutual influence of languages, interference, code-switching, borrowing, hybridization. Differences in the definition of the term "linguistic contact" are due to the fact that the researchers name the same concept differently; second, the variety of terminology is driven by methodology and the purpose of the study; another point is, there are numerous aspects of study of this issue: sociolinguistics, psycholinguistics, linguistics.

According to the concept of E. Haugen, the term "language contact" refers to the "alternate use of two or more languages by the same person", while the researcher does not specify either the level of language proficiency, or the conditions of their use or the degree of difference between language ${ }^{14}$. O. Akhmanova explains the meaning of "linguistic contact" as "a collision of languages that arises because of particular geographical, historical or social conditions that necessitate the linguistic communication of societies speaking different languages"15.

In contrast, Yu. Zhluktenko proposes the use of the term "language interaction", which has a broader interpretation and encompasses "the total dynamic processes that cause the transfer, copying or loss of units and models that stimulate or stop certain trends and processes created in the

\footnotetext{
${ }^{14}$ Хауген Э. Языковой контакт. Новое в зарубежной лингвистике. Москва : Прогресс, 1972. Вып. VI: Языковые контакты. С. 61-81.

15 Ахманова О. С., Минаева Л. В. Место звучащей речи в науке о языке. Вопросы языкознания. 1977. № 6. С. 44-50.
} 
language system, and cause the mutual imposition of differential features, interaction of articulatory and prosodic characteristics, and other areas" ${ }^{16}$. S. Semchynskyy divides the factors that cause the appearance of language contacts into several groups: extra-linguistic (historical and geographical, social and political, cultural, psychological and other areas), linguistic (genetic community, grammatical structure of languages) ${ }^{17}$. It can be concluded that each of these factors of language contacts is capable of influencing the development of languages in contact: mixing languages or absorbing one language into another as well as forming numerous language unions.

Another main criterion for the typology of language contacts developed by Yu. Zhluktenko is their duration and stability. According to this classification, all language contacts can be causal, that is, temporary, or permanent. M. Kocherhan distinguishes between the following types of linguistic contacts: direct and indirect; between related and unrelated languages; with one-sided and mutual influence; marginal (on adjacent territories) and inland (within the same territory); causal and permanent; natural (direct communication), artificial (schooling) and mixed (natural and artificial $)^{18}$.

Based on this typology of language contacts, Slovak language interaction with English language system in Slovakia can be classified as a direct, related language, intra-regional, permanent, natural and artificial, whereas mutual influence of Slovak-English language contacts in the United Kingdom as causal, permanent and natural. As a consequence, such Slovak-English language contacts contribute to the emergence of a variety of linguistic phenomena. Thus, in some cases, they lead to borrowings and various types of linguistic interference, in others the convergent development of interacting languages, "code switching", and linguistic assimilation can be observed ${ }^{19}$.

J. Fishman ${ }^{20}$ identifies four stages of the process of linguistic assimilation characteristics of immigrants. According to his theory, the first stage of English language acquisition is mainly done by native language. In situations where the use of the mother tongue is impossible, mainly when communicating in public institutions, at work and other areas

${ }^{16}$ Жлуктенко Ю. А. Лингвистические аспекты двуязычия. Київ, 1974. 176 с.

${ }^{17}$ Семчинський С. В. Семантична інтерференція мов. Київ : Вища школа, 1974. 256 с.

${ }^{18}$ Кочерган, М. П. (2006). Основи зіставного мовознавства: Підручник. Київ: Видавничий центр «Академія».

${ }^{19}$ Гавранек, Б. К. (1972). К проблеме смешения языков. Новое в лингвистике: Языковые контакты, VI, 94-107. Москва: Прогресс.

${ }^{20}$ Fishman, J.A. (2003). Bilingualism With and Without Diglossia; Diglossia With and Without Bilingualism. Sociolinguistics: the Essential Readings. Oxford: Blackwell Publishing. 
the immigrant speaks mostly English. Thus, at this stage the interference from the English language is minimal, since the level of immigrant's English language proficiency is low and the number of people who speak it is small. The second stage of language assimilation tends to increase both the number of English-speaking immigrants and the degree of its mastering. Because English is spoken in the United Kingdom, unlike Slovak, it is used in more communication spheres, so it is possible to follow the process of linguistic interference, as a result of Slovak-English language contacts' interaction, particularly at suprasegmental level.

Finally, independent functioning of English and Slovak is observed on the third stage. It is the process of linguistic assimilation that characterizes English speech of the Slovaks who emigrated to the United Kingdom. Naturally, the total number of immigrants who speak English at this stage is the biggest. At the same time, there is a maximum blending of English and Slovak languages in different areas of communication. The final stage of language assimilation includes the removal or replacement of one's native language (Slovak) by English from all spheres of communication.

In the context of the usage of English and Slovak languages, the researchers distinguish such basic types of communication environments as family circle, study, work, travel and other areas. ${ }^{21}$ However, the Slovaks who live in the UK, can use Slovak mainly in their family, that is, in a limited social environment, or during annual meetings of foreign Slovaks, at seminars, congresses, conferences or festivals, organized in other EU countries.

\section{Prosodic characteristics of English and Slovak languages}

Prosodic characteristics of speech play a decisive role in speech making, as well as its linguistic and communicative function. The study of prosodic characteristics of English speech of the Slovaks is extremely relevant to linguists, since in comparison with the lexical and grammatical aspects of the language, phonetic changes take place much faster.

Prosody has long been a question of great interest in a wide range of fields. The focus of modern linguistic research is directed to the study of the role of prosody while conveying the meaning, that is, not only common models of realization, but also the limits of variability of prosodic characteristics while creating variants of linguistic combinations are revealed. The description of the prosodic characteristics of any language is traditionally considered to be a difficult task, since prosody is, on the one

\footnotetext{
${ }^{21}$ Pokrivcáková S. (2013). Bilingual education in Slovakia: a case study. Journal of Arts and Humanities 2.5 (Jun 2013), 10-19.
} 
hand, the most universal feature of speech, and on the other, it reflects the unique and specific features that can be found in the suprasegmental level of each language.

Violations in the prosody of English speech of the Slovaks are due to the influence of the prosodic system and intonation skills in native language, to an insufficient degree of command of a foreign language as well as extra linguistic factors. The acoustic parameters of voice such as tone, rate of speech, timbre play a leading role in forming the perception of the speaker's personality ${ }^{22}$. Native speaker defines the speaker's belonging to another linguistic community, first and foremost by the nature of his pronunciation, that is, the particular phonetic coloration of the speech caused by the interfering influence of the phonetics of the native language.

A review of theoretical and experimental studies has led to the conclusion that the concept of prosody is to be interpreted as a complex of tonal, temporal, dynamic, timbre parameters, which at the perceptual level are perceived as melody of speech, rhythm, tempo, timbre, pausing, volume $^{23}$. The prosodic characteristics of the English-language text are interpreted as a set of suprasegmental units of speech that form the basis of intonation constructions and convey linguistic meanings. The speech signal, which contains the information about the emotional state of a person at the moment of communication is very important as well. Some linguists have devoted a number of scientific works to the study of the variability of intonational parameters of speech depending on emotional state $^{24}$.

English language melody is considered to be a major component of the intonation system and is implemented by raising or lowering the volume ${ }^{25}$. The composition of the melody includes: tone level, range, interval, speed. Also, voice modulation or variation of melody, quality, intensity and duration influence the process of conveying the meaning and indicate individual characteristics of the speaker, such as his gender, age and emotional state. In addition, melody conveys a considerable amount of extra linguistic information about the speaker's emotional state, such as whether he is calm, angry, happy, exhausted, anxious, frustrated or sad ${ }^{26}$. In English

22 Калита А. А. Система фонетичних засобів актуалізації смислу висловлювання (експериментально-фонетичне дослідження англійського емоційного мовлення): дис ... д-ра філол. наук: спец. 10.02.04. Київ, 2003. 566 с.

${ }^{23}$ Cruttenden A. Intonation. Cambridge: Cambridge University Press, 2001.

${ }^{24}$ Brazil D. The Communicative Value of Intonation in English. Cambridge: Cambridge University Press, 1997.

${ }^{25}$ Roach P. English Phonetics and Phonology. A practical course. Cambridge: Cambridge University Press, 2001.

${ }^{26}$ Crystal D. A Dictionary of Linguistics and Phonetics. Oxford: Blackwell Publishers, 2000. 
language, the changes of the melody convey linguistic information about the syntactic components of the expression, provide lexical information about the meaning of the word and its grammatical function. The melody, that is intonation of the Slovak language is divided into three main types of melody in the statement: falling, rising, and half-falling ${ }^{27}$.

In Slovak language, the stress is dynamic, whereas the word stress is fixed on the first syllable, for example, Pozajtra sa s Vami stretneme. Primary and secondary stresses are to be differentiated also. It should be noted that primary stress in Slovak is clearly observed in compound words, which are to be pronounced in a slower tempo, for instance, polovodič [|pololvodič], polnohospodár [|polnolhospodár], spolupráca [|spolulpráca], vel'koobchod [|vel'kolopxot], where upper vertical line indicates primary stress and the lower one indicates the secondary. Consequently, the dominance of the stressed syllable over unstressed in Slovak language results its rhythmic organization ${ }^{28}$.

Areas where significant differences have been found include word stress. Slovak language is characterized by a fixed stress on the first syllable, signaling only about the beginning of words, since it does not change the meaning of the word unlike English ${ }^{29}$. However, there are also some boundary connections, in which the stress appears to be a decisive prosodic feature and promotes better understanding of meaning perception. Thus, the stress in Slovak language has an important delimitative function, since it emphasizes the word and its boundaries, and becomes a basic rhythmic and semantic unit ${ }^{30}$.

In the same way, word meaning in Slovak is changed by means of vowel lengthening, whereas vowel lengthening does not transmit the stress, it remains on the first syllable. It is important to note that all vowels and endings in Slovak should be pronounced clearly, without slurring the endings. Another distinctive feature of Slovak language is also stressed prepositions, as they can be both stressed and unstressed. Phrase stress as a component of intonation both in English, and in Slovak, serves to highlight the most semantically important word in a statement or its part, it can completely change the meaning of a word, giving it positive or negative connotations, signalizing the psycho physiological features of the speaker and his sociocultural status.

${ }^{27}$ Beňuš Š., Šimko J. Rhythm and tempo in Slovak. Proceedings of the 6th International Conference on Speech Prosody. Chicago, 2012. P. 502-505.

${ }^{28}$ Ibid.

${ }^{29}$ Sabol J. Rytmická stavba reči. In: K. Buzássyová (Red.). Človek a jeho jazyk. 1. Jazyk ako fenomén kultúry. Na počest’ profesora Jána Horeckého. Bratislava: Veda, 2000. P. 319-327.

${ }^{30}$ Ibid. P. 322. 
The completeness of thought, depending on the communicative type of expression, is created by the final tone decrease or increase, which cause an auditory impression of logical emphasis, that is, the semantic completeness of expression is created, first of all, by means of intonation.

J. Sabol and Yu. Zimmermann point out that melody, syllable length and intensity are the stress correlates in Slovak language ${ }^{31}$. D. Fry concluded from experimental studies that melody plays the main role in English language, the second place makes syllable length, whereas intensity is on the third ${ }^{32}$. However, in spite of a number of common features, there are also distinctive ones, such as the reduction of vocalism in Slovak language which does not occur in the same amount as in English.

Melody contour of the Slovak language as a component of melody or as a separate component of its subsystem may be level, descending or ascending, and may also have a complex form, such as descendingascending, ascending-descending or ascending-descending-ascending. Thus, these models of meaningful tone directions in intonation groups or in whole expressions perform the function of distinguishing the semantics of the same expression ${ }^{33}$.

As for the broad tonal range both in Slovak and English languages, it is associated with excited or passionate speech. The most commonly used type of melody contour in Slovak is considered to be descending and ascending, while in English it is descending and descending-ascending. Consequently, the melody of Slovak literary language is characterized by its rising variation, whereas the English one has falling.

The alternation of stressed and unstressed syllables makes the basis of the rhythm in Slovak language, as well as timing and melody components. The configuration of stressed and unstressed syllables creates a primary rhythmic wave of speech that is the movement from composition to beat. The secondary rhythmic flow is the movement from beat to the sentence ${ }^{34}$. Thus, English speech of the Slovaks will be different from the standard British variant of pronunciation because the difference in stressed and

${ }^{31}$ Sabol J., Zimmermann J. On the Problem of the Stress in Literary Slovak. In: Z. Palková (Red), Acta Universitatis Carolinae. Philologica. 1. Phonetica Pragensia. 9. Charisteria viro doctissimo Přemysl Janota oblata. Prague, Karolinum, Charles University Press, 1996. P. 245-250.

${ }^{32}$ Fry D. B. Duration and intensity as physical correlates of linguistic stress. Journal of the Acoustical Society of America. 1955. Vol. 27. P. 765-768.

${ }^{33}$ Sawicka I. An Outline of the Phonetic Typology of the Slavic Languages. Torun: Wydawnictwo Uniwersytetu M. Kopernika, 2001.

34 Eddy E. Správna výslovnost': Základ efektívneho dorozumenia. In Z. Straková, I. Cimermanová (Eds.). Učitel' cudzieho jazyka v kontexte primárneho vzdelávania (rozšírené vydanie). Prešov: Prešovská univerzita, 2013. 
unstressed syllable length in their speech will not have the maximum rate as native English speakers have.

Tempo in Slovak language is a suprasegmental phenomenon that depends from the speed of articulation of separate vowels, combined with syllables in speech. J. Sabol in his monograph "Intonation of Slovak Literature Language" distinguishes between the use of slow and fast tempo $^{35}$. According to his definition, tempo serves as a sensitive indicator during articulatory and acoustic, perceptual realization, and also depends from the speed of objective reality emphasis by means of language and the speaker's response to a specific and immediate situation.

Tempo is also one of the main signals and regulators of the semantic component of the speech, that is, the greater the semantic manifestation is, the slower the tempo and vice versa. In addition, the characteristic feature of English and Slovak languages is that the completion of the utterance is often signaled by the slowing of articulation speed of its last part, by which the listener is encouraged to communicate.

Regarding the characteristic features of pauses in Slovak language, they are divided into two types: physiological and logical (determining) ${ }^{36}$. Physiological one appears for breathing purposes, while logical is considered a language pause and is used to separate relatively independent and semantic utterances, to construct a hierarchy of spoken units. Pauses in Slovak language can be found in: 1) the boundaries of independent sentences, separated by full stop, question mark, or exclamation mark, for example, Srdce jej išlo puknút'.|Z neopätovanej lásky?|Ale kdeže! ||Bol som si istý, |že ked'splniš všetky podmienky, |stane sa z teba vítaz celej sút’aže. \|; 2) in longer utterances:|| V malej dedinke pod horami |v jedno slnečné ráno|vybral sa susedovie Janko|na rol’u otcovi pomáhat'.| 3) direct speech: || „Mal som z toho poriadny šok,“| povedal profesor podráždene. || Also, creative pauses while reporting unexpected facts, transmitting certain emotions can be found in Slovak language ${ }^{37}$.

Suprasegmental (prosodic) features, such as phrase stress, intonation, speech tempo, pauses and rhythm in Slovak language play a crucial role in transmitting the subjective attitude of the speaker to the utterance, as well

\footnotetext{
${ }^{35}$ Sabol J. Intonácia spisovnej slovenčiny. Slovakistické štúdie: zborník vybraných prednášok Letného seminára slovenského jazyka a kultúry SAS. Red. J. Mistrík. Martin: Matica slovenská, 1985. S. 465-470.

${ }^{36}$ Sabol J. Rytmická stavba reči. In: K. Buzássyová (Red.). Človek a jeho jazyk. 1. Jazyk ako fenomén kultúry. Na počest’ profesora Jána Horeckého. Bratislava: Veda, 2000. P. 319-327.

37 Kral Á. Pravidlá slovenskej výslovnosti. 2. vyd. Bratislava: Slovenské pedagogické nakladatel'stvo, 1988.
} 
as in the actual and the rhythmic division of the sentence ${ }^{38}$. In fact, affirmative sentences and sentences beginning with an interrogative pronoun have a falling intonation, whereas, in interrogative sentences without interrogative pronoun rising intonation is observed.

Therefore some particular suprasegmental features that characterize the intonation the Slovak sentence can be observed: strong phrasal stress, broad tone interval, the speaker's desire to make each word significant, monotonous final beat melody, word emphasis is accomplished by syllable lengthening or the dynamic strengthening of the preceding syllable, stressed syllables' lengthening. The tonal, temporal and rhythmic organization of the phrase make it possible to detect intonation interference as a consequence of bilingualism.

The data of the analysis made, make it possible to conclude on the prosodic characteristics of English and Slovak languages. Each of the components of intonation has some meaning in English speech of the Slovaks. As a result of phonetic interference, speech accent appears, manifesting itself as a deviation from the English pronunciation standard (RP).

English speech of the Slovaks also reflects ethnical and specific characteristics of the primary language (mother tongue), which is mainly due to the complex ratio of articulation bases of native and foreign languages, and also contains a number of extra linguistic factors such as language competence, language ability, psychological type of the speaker, his/her social status as well as speech situation and other areas. Since melodic intervals (that is the difference in pitch frequency variation) are characterized by their increase in English, English speech is perceived by Slovaks as more singing and melodic than their mother tongue. Trying to imitate English language standard, Slovaks try to intonate clearly, and sometimes hyperbolize their pronunciation for better perception of their speech by native speakers ${ }^{39}$.

Thus, the study of the prosodic characteristics of English and Slovak languages allows us to assert that at the suprasegmental level, the analyzed prosodic characteristics of the Slovak language are often transferred into English. Consequently, it hinders the perception of English by the Slovaks as well as influences the quality of their English speech.

38 Bilá M. Duration of Pauses in Slovak and L1 Speaker's Productions of English. A Preliminary Investigation. $6^{\text {th }}$ Conference on British, American and Canadian Studies. Conference Proceedings. Opava, Czech Republic, 2000.

${ }^{39}$ Kral'ová Z. The correlation of extraversion and L2 pronunciation quality. In: Current issues in teaching foreign languages. Brno: Masarykova univerzita, 2011. P. 162-191. ISBN 978-80210-5608-4.

28 


\section{Phonetic interference in English Speech of the Slovaks}

The concept of language interference is central in the theory of language contacts and in bilingualism theory. Since the condition of language interference appearance is a situation of bilingualism, the bilinguals' speech is the place of its formation ${ }^{40}$.

For the first time in linguistics, the term "language interference" was used by the representative of Prague Linguistic School G. Vogt, who defined interference as a process of deviation from the standards in contact languages ${ }^{41}$. However, S. Semchynsky observes that the term primarily was used by A. Maye in the course of general lexicology ${ }^{42}$. Therefore, the term "interference" was acquired by A. Maye, but was widely recognized only after the publication of $\mathrm{W}$. Weinreich's monograph "Language contacts" $^{43}$.

The definition of language interference proposed by W. Weinreich is still generally accepted, but at different times attempts have been made to clarify it. The phenomena of language interference are, according to $\mathrm{W}$. Weinreich, those cases of deviation from the standard of any of the languages that take place in bilinguals' speech as a result of mastering more than one language, that is, through language contact.

The type of language interference, or its lack thereof, marks the degree of foreign language mastery, as well as the degree of correctness / incorrectness of the meaning convey in a foreign language as well as the degree of influence of the mother tongue ${ }^{44}$. The unit of measurement of different degrees of language interference is considered to be interpheme. Up to now, far too little attention has been paid to intonation interphemes in English spoken by Slovaks.

Among the features of linguistic interference Yu. Zhluktenko distinguishes the use of "foreign" language material in the context of mother tongue, the formation of units from own linguistic material as the model of the language units in contact, stimulating or delaying the effects of language complex units on the functioning of units or models of another one, copying models of one system by means of another system ${ }^{45}$. Thus, while studying language interference, the correlation of structures is analyzed as well as their mutual influence and interaction.

${ }^{40}$ Valian V. Bilingualism and Cognition. Bilingualism. Language and Cognition. 2015. Vol. 18(1). P. 3-24.

${ }^{41}$ Vogt H. Language contact. Word. 1954. Vol. 10(2-3). P. 365-374.

${ }^{42}$ Семчинський С. В. Семантична інтерференція мов. Київ: Вища школа, 1974. 256 с.

${ }^{43}$ Weinreich U. Languages in Contact. The Hague : Mouton, 1968. 411 p.

${ }^{44}$ Валігура О. Фонетична інтерференція в англійському мовленні українських білінгвів : монографія. Тернопіль : Підручники і посібники, 2008. 288 с.

45 Жлуктенко Ю. А. Лингвистические аспекты двуязычия. Київ, 1974. 176 с. 
The term "phonetic interference" is used here to refer to violation of the secondary language system and its norms as a result of interaction in the speaker's consciousness the phonetic systems and norms of pronunciation of two and more languages. This process is observed through the interference of listening and speaking skills formed on the basis of the interacting systems. Phonetic interference cases are possible when elements of a foreign language are absent or different in native language.

During phonetic interference, the speaker encounters a range of problems in the use of these languages, the perception and analysis of speech. Phonetic interference can influence thought formation about the speaker. Also, the native speaker can identify belonging of the speaker to a particular language community, assess the correct use of linguistic norms and the degree of compliance with the norms.

\section{CONCLUSIONS}

The process of mastering English pronunciation by Slovaks involves learning the skills of both sensory differentiation of non-native language sounds in the perception of oral speech, and motor differentiation of sounds during speech production. Mutual influence of English and Slovak language systems can occur at different stages of speech production as well as at the level of perception. Intercultural communication of the Slovaks is a form of communication, in which the ways of realization of different situations by the representatives of many cultures are not identical, that is, there are differences in their implementation and interpretation. It is important to take into account the specificities of the process of intercultural communication in order to prevent misunderstandings and conflicts when communicating with representatives of different linguistic and cultural communities in both English and Slovak languages.

English speech of the Slovaks as a result of interaction of language contacts in Slovakia and the United Kingdom is considered as interaction of universal, native to any native speaker, and national specific features formed under the influence of the phonetic system of the mother tongue.

\section{SUMMARY}

The study deals with the comprehensive study of prosodic characteristics of English Speech of the Slovaks and the identification of phonetic interference features. On the basis of existing theoretical and experimental works on the study of English speech of the Slovaks, we have qualified it as an interfered English speech formed as a result of the interaction of phonetic systems of the English and Slovak languages. 
The study of English Speech of the Slovaks had a phased nature. The first stage is devoted to the study of the theoretical foundations of the prosodic characteristics of English Speech of the Slovaks, the analysis of some pronunciation peculiarities, the description of prosodic characteristics of English and Slovak languages.

The experimental research outcomes have shown that the specificity of English pronunciation of the Slovaks at the suprasegmental level is generated by the unconscious transfer of stable phonetic patterns of their native language into the structure of the second language. Thus, English pronunciation of the Slovaks forms national and specific features of the primary language, which are clearly manifested in the rhythmic organization of an oral expression and reflect the influence of the intonation skills of the speakers' native language. The phonetic interference features in English Speech of the Slovaks are found in rhythmic law transfer, as well as the tradition to stress all words in the utterance.

\section{REFERENCES}

1. Ахманова О. С., Минаева Л. В. Место звучащей речи в науке о языке. Вопросы языкознания. 1977. № 6. С. 44-50.

2. Валігура О. Фонетична інтерференція в англійському мовленні українських білінгвів: монографія. Тернопіль: Підручники і посібники, 2008. 288 с.

3. Гавранек, Б. К. (1972). К проблеме смешения языков. Новое в лингвистике: Языковые контакты, VI, 94-107. Москва: Прогресс.

4. Жлуктенко Ю. А. Лингвистические аспекты двуязычия. Київ, 1974. 176 с.

5. Жлуктенко Ю. О. Мовні контакти. Проблеми інтерлінгвістики. Київ, 1966. 134 с.

6. Калита А. А. Система фонетичних засобів актуалізації смислу висловлювання (експериментально-фонетичне дослідження англійського емоційного мовлення): дис ... д-ра філол. наук: спец. 10.02.04. Київ, 2003. 566 с.

7. Кочерган, М. П. (2006). Основи зіставного мовознавства: Підручник. Київ: Видавничий центр «Академія».

8. Семенець О .С. Соціолінгвістична типологія варіантів поліетнічної мови. Мовознавство. 1986. № 2. С. 8-14.

9. Семчинський С. В. Загальне мовознавство. Київ : АТ «ОКО», 1996. $416 \mathrm{c}$.

10. Семчинський С. В. Семантична інтерференція мов. Київ : Вища школа, 1974. 256 с. 
11. Хауген Э. Языковой контакт. Новое в зарубежной лингвистике. Москва : Прогресс, 1972. Вып. VI: Языковые контакты. С. 61-81.

12. Щерба Л. В. Языковая система и речевая деятельность. Москва : Едиториал УРСС, 2004. 432 с.

13. Beňuš Š., Šimko J. Rhythm and tempo in Slovak. Proceedings of the 6th International Conference on Speech Prosody. Chicago, 2012. P. 502-505.

14. Bilá M. Duration of Pauses in Slovak and L1 Speaker's Productions of English. A Preliminary Investigation. $6^{\text {th }}$ Conference on British, American and Canadian Studies. Conference Proceedings. Opava, Czech Republic, 2000.

15. Brazil D. The Communicative Value of Intonation in English. Cambridge: Cambridge University Press, 1997.

16. Cruttenden A. Intonation. Cambridge: Cambridge University Press, 2001.

17. Crystal D. A Dictionary of Linguistics and Phonetics. Oxford: Blackwell Publishers, 2000.

18. Eddy E. Správna výslovnost': Základ efektívneho dorozumenia. In Z. Straková, I. Cimermanová (Eds.). Učitel' cudzieho jazyka v kontexte primárneho vzdelávania (rozšírené vydanie). Prešov: Prešovská univerzita, 2013.

19. Fishman, J. A. (2003). Bilingualism With and Without Diglossia; Diglossia With and Without Bilingualism. Sociolinguistics: the Essential Readings. Oxford: Blackwell Publishing.

20. Fry D. B. Duration and intensity as physical correlates of linguistic stress. Journal of the Acoustical Society of America. 1955. Vol. 27. P. 765-768.

21. Hall G., Cook G. The English language needs and priorities of young adults in the European Union: student and teacher perceptions. ELT Research Papers 15.01. British Council, 2015. 65 p.

22. Kachru B. Standards, codification and sociolinguistic realism : the English Language in the Outer Circle. English in the World. Cambridge : Cambridge University Press, 1998. P. 11-34.

23. Kang O. Learners' perceptions toward pronunciation instruction in three circles of World Englishes. TESOL Journal. 2015. Vol. 6(1). P. 59-80. doi: 10.1002/tesj.146, http://dx.doi.org/10.1002/tesj.146.

24.Kral Á. Pravidlá slovenskej výslovnosti. 2. vyd. Bratislava: Slovenské pedagogické nakladatel'stvo, 1988.

25. Kral'ová Zdena. The correlation of extraversion and L2 pronunciation quality. In: Current issues in teaching foreign languages. Brno: Masarykova univerzita, 2011. P. 162-191. ISBN 978-80-210-5608-4.

26. Low E. L. The Acoustic reality of the Kachruvian Circles. World Englishes. 2012. Vol. 29(3). P. 394-405. 
27. Pokrivcáková S. (2013). Bilingual education in Slovakia: a case study. Journal of Arts and Humanities 2.5 (Jun 2013), 10-19.

28. Roach P. English Phonetics and Phonology. A practical course. Cambridge: Cambridge University Press, 2001.

29. Sabol J. Intonácia spisovnej slovenčiny. Slovakistické štúdie: zborník vybraných prednášok Letného seminára slovenského jazyka a kultúry SAS. Red. J. Mistrík. Martin: Matica slovenská, 1985. S. 465-470.

30. Sabol J. Rytmická stavba reči. In: K. Buzássyová (Red.). Človek a jeho jazyk. 1. Jazyk ako fenomén kultúry. Na počest' profesora Jána Horeckého. Bratislava: Veda, 2000. P. 319-327.

31. Sabol J., Zimmermann J. On the Problem of the Stress in Literary Slovak. In: Z. Palková (Red), Acta Universitatis Carolinae. Philologica. 1. Phonetica Pragensia. 9. Charisteria viro doctissimo Přemysl Janota oblata. Prague, Karolinum, Charles University Press, 1996. P. 245-250.

32. Salakhyan, E. The emergence of Eastern European English. World Englishes. 2012. P. 331-350. doi: 10.1111/j.1467-971X.2012.01755.

33. Sawicka I. An Outline of the Phonetic Typology of the Slavic Languages. Toruń: Wydawnictwo Uniwersytetu M. Kopernika, 2001.

34. Sebba M., Mahootian Sh., Jonsson C. Language Mixing and CodeSwitching 67 in Writing; Approaches to Mixed-Language Written Discourse. Routledge, UK, 2012. P. 22-29.

35. Thomas E. Sociophonetics. An Introduction. Basingstoke. New York : Palgrave Macmillan, 2011. 272 p.

36. Toivanen J. Tone of Choice in the English Intonation of Proficient Non-native Speakers. Phonum. 2003. Vol. 9. P. 165-168.

37. Valian V. Bilingualism and Cognition. Bilingualism. Language and Cognition. 2015. Vol. 18(1). P. 3-24.

38. Vogt H. Language contact. Word. 1954. Vol. 10(2-3). P. 365-374.

39. Weinreich U. Languages in Contact. The Hague: Mouton, 1968. 411 p.

Information about the author:

Devitska A. I.,

Candidate of Philological Sciences, Associate Professor at the Department of Theory and Practice of Translation, Uzhhorod National University 45, Universytetska str., Uzhhorod, 88000, Ukraine 


\section{STRUCTURAL APPROACH TO THE STUDY OF MEANING (ON THE MATERIAL OF ADJECTIVES IN MODERN UKRAINIAN)}

\section{Fabian M. P.}

\section{INTRODUCTION}

In recent years, the problem of meaning has been explored in all its manifold aspects. Philosophers, philologists, psychologists, anthropologists, students of literature and arts, even economists and scientists working in different spheres of human activities have joined in the debate. Meaning seems at once the most common feature of language and the most obscure aspect to study. It is obvious because it is what we use language for - to communicate with each other, share knowledge, experience, give information, advice, warn about something, etc. as well as to convey what we mean effectively. But the steps in understanding what has been said to us in a language we speak are so rapid, so transparent, that we are little conscious of both principles and knowledge which underlie this communicative ability.

Two major branches of linguistics are specially concerned with words: etymology, the study of word origins, and semantics, the study of word meanings. Of the two, the former is an old-established discipline whereas the latter is comparatively new. The need for an independent science of meaning was not felt until the XIXth century when it emerged as an important part of linguistics and received its modern name. Two main factors played a decisive part in the emergence of semantics: the rise of comparative philology, more generally, the scientific linguistics in its modern sense, and the influence of the Romantic Movement in literature. The Romantics had an intense interest in words, and they were fascinated by the strange as well as mysterious potencies of different words. According to the history of semantics, it covers three distinct periods: the first which lasted approximately half a century, was described as the "underground period" of semantics when German scholars welcomed Reisig's initiative to pay attention to meaning rather than form as the latter prevailed in philological studies of that time. The second period in the history of semantics began in the early 1880s and lasted for almost half a century. This time it was due to Bréal who outlined the programme of the new science and named it the way it is used at present. The abovementioned philologists regarded semantics as a purely historical 
study, and so most semanticists considered that their prime task was to study changes of meaning, their causes, to classify them according to various (psychological, logical, etc.) criteria, and, if possible, to formulate both general laws and tendencies underlying them. Since the turn of the century, certain fundamental changes took place in General linguistics: F.de Saussure's innovative approach to the study of language which treated the latter as an organized totality comprised of various interdependent elements which, in their turn, derive their significance from the system as a whole. He compared language to a game of chess where no unit can be added, removed or displaced without altering the entire system of relations on the chessboard. This vision of language as a system of interdependent elements lies at the root of what is called structural linguistics nowadays. Trier's work on terms of knowledge in German was the first serious attempt to introduce F.de Saussure's principles into semantics. The new semantics differed much from the traditional approach: it focused on the study of the inner structure of the vocabulary, shifted from general principles to the study of particular languages.

Contemporary semantics is a self-contained and integral department of philology. It makes use of achievements obtained from related as well as non-related branches of sciences. Together with traditional applications of the study of meaning, the present research introduces structuralist conception of meaning which makes possible to use the structural approach to the study of adjectives in modern Ukrainian.

\section{Lexical semantics of adjectives in modern Ukrainian}

Semantics, the theory of meaning, is the youngest branch of modern linguistics. Three sets of problems confront the semanticist at the very outset of his work: the terminology and the very name of his science; its relation to some extra-linguistic pursuits of the same name; finally, the place to which it is entitled in the general structure of modern linguistics ${ }^{1}$. Structural semantics is mainly concerned with word semantics, and it is not confined to isolated language units, but focuses on lexical fields and paradigmatic semantic relations between them. Lexical semantics, especially the ways of its study, belongs to less investigated issues of modern linguistics, which are open to thought and discussion, and need their further in - depth study. Attempts have been made to describe and analyze different lexical structures into which the words are organized. These inquiries are conducted at the levels of single words, conceptual spheres and vocabulary as a whole. Our approach to the

${ }^{1}$ Ullmann S. The Principles of Semantics. Glasgow: Jackson \& Co, Oxford: Basil Blackwell, 1957. P. 4. 
study of lexical semantics is an attempt to combine the first two levels, on the basis of which the entire vocabulary of a language can be studied. There are many different approaches to the way in which meaning in language is studied, but what we shall be concerned with is the semantic classification of lexis, and it is the author's attempt to shed light on lexical semantics' study, combining pure linguistic with mathematical methods. Put together, they make up the formalized basis for the semantic classification of lexis, with the help of which nearly all groups of lexis can be studied. Significantly, these groups can be revealed and thoroughly analyzed not only within one language system, but also in comparison with other both related and non - related ones.

The central idea of our structural approach to the study of meaning is that language has to be treated as a system of interrelated and hierarchically organized elements which, in their turn, also form a definite system. As Geeraerts D. puts it, if you focus the study of linguistic meaning on individual items, then you will automatically be interested in the different meanings items may have, and in the relations that exist among those meanings $^{2}$. The Ukrainian language as a system of signs, has its own properties and principles which determine the functioning of these signs. The latter are the part of the language system, and we describe them within it, and also in their relationships to other signs in the system under study. Moreover, the vocabulary of the language is a network of expressions that are mutually related by all kinds of semantic links. If we consider language as a system of signs, or, following F.de Saussure, as a structure of interdependent elements, then we can distinguish at least two types of structure in the lexicon, namely external (to the word) and internal (to the meaning). The term "lexicon" is used by Lipka L. in two senses that are not always sharply distinguished: a) for a metalinguistic level, or a subcomponent in a linguistic model (basically compatible with a variety of theories of language); and b) in the sense of vocabulary as seen from a systematic, synchronic point of view ${ }^{3}$.

Adjectives make up the class of inflected words. They show the extent or degree to which the quality they express applies to the word they modify, especially in relation to other things or conditions of the same kind. Our research deals with structural approach to the study of lexical semantics of adjectives denoting the property of being respected. All the lexical units in question make up a definite system which consists of elements (adjectives themselves) that are hierarchically placed within this system. Moreover, they are closely interrelated and interconnected, and the same concerns their meanings. Semantics of adjectives is studied with the

\footnotetext{
${ }^{2}$ Geeraerts D. Theories of Lexical Semantics. Oxford: Oxford University Press, 2010.P.50.

${ }^{3}$ Lipka L. English Lexicology: Lexical Structure, Word Semantics and Word-formation. Tübingen: Narr, 2002. P. 13.
} 
help of componential analysis which remains one of the most efficient means of the lexical meaning study. Much attention is paid to the way lexical meanings of the adjectives denoting the properties of being respected in Ukrainian are structured with the help of componential analysis as well as mathematical and statistical methods.

Great achievements of both mathematical and structural linguistics made it possible to create a formalized basis for the semantic classification of lexis, according to which language is treated as a system of a certain structure where each lexical unit occupies its definite place, and stands in certain relationships to other lexical units. Having introduced formal, purely linguistic criterion- belonging of the words to a definite part of speech - the adjective, an in-depth study of their semantics is carried out on the basis of the continuous analysis of the Ukrainian explanatory dictionary ${ }^{4}$. Methodology of collecting, classifying and analyzing our language material lies in the following successive steps:

- from the biggest Ukrainian explanatory dictionary, the adjectives, the lexical meanings of which contain the properties of being respected, esteemed, honoured, etc. are selected;

- on the basis of the obtained lists of words, the card indices are piled;

- both common and distinctive qualitative and quantitative analyses of the words under study as well as their semantics are made.

The adjectives under study denote classes of qualities bound together by some common element (the property of being respected). We agree with Ullmann S. that the words are never completely homogeneous: even the simplest and the most monolithic have a number of different facets depending on the context and situation in which they are used, and also on the personality of the speaker using them ${ }^{5}$.

37 adjectives are widely used in Ukrainian to describe qualities of people deserving respect due to their certain merits and everyday life activities. Here belong the lexical units поважний, сприятливий, обачний, ввічливий (увічливий), маститий, дорогочінний, вельмишановний, величавий, статечний, вашецький (вамеський), поважаний, святий, останній, посмертний, тречний, побожний, земний, уклінний, почесний, чесний, шанобливий, величний, високошановний, поштивий (почтивий), превелебний, славетний, чемний, преславний, величальний, священний, шановний, гідний, високоповажаний, високоповажний, благоговійний, святобливий, добрий.

${ }^{4}$ Словник української мови: В 11-ти т. Київ: Наукова думка,1970-1980.

${ }^{5}$ Ullmann S. Semantics. An Introduction to the Science of Meaning. Oxford: The Alden Press Basil Blackwell,1962. P. 124. 
Each of these adjectives possesses the following semantic characteristics: поважний - 1. Який заслуговує, вартий поваги; який користується повагою.// Відомий своєю роботою, заслугами, посадою. // Немолодий. // Уживається при звертанні. 2. Який відзначається вдумливістю, серйозністю. // Сповнений поваги, серйозності; який виражає повагу, серйозність, вдумливість. 3. Сповнений гідності; величний. // Урочистий. 4. Авторитетний, значний. 5. Серйозний за своїм змістом, характером, темою. 6. Який має неабияке значення. Важливий, значний.// Який заслуговує особливої уваги внаслідок своєї важливості, значимості.// Який може бути прийнятий до уваги; достатній для виправдання чогонебудь. 7. Повільний, не швидкий.// Протяжний, задумливий (про пісню, мелодію). 8. Діал. Великий (розміром, кількістю). У поважному стані - вагітна. The word сприятливий means який позитивно впливає на що-небудь, створює відповідні умови для здійснення, виконання і т. ін. чогось. // Потрібний, необхідний для чого-небудь; належний. // Зручний для чого-небудь. // У якому виражається прихильність, шанобливе ставлення, повага до кого-небудь. The adjective обачний expresses 1. Який діє розумно, спокійно, непередбачливо.// Який виявляє обережність у своїх діях, не наражається на неприємність, небезпеку; обережний. 2. Який зважає на інтереси, запити інших, виявляє повагу до них; чемний, уважний.

The next lexical units meriting our attention are ввічливий (увічливий) and маститий. The first means який дотримується правил пристойності, виявляє уважність, люб'язність; чемний. // В якому проявляється уважність, люб'язність, and the latter - який заслужив загальну повагу, визнання своєю багаторічною плідною діяльністю (про діячів науки, мистецтва тощо).

Among the synonyms belonging to the group of adjectives under study one can mention the following ones: вельмишановний - Гідний великої поваги (узвичаєна форма ввічливості при звертанні до когось або при згадуванні когось); величавий - 1. Який своїми розмірами, виглядом або діями, вчинками викликає почуття поваги, певної урочистості. // сповнений урочистості. 2. Який тримається 3 великою гідністю, гордовитістю; вашещький (вашеський) - Гідний поваги; шановний. // ірон. Гордовитий, пихатий; поважаний - 1. Дієпр. акт.теп. ч. до поважати 1. 2. Якого поважають, який користується повагою в когонебудь.// Уживається як формула ввічливості при звертанні; благоговійний - Сповнений найщирішої поваги, шани; безмежно відданий; побожний; гідний - 1. Який заслуговує або вартий чогонебудь. 2. Який відповідає вимогам часу, обставинам; належний.// Цілком відповідний у даному випадку; потрібний. 3. Такий, що має 
високі позитивні якості; достойний. 4. діал. Шановний; величальний Який вшановує, звеличує кого-небудь; шановний - Якого поважають, шанують. // Уживається як складова частина ввічливого звертання. // Уживається для вираження фамільярної оцінки кого-, чого- небудь. Той, кого поважають, шанують (перев. у звертанні); чемний Шанобливо ввічливий до людей. // В якому виявляється ввічливість, уважність, люб'язність; славетний -1. Який має широку славу, популярність; знаменитий.// Добре відомий багатьом, усім. // Прославлений героїчними ділами, подвигами і т. ін. // Пов'язаний 3 героїчними ділами, подвигами. // Який прославляє кого-небудь. 2. Гідний поваги, пошани; преславний - 1. Який надзвичайно уславив себе чим-небудь, достойний великої слави. // Відомий дуже широким колам людей; славнозвісний. // Який приносить, приніс комусь велику славу. 2. Який викликає велику симпатію; дуже гарний, приємний. Який викликає велику симпатію; дуже гарний, приємний.// Який відзначається, вирізняється чимсь особливим. 3. Вельмишановний (при шанобливому звертанні до кого-небудь).// у знач. Преславний, преславні. Уживається у звертанні до високоповажних осіб; поштивий (почтивий) - 1. Який виявляє повагу до кого-небудь; чемний, ввічливий. 2. Гідний пошани, поваги; високошановний - Гідний великої пошани, поваги (вживається при офіційно-ввічливому звертанні до кого-небудь або в розмові про когось); шанобливий - Сповнений глибокої поваги, пошани до кого-, чого-небудь. // Який виявляє глибоку повагу, пошану до кого-небудь. // Сповнений виразу глибокої поваги, пошани до кого-, чого-небудь; уклінний - Який виражає пошану; шанобливий. // Який виражає покору, смиренність; тречний Шанобливо ввічливий у поводженні з людьми; чемний. // Який виражає шанобливість, увічливість.

While making lexico-semantic analysis of our language material, we have come across the words which are absolute synonyms and fully coincide in their meanings: високоповажаний - Те саме, що високошановний and високоповажний - Те саме, що високошановний. It means that due to this semantic specificity they acquire the meaning of the adjective високошановний - Гідний великої пошани, поваги (вживається при офіційноввічливому звертанні до кого-небудь або в розмові про когось). То bе respected, one should have high standards and good personal qualities such as fairness, honesty, responsibility for other people as well as for their deeds, etc. Such a variety of semantic connotations is revealed by the inner structures of the adjectives чесний, почесний and статечний. The first in this line is the lexical unit чесний - 1. Який відзначається високими моральними якостями. // не здатний украсти що-небудь, не схильний до крадіжки. // 
Який виражає правдивість, прямоту характеру, відвертість (про обличчя, погляд і т. ін.). // Властивий людині, яка має високі моральні якості. // Який старанно, ретельно виконує свої обов'язки; сумлінний. // Той (та), що має високі моральні якості, правдивий, відвертий. 2. Сумісний 3 поняттям честі, чесності, 3 правилами честі. // Який випливає з сумлінного ставлення до своїх обов'язків. // Зароблений без обману, своєю сумлінною працею. 3. Який не заслуговує ніякої догани; порядний, нічим не заплямований. // Яка зберігає свою жіночу честь, дівочу невинність, цнотливість. 4. Шановний, поважний, сповнений честі (у 2 знач.). // Який заслуговує на високу повагу, пошану. 5. Шановний за святістю і релігійністю.// При звертанні до духовної особи. The second in the line is the word почесний - 1. Гідний поваги, пошани. // Який користується повагою, пошаною. 2. Призначений для вияву поваги, пошани. // Такий, що надається на знак поваги, пошани. // Такий, що обирається на знак поваги, пошани. 3. Який робить честь кому-небудь. // Честь або гідність якого не принижено. The third to focus on is the adjective статечний - 1. Розсудливо-серйозний, розважливий у вчинках; з позитивними якостями (про людину); поважний. // Властивий розсудливо-серйозній, поважній людині, характерний для такої людини; сповнений гідності, поважності. 2. Який справляє враження, привертає увагу своєю зовнішністю; показний. 3. Який має достаток; заможний. 4. Немолодий, середнього віку; літній. 5. Який справляє позитивне враження, відзначається порядністю; пристойний, добропорядний. 6. Який заслуговує поваги своїм значенням, достоїнством і т.п.

There are adjectives in our language material semantics of which is closely connected with the characteristics of people's qualities directed towards religious worship, reverence, God, devotion, religious rituals, ceremony, church, religion, cross, belief, piety and the like. To such lexical units belong: святобливий - 1. Який вірить у бога й старанно виконує всі релігійні обряди; побожний. // Який виражає побожність. 2. Сповнений найщирішої поваги, шани; священний - 1. Пов'язаний з релігією, церквою. // Який має божественну силу. // Який є предметом релігійного поклоніння. 2. Який ведуть, здійснюють в інтересах релігії. 3. Який глибоко шанують; дорогий, заповітний. // Те, що глибоко шанують. // Якого мають дотримуватися всі, обов'язковий для всіх. 4. На який не можна посягати. 5. Високий, благородний. // Особливо почесний. // Метою якого є воля, визволення, мир і т. ін. (про боротьбу, війну тощо); святий - 1. Пов'язаний з релігією, богом, наділений божественною силою. // Перейнятий божественною силою. // Уживається як постійний епітет до слів, пов'язаних із місцями або предметами релігійного поклоніння. // Освячений. // Уживається при вираженні переляку, подиву, обурення. 
2. Який, за християнською релігією, провів життя в служінні богові й якого після смерті церква визнала небесним заступником віруючих. // Праведний, непорочний, угодний богові. // Люди, які все життя присвятили служінню богові й після смерті визнані церквою небесними заступниками віруючих. // Те саме, що ікони. 3. Уживається як постійний епітет до свят, визначених релігією. 4. Морально чистий, благородний, бездоганний у житті, поведінці тощо. // Не винний у чомунебудь, перед кимсь; безгрішний. // Людина, яка не винна ні в чому, ні перед ким. // Чистий, благородний. // Який виражає чистоту, благородство (про очі, обличчя і т. ін.). // Освячений високою метою. // Особливо почесний. 5. Який глибоко шанують; дорогий, заповітний. // Те, що глибоко шанують.// Непорушний, непохитний.//кого мають дотримуватися всі, обов'язковий для всіх. // Звичний, природний, особливо бажаний.

Some adjectives under study have a big communicative potential, and they are frequently used in both verbal and non-verbal communication. The latter is closely connected with a man of worship, the figure of bishop, various forms of addressing people, expressions of cult, religion, churchservice, homage, a particular system of religious worship, commemoration, etc. Here belong the adjectives превелебний - 1. Титул єпископа. 2. Гідний великої поваги, пошани (часто при ввічливо-шанобливому звертанні до когось). // Пов'язаний з вираженням великої поваги, пошани до кого-небудь; побожний - 1. Який ревно виконує всі релігійні обряди; віруючий. // Властивий релігійній, віруючій людині. 2. Пов'язаний з релігією; церковний. 3. Сповнений найщирішої шани, безмежно відданий; благоговійний, шанобливий; посмертний 1. Який буває, відбувається після чиєїсь смерті (перев. для вшанування його пам'яті). // Який був опублікований або став відомим після смерті автора (про літературний твір, лист і т. ін.). // Який приходить до кого-небудь або надається комусь після смерті (про славу, визнання, звання і т. ін.). 2. Те саме, що загробний.

As it is seen from the meanings of the words in question, these adjectives are characterized by their ability to be used in different contexts as well as in various situations. In this respect of great value are those meanings which describe not only religious notions but also the matters of everyday importance (a literary piece of writing or letter being recognized after its author's death, glory and title given to somebody after his/her death as a recognition of his/her merits, achievements, etc., something done or performed in memory of and the like).

Certain situational meanings can be found in the semantics of the adjectives used in collocations земний уклін - уклін до землі як вияв 
особливої шани кому-, чому-небудь (a low bow, obeisance as an expression of special respect, regard somebody or something is treated with) and віддавати (віддати) останню шану (послугу і т. ін.); посилати останній привіт кому; проводжати в останню путь - виражати пошану до померлого, прощаючись з ним (doing homage to somebody, showing the last respects to the dead, parting, farewell words to the deceased). The adjective дорогоцінний is used in verbal communication as a form of address to express one's regards, friendliness, goodwill. Being admired, respected and excited also lead to one's appreciation of somebody or something which describe people's qualities expected in the society. For example, the lexical unit величний has three meanings, each of which characterizes the property of being admired, esteemed, worthy of respect, filled with surprise, the feeling of solemnity, something important, extraordinary, etc.: 1. Який своєю величиною, грандіозністю, силою прояву або наявністю чогось видатного, надзвичайного викликає подив, захоплення. // Який викликає почуття урочистості, піднесеності. 2. Сповнений гідності, поважності. 3. Який заслуговує пошани, поваги.

Such qualities of people as being held in respect, treated with honour, deserving recognition are closely related to the positive human traits of character, ability to reveal friendly, tactful, sincere, sympathetic, kind attitudes to others, establish kind, cordial relationships, properties of being full of joy, openness, kindness, sincerity (about voice, smile face, etc.), wellbred, hard-working, polite as well as good qualities of something which answer the required standards, volume or quantity concerning animals, plants, objects, well and vividly represented, sharp (concerning the appetite, sight, hearing, etc.). All the abovementioned meanings characterize the adjective of broad semantics добрий. It possesses 9 rather extended meanings which can be interpreted the following way: 1. Який доброзичливо, приязно, чуйно ставиться до людей; доброзичливий; протилежне лихий, поганий. // Привітний, лагідний у взаєминах. // Той, хто доброзичливо, приязно, чуйно ставиться до людей. // Який виражає доброту, щирість; сповнений ласки, приязні (про голос, усмішку, обличчя і т. ін.). 2. Для якого характерна взаємна прихильність, симпатія; близький. 3. Який приносить добро, задоволення, радість. // Корисний, потрібний, в основі якого лежить бажання добра комунебудь. // В якому виражається прихильність, співчуття, доброзичливе, шанобливе ставлення, повага до людей. // Який подобається, схвалюється; вартий наслідування. // Який свідчить про безтурботний, веселий стан людини. 4. Який має належні знання i навики для виконання чого-небудь; досвідчений. // Який користується повагою, шаною. // Розумно вихований, увічливий, працьовитий. 5. Який має 
позитивні якості або властивості, що відповідають поставленим вимогам, задовольняють їх (про предмети, тварини, рослини). // Вигідний, зручний для роботи, влаштування яких-небудь справ, заробітку. 6. Значний щодо розміру, обсягу, кількості. // Кращий від звичайного, багатий, великий, високий. // Помітно виражений, гострий (про апетит, зір, слух). // Дуже розвинений. // Значний щодо ступеня вияву, сили. 7. Гідний шани, похвали; незаплямований. 8. Те саме, що смачний. 9. Уживається для підкреслення важливості, значності кількісного визначення міри часу, простору.

Lexical semantic analysis of adjectives denoting the property of being respected in modern Ukrainian revealed their both common and distinctive features as well as peculiarities of their system and structural organization.

\section{Seme structure of adjectives in modern Ukrainian}

The study of how meaning is encoded in a language is the subject matter of semantics. It is generally assumed that its main concern is the meanings of words as lexical items. But we have to note that it is not only concerned with words as such. What is meaning? Philosophers have debated the question, with particular reference to language, for over 2000 years. No one has yet produced a satisfactory answer to it. One reason for this may be that the question, in the form in which it is posed, is unanswerable. It makes two presuppositions which are, to say the least, problematical: (a) that what we refer to, in English, with the word "meaning" has some kind of existence or reality: (b) that everything referred to as meaning is similar, if not identical, in nature. We may call these, respectively: (a) the presupposition of existence and (b) the presupposition of homogeneity. ${ }^{6}$ According to the most widely accepted theory of semantics, by meanings we mean ideas or concepts, which can be transferred from the mind of the speaker to the mind of a hearer by embodying them in the forms of one language or another. In linguistics meaning is what a language expresses about the world we live in or any possible or imaginary world ${ }^{7}$.

There are many different approaches to the way in which meaning in language is studied. Philosophers have investigated the relations between linguistic expressions, such as the words of a language and persons, things and events in the world to which these words refer. Linguists have

${ }^{6}$ Lyons J. Language and Linguistics. An Introduction. Cambridge: Cambridge University Press, 1981. P. 136.

${ }^{7}$ Longman Dictionary of Language Teaching \&Applied Linguistics. Longman Group UK Limited, 1992. P. 222. 
studied the way in which meaning in a language is structured and have distinguished between different types of meanings. The complexity of word meaning is manifold. Various attempts have been made to work out efficient procedures for the analysis and interpretation of meaning. Our lexico-semantic analysis of adjectives in modern Ukrainian presupposes the all-round study of their meanings. The latter, like the lexical units themselves, are treated as a system which is composed of hierarchically placed semes. To describe and characterize them, componential analysis is used. It is one of the contemporary methods of semantic research which is applied to the study of meaning and analyses a word into a set of meaning components or semantic features. Componential analysis provides an inventory of the semantic features encoded in lexical forms. The essential purpose of it is to identify certain general conceptual categories or semantic principles which find expression in the particular components ${ }^{8}$.

The meanings of words may be described as a combination of semantic features. The latter are classified into semantic markers by which we mean the semantic features present in the lexical meanings of other words and distinguishers - semantic features which cannot be found in the lexical meanings of other words. Furthermore, semantic markers refer to features which the word has in common with other words, whereas distinguishers refer to what differentiates or distinguishes a word from other ones. In European semantic theory the meanings are reduced to minimal components or semes, as they are called. Componential analysis proceeds from the assumption that word meaning is not an unanalyzable whole but can be decomposed into elementary semantic components, or semes. It is also assumed that these basic semantic elements can be classified into several subtypes thus ultimately constitute a highly structured system ${ }^{9}$. Different scholars suggest different terms to name this elementary constituent of meaning: semantic component, semantic features, figures of content, differential semantic elements, semantic primitive, semantic multiplier, semantic function, semantic parameter, etc. There are also such types of semes as: classeme, archeseme, differential semes, integrative semes. A distinction is also made between denotative and connotative ones. The former belong to the denotative component of meaning whereas the latter are the additional semantic components representing the connotative component of meaning. There exists the classification of semes into contextual, implicit and explicit. The structural approach to the study of semantics presupposes the use of componential analysis which bears

\footnotetext{
${ }^{8}$ Widdowson H.G. Linguistics. Oxford: Oxford University Press, 1996. P. 57.

${ }^{9}$ Sukhorolska S.M., Fedorenko O.I. Methods of Linguistic Analysis. Lviv: Publishing Centre of Ivan Franko Lviv National University, 2006. P. 116.
} 
resemblance to the mathematical process of factorizing a number, and a useful informal method of arriving at components of meaning is suggested by the analogy of arithmetical proportions ${ }^{10}$.

Componential analysis in our research is carried out on the basis of dictionary definitions (definitional analysis). In this respect the explanatory dictionary of the Ukrainian language plays a significant role in the studies of such types. It makes up an empirical basis of modern semantics as it presents the whole lexical system of the language in question. Of primary importance here are definitions of words which reveal various relations between words, when one is explained by means of the other together with their profound characteristics. Lexical meaning of the word is treated as an independent entity possessing its individual linguistic quality. The structure of each dictionary entry is conditioned by both volume and quantitative specificity of an individual lexical meaning. As a result, in dictionary definitions the lexical meanings are divided into rubrics and subrubrics.

Explanatory dictionary of the Ukrainian language is at the same time the object of linguistic study and the means of carrying out both theoretical and applied research works. It is treated as the complete fullest bank of information concerning the language under study which had been compiled taking into account the whole verbal and written products. Our research of adjectives denoting the property of being respected in modern Ukrainian is carried out on the basis of dictionary definitions by means of applying the structural approach to the study of the adjectives' lexical semantics. The procedure of dividing the lexical meanings of adjectives into semes presupposes their strict and thorough analysis. Even punctuation marks in dictionary definitions matter: comma means that the semes stand close in meaning; semi-colon denotes separation of the meaning components. Moreover, one and the same seme may form the meanings of more than one word. This quantitative characteristics of the semes forms one of the regularities of their system and structural organization. This gives grounds to consider to what extent the meanings of adjectives are related to each other.

Seme data set contains 175 definitions, among which one can find indications of positive human qualities, namely being respected, loyal, kind, sincere, well-bred, polite, recognized by other people due to his/her heroic deeds, high moral standards, everyday activities, social life, position in the society, charity, achievements in various branches of science, the feeling of responsibility, friendly attitude to all members of the society, etc.

\footnotetext{
${ }^{10}$ Fabian M. Lexical Semantics: New Approach to its Study // Journal of Interdisciplinary
} Philology 2013. № 1-2. P. 5-12. 
The whole seme data set is divided into 5 subsets: 1) positive properties of human character; 2) qualities of person's attitude towards other people; 3) the properties of being honoured, esteemed, recognized; 4) who enjoys popularity, glory, recognition due to his/her good name, authority, good reputation, renown, which (who) positively influences something, creates proper conditions for fulfilling the tasks, necessary, good for something; who acts wisely, quietly, carefully, with great caution, takes into account the interests of others; 5) contextual semes.

Semantic markers який виявляє глибоку повагу, пошану до кого-, чогонебудь, сповнений виразу глибокої поваги, який виражає пошану, гідний великої поваги, який має позитивні якості або властивості, що відповідають поставленим вимогам characterize the semantic meanings of nearly all the adjectives under study. The first subset contains the semes сповнений найщирімої поваги, шани; безмежно відданий; побожний which can be found in the semantics of the adjective благоговійний, шанобливий, добрий, святобливий; шанобливо ввічливий до людей; в якому виявляється ввічливість, уважність, люб'язність (чемний); який виявляє глибоку повагу, пошану (шанобливий); який виражає покору, смиренність (уклінний); який відзначається високими моральними якостяли, не здатний украсти, не схильний до крадіжки, який виражає правдивість, прямоту характеру, відвертість, який старанно, ретельно виконує свої обов'язки, сумлінний, який випливає з сумлінного ставлення до свойх обов'язків, зароблений без обману, своєю сумлінною прачею, який не заслуговує ніякої догани, порядний, нічим не заплямований, шановний, поважний, сповнений честі (чесний), якого поважсають, який користується повагою в кого-небудь (поважаний), який має позитивні якості або властивості, щзо відповідають поставленим вимогам, задовольняють ӥх, який приносить добро, задоволення, радість, який подобається, схвалюється, вартий наслідування, розумно вихований, увічливий, працьовитий, гідний шани (добрий), сповнений найщирімої шани, безмежно відданий, благоговійний, шанобливий (побожний), розсудливо-серйозний, розважсливий у вчинках, з позитивними якостями, поважний, сповнений гідності, поважності, який справляє позитивне враження, відзначається порядністю, пристойний, добропорядний (статечний), який має широку славу, популярність, знаменитий, добре відомий багатьом (славетний), такий, щэо має високі позитивні якості, достойний (гідний).

The second subset covers the semes which analyze the multiple ways of expressing qualities of person's attitude towards other people: який доброзичливо, приязно, чуйно ставиться до людей, доброзичливий, привітний, лагідний у взаєминах, той, хто приязно, чуйно ставиться 46 
до людей, який виражає доброту, щиирість, сповнений ласки, приязні, для якого характерна взаємна прихильність, симпатія, близький, корисний, потрібний, в основі якого лежить бажання добра кому-, чому-небудь (добрий); який діє розумно, спокійно, передбачливо, який зважає на інтереси, запити інших, виявляє повагу до них, чемний, уважний, який виявляє обережність у своӥх діях, не наражається на неприємність, небезпеку, обережний (обачний), який прославляє кого-небудь (славетний), який виявляє повагу до кого-небудь, чемний, ввічливий (поштивий, почтивий), шанобливо ввічливий у поводженні з людьми, який виражає шанобливість, увічливість (гречний). As it is seen from the research, several semes enter more than one or two subsets, and this shows close relationships between them in the system.

The third subset contains the semes revealing the properties of somebody or something who (that) deserve respect, regard, trust, authority, attention, heed, consideration, is influential, answer the demands of time, circumstances, arise surprise, admiration, wonder, the feeling of solemnity, excitement, do not tolerate objection, etc. який заслуговує помани, поваги, сповнений гідності, поважності, який своєю величиною, грандіозністю, силою прояву або наявністю чогось видатного, надзвичайного викликає подив, захоплення (величний), який користується авторитетом, впливовий, який заслуговує на повне довір'я, який не терпить, не допускає заперечень (авторитетний). пов'язаний з вираженням великої поваги, пошани до кого-небудь, гідний великої поваги (превелебний). This adjective is frequently used as a polite and respectful form of addressing somebody and as a title of bishop. To the subset under study also belong the following semes: який заслуговує поваги свойм значенням, достойнством (статечний), гідний поваги, пошани, який обирається, надається на знак поваги, пошани (почесний), якого поважають, шанують, той, кого поважають, шанують (шановний), гідний великої пошани, поваги (поштивий, почтивий, високошановний, славетний).

The words високошановний, високоповажаний, високоповажний are used as an official polite form of address or when speaking about somebody. Its synonym вельмишановний is a polite form of addressing or recollecting somebody. The meanings of lexical units вашецький, вашеський contain stylistically marked semes, on the one hand, гідний поваги, шановний and ірон. гордовитий, пихатий (ironically - haughty, disdainful), on the other. The semes який свойми діями, вчинками і т.ін. викликає почуття поваги, певної урочистості, який тримається з великою гідністю, гордовитістю characterize lexical meanings of the word величавий. Those who due to their long-lived fruitful activity deserve general acknowledgment and recognition are called маститий 
(venerable). Among distinguishers in our language material one can mention який відповідає вимогам часу, ичілком відповідний у даному випадку, потрібний (гідний), немолодий, повільний, не швидкий, протяжний, задумливий (про пісню, мелодію), великий (розміром, кількістю), який може бути прийнятий до уваги, достатній для виправдання чого-небудь, який заслуговує особливої уваги внаслідок своєї важливості, значимості (поважний), який дотримується правил пристойності (ввічливий, увічливий), зручний для чого-небудь (сприятливий), побожний (благоговійний), вигідний, зручний для роботи, влаштування яких-небудь справ, заробітку, значний щодо розміру обсягу, кількості $i$ m. ін., кращий від звичайного, багатий, великий, високий, який повністю забезпечує потребу в чому-небудь, дуже розвинений, значний щуодо ступеня вияву, сили, уживається для підкреслення важливості, значності кількісного визначення міри часу, простору (добрий), який має достаток, заможний (статечний), який вірить у бога й старанно виконує всі релігійні обряди (святобливий), шановний за святістю і релігійністю (чесний).

The fourth subset covers those semes which describe deeds, actions, activities, happenings and the like leading to something special, of good quality, positive necessary changes, respect, recognition, devotion, connected with God, religion, church, religious rituals, love, faithfulness, stability, freedom, peace, glory, nobility, popularity, big money, values, something very important, the sense of dignity, place in the society, power, business dealings and real life situations. Here belong the semes який позитивно впливає на що-небудь, створює відповідні умови для здійснення, виконання чогось (сприятливий), який приносить, приніс комусь велику славу, відомий дуже широким колам людей, який відзначається, вирізняється чимсь особливим (преславний), який ведуть, здійснюють в інтересах релігї, високий, благородний, метою якого є воля, визволення, мир, властивий релігійній, віруючій людині (побожний), який вшановує, звеличує кого-небудь (величальний), який коштує великі гроші, дуже иінний, дорогий, дуже важливий (дорогоцінний), життєвий, реальний (земний), гордий, з виразно виявленим почуттям власної гідності, який має добру якість, пов'язаний із значним службовим становищем, владою (важний), який присвятив себе чому-небудь, який, будучи пройнятий симпатією, любов'ю до когось, чогось, відзначається постійністю, вірністю (відданий). Some of the semes mentioned in the subsets are common for the lexical meanings of a rather great majority of words under study. Even their division into subsets is conventional because the semes, like lexical units, in our research are represented as open systems which can be enlarged if further studied. 
The fifth subset is made up by contextual semes which characterize the lexical meanings of the adjectives посмертний (post mortem): загробний, святий (saint): як постійний епітет до слів, пов'язаних із місиями або предметами релігійного поклоніння, освячений, уживається при вираженні переляку, подиву, обурення, праведний, непорочний, угодний богові, стосовно до великодня, почесний (honourable): честь або гідність якого не принижено, побожний (pious): який ревно виконує всі релігійні обряди, віруючий, and священний (sacred): який є предметом релігійного поклоніння, який ведуть, здійснюють в інтересах релігії, на який не можна посягати, високий, благородний, особливо почесний. All the abovementioned semes can be used in the contexts which specify the semantics of the adjectives in question. Seme in our research identifies a minimal feature of meaning, i.e. a minimal feature of the semantic structure of an adjective. Componential analysis in the present research is formalized as far as the symbolic representation of meaning components is concerned. Being applied to the study of adjectives as a definite system of the vocabulary, the componential analysis helped disclose the system and structural organization of the words in question as well as reveal their lexical and seme stock together with all their common and distinctive features.

\section{CONCLUSIONS}

Lexical semantics, especially the methods and procedures of its analysis, belongs to less investigated problems of modern linguistics. It is that system of language which is never stable, and, due to both lingual and extra - lingual factors, undergoes changes of different types. It is most sensitive to scientific and technological progress, our everyday life and activities, global world changes, etc. Despite great achievements in various branches of linguistics, still there are certain areas which are by no means complete. In the first place it concerns the structural approach to the study of lexical meaning. In the paper this problem is considered on the example of adjectives denoting the property of being respected in modern Ukrainian. The suggested approach in the present research makes up the formalized basis for the semantic classification of a certain fragment of lexis, according to which the Ukrainian language is treated as a system of definite structure, where each lexical unit occupies its definite place, and establishes various types of relationships with other ones within this system. Not only adjectives themselves are looked upon this way, but also both their meanings and semantic components. Our language material has been collected, analyzed and classified on the basis of a continuous study of the most authoritative Ukrainian explanatory dictionary. To choose 
the material of the research, we have introduced formal, purely language criterion - belonging of the lexical units to a particular part of speech the adjective. As a result, the property of being respected embraces 37 adjectives possessing 175 meanings. Taken together, they form an open-ended system of elements which are interrelated and interdependent. Nearly all the words under study are polysemantic, and their semantics is broad: from revealing the qualitative characteristics of people, their deeds, ways of life, behaviour and distinguishing features of character to describing the properties of being honoured, respected, recognized and acknowledged because of their spiritual and moral qualities. The meanings of the adjectives in question have been studied with the help of componential analysis which is considered to be of great value in contemporary linguistics. They are composed of components which, in their turn, also make up a definite system, and these components (semes) are both interrelated and interconnected. As seen from the study, they form subsets, they enter the meanings of more than one, two, etc. lexical units, undergo classifications, specify the shades of words' meanings and add additional information concerning the words' usages. By penetrating deep into the adjectives' semantics and peculiarities of their inner system and structural organization in Ukrainian, it is possible to contribute to the further study of meaning, and open new possibilities of discussing other issues of semantics which remain unsolved.

\section{SUMMARY}

The present research deals with the structural approach to the study of meaning on the material of adjectives denoting the property of being respected in modern Ukrainian. The language material is collected, analyzed and classified with the help of a continuous analysis of the Ukrainian explanatory dictionary. Both the words and their meanings are divided into groups (subsets) which contain the whole semantic characteristics of the adjectives themselves and their corresponding meaning components (semes). Each of these groups is treated as a definite system consisting of hierarchically placed elements, which occupy their definite places within the system. Polysemantic adjectives under study in many cases are synonyms which are closely interrelated and interconnected. Their semantics is broad: from revealing the qualitative characteristics of people, their deeds, ways of life, behaviour and distinguishing features of character to describing the properties of being honoured, respected, recognized and acknowledged because of their spiritual and moral qualities. Componential analysis in this paper is carried out on the basis of dictionary definitions to decompose the lexical 
meanings into semes. The procedure of dividing the lexical meanings of adjectives into semes makes it possible to classify them into certain types. Some of the semes under study characterize the meanings of more than one word. This quantitative characteristics of the semes forms one of the regularities of their system and structural organization.

\section{REFERENCES}

1. Fabian M. Lexical Semantics: New Approach to its Study // Journal of Interdisciplinary Philology 2013. № 1-2. P. 5-12.

2. Geeraerts D. Theories of Lexical Semantics. Oxford: Oxford University Press, 2010. 341 p.

3. Lipka L. English Lexicology: Lexical Structure, Word Semantics and Word-formation. Tübingen: Narr, 2002. 244 p.

4. Lyons J. Language and Linguistics. An Introduction. Cambridge: Cambridge University Press, 1981. 356 p.

5. Sukhorolska S.M., Fedorenko O.I. Methods of Linguistic Analysis. Lviv: Publishing Centre of Ivan Franko Lviv National University, 2006. $342 \mathrm{p}$.

6. Ullmann S. The Principles of Semantics. Glasgow: Jackson \& Co, Oxford: Basil Blackwell, 1957. 346 p.

7. Ullmann S. Semantics. An Introduction to the Science of Meaning. Oxford: The Alden Press Basil Blackwell, 1962. 278 p.

8. Widdowson H.G. Linguistics. Oxford: Oxford University Press, 1996. $134 \mathrm{p}$.

9. Словник української мови: В 11-ти т. Київ: Наукова думка, 1970-1980.

10. Longman Dictionary of Language Teaching \&Applied Linguistics. Longman Group UK Limited, 1992.

\section{Information about the author:}

Fabian M. P.,

Doctor of Philological Sciences in General Linguistics, Professor, Professor at the English Philology Department,

Uzhhorod National University 14, Universytetska str., Uzhhorod, 88000, Ukraine 


\section{CONCEPT OLD AGE IN ENGLISH: COGNITIVE-SEMANTIC ANALYSIS}

\section{Holyk S. V.}

\section{INTRODUCTION}

Present-day developments in the fields of medicine, genetics and biomedical technologies have influenced the increase in the lifespan and older people live longer and healthier than even 50 years ago. Therefore, the problem of population ageing is gaining importance and becomes the object of interdisciplinary study.

Old age as a social phenomenon is usually defined through the prism of its medico-biological and socio-philosophical characteristics as a final stage of human life with considerable physiological and psychological changes leading to little involvement of a person in social activities ${ }^{1}$.

This research adopts a cognitive-semantic approach when meaning is defined as conceptualization. It aims at revealing the notional content of concept OLD AGE in English with the focus on the definitions of the lexeme old age in present-day lexicographical sources (both printed and on-line). Firstly, the concept of OLD AGE as a mental unit, complex knowledge cluster is analysed and its nominative field is defined. The research proves that the key lexeme old age proves to have a multicomponent semantic structure representing the period or time in life when one is old and the state or condition of being old. In the majority of studies, the nominative field of the concept is viewed as heterogeneous and consists of the nucleus and periphery. The nominative field is verbalized by direct nominative units encoding the concept and making up its nucleus, as well as nominations of separate cognitive features disclosing both the content of the concept and attitudes to it in different communicative situations (the periphery) ${ }^{2}$. Furthermore, the present study provides the cognitive-semantic analysis of synonyms to the key lexeme old age, chosen as the name of the concept.

Present-day cognitive linguists have repeatedly emphasized that the concept as an object of research requires a multidimensional methodological

\footnotetext{
${ }^{1}$ Чаграк Н. І. Соціальні теорії старіння і старості у контексті освітньої геронтології. Теоретичні питання культури, освіти та виховання : зб. наук. праць Київського національного лінгвістичного університету. 2015. № 52. С. 154-160.

2 Попова 3. Д. Когнитивная лингвистика / 3. Д. Попова, И. А. Стернин. М. : АСТ : Восток-Запад, 2007. С. 68.
} 
approach. Pimenova believes that "the concept is disseminated in the lingual signs used to verbalize it. In order to reconstruct the concept's structure, one needs to study the entire verbal corpus encoding it, i.e. lexical units, idioms, paroemias etc. ${ }^{3}$ V.Evans states that cognitive model profile is an important construct in LCCM theory (The Theory of Lexical Concepts and Cognitive Models), and it is essential to providing an account of meaning construction. ${ }^{4}$ Moreover, Evans adds that "a cognitive model is a coherent body of multimodal knowledge directly grounded in the brain's modal systems, and derives from the full range of experience types processed by the brain including sensory-motor experience, proprioception and subjective experience including affect" 5 .

\section{The Nominative Field of the Concept: the Methodology of the Research}

It is common knowledge that language is one of the basic tools of cognition and conceptualization. This means that the concept can be encoded with lingual units.

Conceptualization, being a process of human cognition, aims at capturing the content of concepts, while the concept description refers to special research procedures, including definitional, componential, contextual and etymological analyses. The composition of any concept can be revealed through dictionary definitions of lingual units used to represent it, as well as in speech contexts.

The analysis of lingual means contributes to the identification of concept's main cognitive features, the description of its content, and modelling its structure. In linguistics, there seems to be a tendency to believe that the concept is encoded with the help of the word, although the analysis at the word level reveals the most important cognitive features, but only partially. Accordingly, the analysis of concept's verbalization should be conducted at the levels of words, phrases, idioms, sentences, texts, and even non-verbal means ${ }^{6}$.

An important stage in performing the conceptual analysis is the identification of the concept's nominative field, usually based on the

3 Пименова М.В. Предисловие. //Введение в когнитивную лингвистику. Кемерово, 2004. C. 9.

${ }^{4}$ Evans V. What's in a concept? Analog versus parametric concepts in LCCM Theory. // The Conceptual Mind: New Directions in the Study of Concepts, MIT Press, 2015. P. 277.

${ }^{5}$ Evans V. Conceptual vs. Inter-lexical polysemy. An LCCM Theory Approach.// Language Learning, Discourse and Cognition: Studies in the tradition of Andrea Tyler. Eds. Pickering L., Evans V. John Benjamins Publishing House, 2018. P. 167.

${ }^{6}$ Єсипенко Н. Г. Текстові концепти та методи їх аналізу. // Вісник Волинського національного університету імені Л. Українки. Мовознавство. Луцьк : ВНУ, 2009. Вип. 5. С. 253. 
analysis of lexicographical sources. The nominative field, according to Popova \& Sternin, is defined as "a set of lingual means which express the concept at a particular time period in society and are represented by different parts of speech"7. Sternin is the first to describe the structure of the nominative field as a two-component unity with its nucleus and periphery. However, in this research the idea of nominative field subdivision into the three constituent parts (nucleus, medial zone and periphery) is applied. The notional content of the nucleus is made up of the set of sememes representing the key lexemes of the concept. Cognitive scientists state that seme analysis provides a link to the ideal sphere in language and, thus, we reveal the content of concepts and objectify their verbalization ${ }^{8}$. It is the word semantics that principally displays conceptual features. Therefore, in their studies of concepts the majority of linguists proceed from the meaning of the lingual sign to the content of the corresponding concept ${ }^{9}$. Kolegaeva assumes that the use of dictionary entries facilitates the identification of smaller lingual units, such as definitional features. These are said to be the smallest autonomous verbal constituents of the nominative field ${ }^{10}$.

In order to study concept's verbal expression, the researcher should start with the analysis of its name (or in other terminology key lexeme), followed by the analysis of its meanings. The study of dictionary definitions, said to commonly index and catalogue the language means of concept's expression, provides the researcher with the systemic choice of lexical material for further analysis.

Evans believes that "it stands to reason that representations in the linguistic system - semantic structure - is qualitatively distinct from representations in the conceptual system - conceptual structure". "From the present perspective, the linguist concludes, words are in fact cues that index or point to body-based states processed and stored by the brain"11.

Describing the stages in constructing the nominative field of any verbalized concept, cognitive linguists assume that the selection of

${ }^{7}$ Попова 3. Д. Когнитивная лингвистика / 3. Д. Попова, И. А. Стернин. М. : АСТ : Восток-Запад, 2007. С. 66.

${ }^{8}$ Бабушкин А.П. Концепты разных типов в лексике и фразеологии и методика их выявления. // Методологические проблемы когнитивной лингвистики. Воронеж: Изд-во Воронеж, гос. ун-та, 2001. С. 52.

${ }^{9}$ Алефиренко Н. Ф. Современные проблемы науки о языке: Учебное пособие. М. : Флинта: Наука, 2005. С. 183.

${ }^{10}$ Колегаєва I.M. Конструювання номінативного поля концепту: етапи та одиниці . // Записки з романо-германської філології. 2018. N 1(40). С. 122.

${ }^{11}$ Evans V. Conceptual vs. Inter-lexical polysemy. An LCCM Theory Approach // Language Learning, Discourse and Cognition: Studies in the tradition of Andrea Tyler. Eds. Pickering L., Evans V. John Benjamins Publishing House, 2018. P. 163. 
nominative units (such as, sememes together with their defenitions, collocations and phraseological units and paroemias) semantically related to the name of the concept from lexicographical sources is the first step in the research. Another stage is the definitional analysis that aims at identifying key semes which can have different definitional features in several lexicographical sources ${ }^{12}$. Similar to this idea, Nikitin specifies: "The seme is an unnominated part of the meaning"13. It is expressed via definitional features selected from dictionary entries of corresponding lexical units. The seme, being a non-material, purely semantic element, is materialized in the form of definitional features, indexed in dictionary entries. ${ }^{14}$ In addition, researchers claim that "the arrangement of key lexemes as to their notional potential provides the material of "WHAT is named, HOW it is characterized and WHAT types of transformations are observed within the field under research" 15 .

Thus, the study of concepts via language proves to be the most reliable method of linguistic analysis which helps to define conceptual features and present the concept's structure. The analysis starts with the selection of lingual units encoding the concept, and proceeds with their dictionary definitions and dicourses. The semantic features, defined in the course of the research into the meanings within the units of the nominative field, are commonly referred to as cognitive features of the concept.

\section{Definitional Analysis of the Lexeme Old Age}

The nucleus of the nominative field of the concept OLD AGE is formed by the sememes of the noun old age, which is used as the concept's name to encode it. The medial zone is represented by the derivatives of the key lexeme old age, its synonyms and free word combinations. Bound word combinations (or idioms) and paroemias constitute the periphery.

The first stage of our research is the definitional analysis which belongs to traditional methods of semantic analysis. Its main objective is to disclose the notional content of the concept as an abstract constituent through the analysis of meanings of the concept's name as indexed in different lexicographical sources.

\footnotetext{
12 Колегаєва I.M. Конструювання номінативного поля концепту: етапи та одиниці // Записки з романо-германської філології. 2018. № 1(40). С. 125.

${ }^{13}$ Никитин М. В. Курс лингвистической семантики. Санкт-Петербург: Научный центр проблем диалога, 1996. С.117.

${ }^{14}$ Смаглій В. М. Ядро номінативного поля концепту LANGUAGE. Вчені записки ТНУ імені В. І. Вернадського. Серія: Філологія. Соціальні комунікації. Том 30 (69). № 2. Ч. 1. 2019. C. 119.

${ }^{15}$ Колегаєва I.M. Конструювання номінативного поля концепту: етапи та одиниці // Записки з романо-германської філології. 2018. № 1(40). С. 126.
} 
The study of dictionary definitions, which commonly register lingual means used to represent the concept, helps to systematically select the lexical material for further research, because "despite all the weaknesses in the lexicographical procedure of defining semantic components, it still remains one of the easiest and most effective methodologies of componential analysis" ${ }^{\prime 6}$. In semasiology, dictionary definitions have been used as the source of defining word semantic components since the theoretical works by Arnold, Karaulov, Levytskii and many others. However, in terms of Sternin, dictionary definitions are not build according to the seme principle, their components require further interpretation and reformulation into the format of semes ${ }^{17}$. In this sense, he adds that preliminary generalization of dictionary definitions selected from different lexicographical sources might be an important prerequisite for further definitional analysis aimed at defining the semes. This procedure is important, since different definitions complement one another and add to the list of word meanings, as well as semantic components making up these meaning.

Moreover, dictionary definitions appear to be a sufficient and objective material to encode the structure of the word meaning. Different dictionaries provide different, both in their character and structure, definitions. According to Kubriakova, "the definitional analysis of the word and defining the structure of knowledge represented in it, as well as the conceptual analysis seem to be partially interrelated, although they represent different levels of analysis. The dictionary aims at providing such a definition that will identify the word both in the text and in discourse; cognitive analysis presents a wider scope of meanings of the nominated object and reflects knowledge necessary for understanding the object by speakers with different educational backgrounds. Usually, this knowledge is shared by a certain community. Whereas the conceptual analysis pursues the aim to define the conceptual structure which is verbalized and substantiate its verbalization” 18 .

In this chapter, I provide the analysis of the semantic structure of the key lexeme representing the concept OLD AGE. It is the noun old age, which meets the requirements for defining the name of the concept, according to Popova and Sternin, because it is a common noun, stylistically neutral, fully nominates the concept and gives material for its cognitive interpretation ${ }^{19}$. The semantic structure of the lexeme old age is

${ }^{16}$ Левицкий В.В. Семасиология. Винница: Нова книгаю 2006. С. 91.

${ }^{17}$ Стернин И. А. Методы описания семантики слова. Ярославль: Истоки, 2013.

${ }^{18}$ Кубрякова Е. С. К определению понятия имиджа / Е. С. Кубрякова // Вопросы когнитивной лингвистики. 2008. № 1. С. 8.

${ }^{19}$ Попова 3. Д. Когнитивная лингвистика / 3. Д. Попова, И. А. Стернин. М. : АСТ : Восток-Запад, 2007. С. 177-178. 
defined by selecting the sememes (or lexico-semantic variants) from dictionaries and this helps to designate the notional components of the concept OLD AGE. The definitions selected from 16 different English dictionaries and thesauri (both printed and electronic) provide the material for defining the most common meanings (sememes) forming the significatum of the concept OLD AGE. The algorithm of their compilation can vary in different dictionaries, i.e. certain meanings may occupy primary positions in dictionary entries, while, in some other sources, they could be secondary. However, what we aim at is describing the holistic picture, including the number and availability of sememes in each of the lexicographical sources under analysis.

The material of the research presents the selection from British and American dictionaries: I - Webster's New World Dictionary, II - Oxford Advanced Learner's Dictionary, III - Cambridge Dictionary Online, IV Collin's English Dictionary, V - Merriam Webster's Online Dictionary, VI Dictionary. Com, VII - MacMillan Online Dictionary, VIII - CoBuild, IX Free Dictionary, X - Oxford English Living Dictionary, XI - Urban Dictionary, XII - Wordsmyth Dictionary Online, XIII - Ultralingua, XIV Word Net Dictionary Online, XV - Your Dictionary, XVI - Longman Dictionary of Contemporary English. The research findings are shown in Table 1.

In cognitive linguistics, it is widely recognized that each sememe correlates with a particular cognitive domain. "This means that words do not represent neatly packaged bundles of meaning (the dictionary view), but serve as 'points of access' to vast repositories of knowledge relating to a particular concept or conceptual domain”, ${ }^{20}$ which proves Langacker's idea that word meanings correlate with particular cognitive structures ${ }^{21}$. Drawing on a study of Kubriakova, the meaning of a lexical unit can be regarded as " the concept captured in the word""22.

Accordingly, the analysis of dictionary definitions aims at defining those mental structures which correlate with the verbalization of the concept in native speakers' mentality. In cognitive semantics (e.g., Lakoff, Johnson, Langacker, Fillmore, Fauconnier), the meaning is usually defined as the conventional result of categorization and conceptualization processes by the representatives of certain ethnic or cultural groups. It is

\footnotetext{
${ }^{20}$ Evans V., Green M. Introduction to Cognitive Linguistics. / V. Evans, M. Green. N.Y.: Routledge, 2015. P. 160.

21 Langacker R. Foundations of Cognitive Grammar. Volume I. - Stanford: Stanford University Press, 1987. P. 99.

${ }^{22}$ Кубрякова Е. С. Язык и знание: на пути получения знаний о языке : части речи с когнитивной точки зрения. Роль языка в осознании мира : [монографія]. - М. : Язык славянской культуры. 2004. 555 с.
} 
also said to encode the experience, knowledge and feelings of people that, according to Selivanova, could contradict the reality ${ }^{23}$.

Our research results clearly demonstrate that the nucleus of the nominative field of the concept OLD AGE includes 20 sememes of the noun old age.

We proceed from the assumption that dominant meanings of the key lexeme are those which prove to be the most common in dictionary entries. The data shown in Table 1 indicate the most frequent sememes: [the time of life when one is old], [the (a) late (latter) time of life], [the period (stage) after 65], [decline of strength/health and vigor] (their usage is observed in 4 different dictionaries). These definitions might confirm the widespread idea that OLD AGE in English is viewed as the last stage or period in hum an life, usually after the age of 65 which is marked with the loss of strength (or decline) and serious health problems. According to the theory of prototypes by Rosch $(1973)^{24}$, these sememes could be regarded as prototype meanings that first come to mind when the noun old age is mentioned.

The sememes [advanced/-ing years] and [quality or state of being old/ older] proved to be less representative, although also meaningful for OLD AGE conceptualization. The data in Table 1 show that a number of different sememes, rather numerous, containing the bulk of information and characterizing OLD AGE among native speakers of English can be catalogued, but they are not frequently indexed in dictionary entries (found only in 2 out of 16 dictionaries), e.g., [the period in a person's life when one is old], [the period of your years towards the end of your life], [the last period of human life], [the later (latter) part of (normal) life], [quality or state of being towards the end of your life].

These examples suggest that OLD AGE can mostly be defined as a period in a human life, usually it is the last period, the end of the life cycle, which comes late or later in life (in comparison with another, obviously a younger period), it normally characterizes the stages of life and inevitably leads to death (or the end of life).

Also, the findings of this study reveal several unique sememes, i.e. those observed only in one of the lexicographical sources: e.g. [ideal time when you don't feel inhibited to say something embarrassing or outrageous because your days are numbered], [the part of your life when you are old], [the part after your prime], [the final stage of human life], [past middle age], [the fact of being old], [20 years older than you are], [no longer in good health].

\footnotetext{
${ }^{23}$ Селіванова О.О. Сучасна лінгвістика: термінологічна енциклопедія. Полтава : Довкілля-К, 2006. С. 305.

${ }^{24}$ Rosch E. Natural categories / E. Rosch // Cognitive Psychology. Elsevier, 1973. V. 7. P. 328-350.
} 


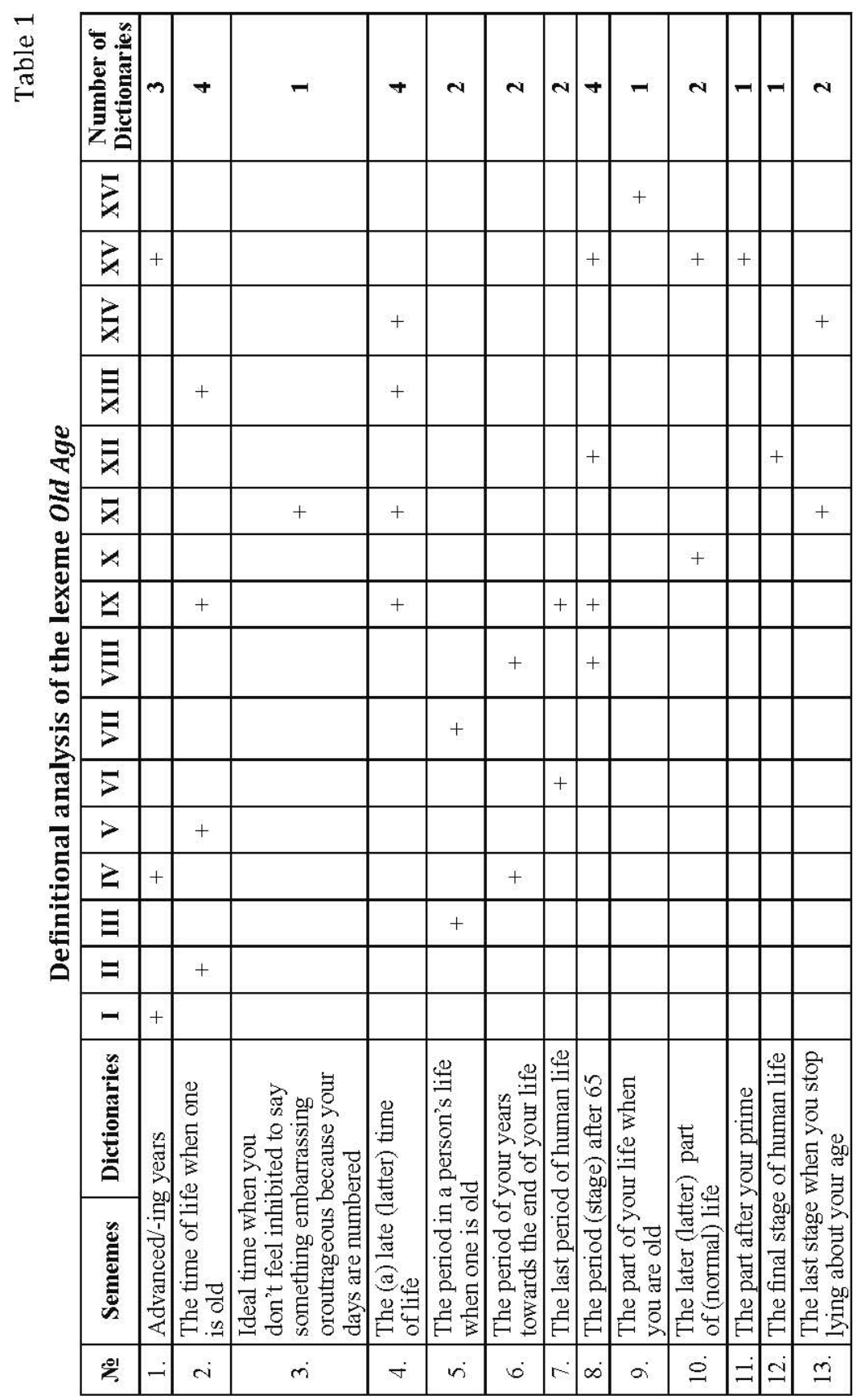




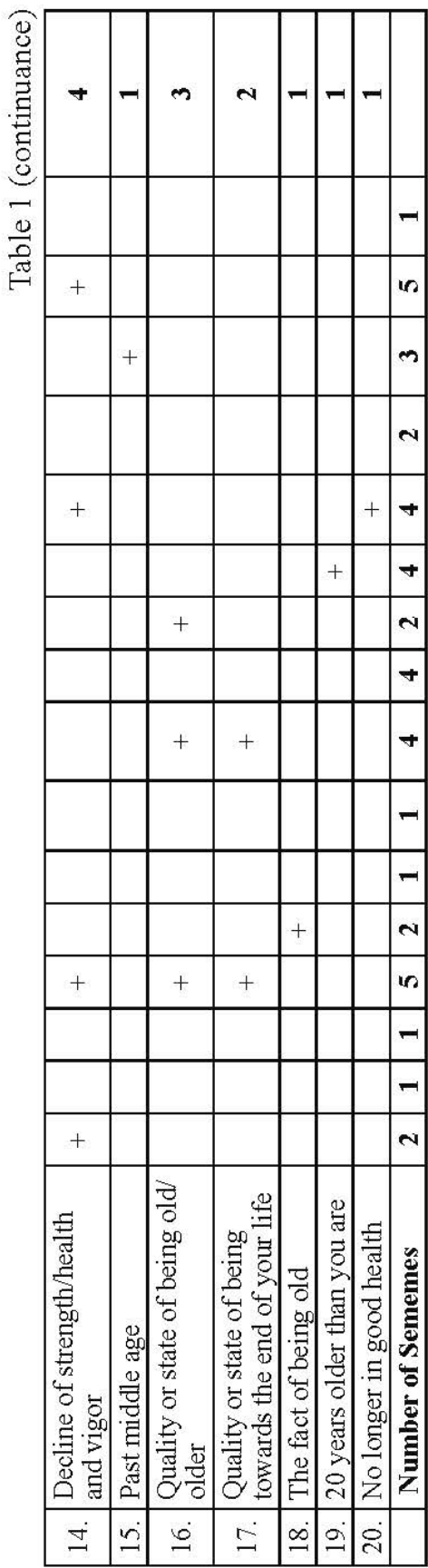

These diverse lexico-semantic variants contain very interesting definitional features. Firstly, it can be assumed that OLD AGE is categorized as a stage, time or part in life. Furthermore, the definitional features [time], [stage] and [part] are specified by providing semantic distinctions: [final stage], [part after your prime], [ideal time] etc. Thus, the conceptualization of OLD AGE in English results in presenting it as a final stage of life, following the middle age period and the person in this period becomes old or/and with serious health problems.

The list of dictionary definitions suggests that not all the components of meaning are represented in certain dictionaries. It is observed that a greater number of meanings are found only in 2 out of 16 lexicographical sources, namely in sources IV Collin's English Dictionary and XV Your Dictionary, where the lexeme old age is represented with the help of 5 sememes. The results of the definitional analysis illustrate that in 5 dictionaries, such as VIII - CoBuild, IX - Free Dictionary, XI - Urban Dictionary, XII - Wordsmyth Dictionary Online the concept OLD AGE is verbalized by means of 4 sememes. Three sememes can be identified in the structurer of the noun old age in source XIV - Word Net Dictionary Online. Other four dictionaries represent 2 lexical-semantic variants each: I- Webster's New World Dictionary, V - Merriam Webster's Online Dictionary, X - Oxford English Living Dictionary, XIII - Ultralingua. 
Similarly, only 5 sources, such as II - Oxford Advanced Learner's Dictionary, III - Cambridge Dictionary Online, VI - Dictionary. Com, VII MacMillan Online Dictionary, XVI - Longman Dictionary of Contemporary English disclose only one meaning of the lexeme old age.

The results of the preliminary analysis might serve as a basis for further subdivision of the nuclear zone of the nominative field into 2 main segments: 1) Period and 2) State.

Firstly, the segment Period implies that OLD AGE is said to be a period of human age, one of the life stages, usually the final one, the end of human life. Pimenova adds that "the conceptual structure is made up of primary (or basic) and secondary features. Basic features are verbalized in dictionary definitions of the corresponding lexeme serving as the concept's name in the form of its semantic components - semes and sememes”. In Lipka's words, the seme is a semantic feature and the sememe is defined as a "complex or configuration of semes, which corresponds to a single sense of a lexeme" 25 .

However, it is the definitional feature that could be regarded as the smallest component of the nominative field that is represented in lexicographical sources. ${ }^{26}$ Accordingly, dictionary definitions of the lexeme old age prove to comprise such common definitional features, as [period], [time], [years], [stage], [part]. For instance:

1) The definitional feature [period] is observed in the following sememes - [the period in a person's life when one is old], [the period of your years towards the end of your life], [the last period of human life], [the period (stage) after 65];

2) The definitional feature [time] is represented in the sememes - [the time of life when one is old], [the (a) late (latter) time of life], [the ideal time when you don't feel inhibited to say something embarrassing or outrageous because your days are numbered];

3) Another definitional feature [part] is found in the sememes [the part of your life when you are old], [the later (latter) part of (normal) life], [the part after your prime];

4) The definitional feature [years] is observed in the dictionary entry [advanced/-ing years] to talk about this period of human life;

5) Finally, the definitional feature [stage] is highlighted when old age is defined as [the final stage of human life], [the last stage when you stop lying about your age and start dragging about it], [the stage after 65].

${ }^{25}$ Lipka L. English Lexicology: Lexical Structure, Word Semantics and Word-Formation. Gunter Narr Verlag, 2002.

${ }^{26}$ Колегаєва I.М. Конструювання номінативного поля концепту: етапи та одиниці // Записки з романо-германської філології. 2018. № 1(40). С. 122-123. 
In this research, we hypothise that the main feature - [period] - is further specified and clarified in the definitions of every sememe, thus adding to the nuclear zone of the concept OLD AGE. The seme Period is complemented with the qualificational semes that explain the nature of this period. Consequently, it is [last period], [end of life], [final stage], [advanced years], [last stage], [late (latter) time]. These semes (in italics) describe OLD AGE as the end of human life, its last or late/later period. Relative qualificational semes chronologically refer the period to a certain point in time: e.g., the period when you reach 65 [the period after 65]. Conversly, the feature [past middle age] defines it as following the middle age period without mentioning the exact chronological age.

Relative qualificational feature [part after prime] leads to understanding old age as the period of decline which comes after the period of the greatest strength or vigour, consequently it helps to reveal negative evaluative component in the semantic structure of the lexeme old age.

There is also a unique definition of old age in Urban Dictionary [20 years older than you are]. This sememe defines old age by applying a relative feature [20 years older] and comparing this period with the speaker's age. This leads to understanding that anyone, who is 20 years older than you are, is believed to be old. Due to this fact, the beginning of old age is not linked to a chronological age, but is rather floating, when "being aged" means "being older than yourself". Such approaches are especially typical of the younger generation and might represent some of the social ageist attitudes. Moreover, the example in Urban Dictionary is used to explain that old age is not fixed to a certain age, not "demarcated as the period of life occurring after sixties or seventies" ${ }^{27}$, on the contrary, it is a flexible notion: e.g. "When you are 10, 30 is old. When you reach 30,50 seems old. When you reach 50,70 seems old and so on. So it is a shifting scale where nobody ever thinks they are old"28.

Also, the interpretation of dictionary definitions discloses one more characteristic feature of OLD AGE when it can be treated as an ideal time. The definitional feature [ideal time] is used to conceptualize the period when you are free to express your feelings and emotions. Sememes 3 and 13 (see Table 1), in a rather extravagant way, define the lexeme old age, adding to its evaluative component of meaning, because it is a period which makes you free in your expressions, no more limits and taboos [stop lying about your age] and one can be really abusive - [don't feel inhibited to say something embarrassing]. And the reason for this is that

\footnotetext{
${ }^{27}$ New definition for old age. Science Daily. URL: https://www.sciencedaily.com.

${ }^{28}$ Urban Dictionary. https://www.urbandictionary.com.
} 
[your days are numbered] and you no longer depend on or care about social norms of behaviour accepted in your community.

The nucleus of the concept OLD AGE includes another segment State, with the definitional features [state], [quality] and [fact]:

1) The [state] proper and [quality] - [quality or state of being old/ older], [quality or state of being towards the end of your life];

2) Existential feature [fact] - [the fact of being old];

3) The state of having health problems and related issues - [no longer in good health], [decline of strength/health and vigor].

The sememes mentioned above provide the definitions of old age by using the adjective old - the state, quality, fact of [being old/older]. As Evans (2015) suggests, the grammatical distinction between the adjective and noun appears to relate to a semantic distinction between the notion of property versus thing. ${ }^{29}$ The words old and old age, while indexing the same (or similar) perceptual state, also encode schematic concepts: property versus thing. Thus, old age might be regarded as the property of being old. This contributes to disclosing the notional component of OLD AGE concept by the stylistically neutral lexical unit old as a constituent of its nuclear zone (which could be the object of further research).

Another conceptual feature in this segment is represented by the sememe [decline of strength/health and vigor], specifying old age as a state of poor health because of being old. This semantic component of meaning proves the dominant ageist stereotype when being old equals to being seriously ill, when ageing is usually viewed as a process of inevitable decline (e.g., Gual, 2015) ${ }^{30}$. The analysis of the dictionary definitions demonstrates that old age is regarded as the state when your health is no longer strong enough, you are feeble and in poor condition.

\section{The Synonyms to the Noun Old Age: Cognitive-Semantic Analysis}

A very important stage in our research is cognitive-semantic analysis of synonyms to the key lexeme, which are subdivided into the corresponding synonymic groups: the temporal group Life Period, representing old age as a life stage/period, and the classificational group State, expressing a qualitative feature.

${ }^{29}$ Evans V. What's in a concept? Analog versus parametric concepts in LCCM Theory. // The Conceptual Mind: New Directions in the Study of Concepts, MIT Press, 2015. P. 271.

${ }^{30}$ Gual N. Ambivalent Pathways of Progress and Decline: The Representation of Aging and Old Age in Joanna McClelland Glass's Drama. // Theatre Research in Canada / Recherches théâtrales au Canada, 2015. 36 (1). 
The first synonymic group Life Period characterizes old age as a period in human life. The analysis of individual dictionary definitions of the synonyms helps to define their common definitional features [period, years, time, stage, age], which are further specified. These verbal units can be grouped as to their semantic components:

1) The first group encodes old age as the period when one is old or elderly: e.g., advanced /advancing years [the period of being elderly], agedness [the period of advanced years], ageing [growing older], Anno Domini [advancing old age] informal, autumn of one's life [the period of being elderly, old age], elderliness [the stage of life well past middle age], evening of one's life [the period of being elderly], oldness [period of being elderly].

These synonyms provide a neutral characteristic of old age, describing it as a life period with the generalized meaning when a person is old, elderly or in advanced years. The analysis of these sememes helps to highlight the definitional features [old], [elderly], [past middle age], [advanced years], [advancing].

2) The second group represents OLD AGE as the final stage of life, the last years of age: age [a late time of life, the latter years of life], decline [the last part of life], declining years [the last years of someone's life], eld ${ }_{\text {archaic }}$ [a late time of life], extremity [the end of life, dying] archaic, Fourth Age [starting at about age 80 or 85, includes the last years of adulthood], geezerhood [a late time of life], senectitude [the final stage of normal life span], twilight/twilight years [the last years of life], winter of one's life, years [a late time].

The analysis of dictionary definitions of the synonymic units in this group reveals a negative-evaluative semantic component of their specificational definitional features - [the final stage], [the last years], [the last part of life], [a late time], [the end of life, dying]. The semes final, last, late, end provide the verbalization of what is labelled as "decline ideology", ${ }^{31}$ i.e. the prevailing social attitude to old age and ageing as the last period, the last stage in the lifespan when old age is considered to be a problem causing decline. Furthermore, the lexeme extremity, with archaic stylistic connotation, encodes the meaning of dying, thus representing a gloomy picture of old age that inevitably leads to death. The lexeme Fourth Age defines old age chronologically as the period starting at about age 80 or 85 . Sociologists state that " $<\ldots>$ the fourth age embodies all the fears of old age; it brings fragility, helplessness and loss of autonomy”, ${ }^{32}$.

\footnotetext{
${ }^{31}$ Gullette Margaret M. Aged By Culture. Chicago: University of Chicago Press, 2004. P. 7.

${ }^{32}$ Petrová Kafková M. The „Real“ Old Age and the Transition between the Third and Fourth Age / Sociológia 48, 2016. № 6 . P.623.
}

64 
For active people in the third age, fourth agers represent „the others“ ${ }^{33}$. Moreover, they suggest a dual view of old age, discriminating between the concepts of the young-old and old-old, e.g. Neugarten (1974). ${ }^{34}$ However, it is Laslett who introduces the terms "third and fourth age" and characterizes the fourth age as a period of final infirmity, decrepitude and death $^{35}$. Thus, the sememe [starting at about age 80 or 85 , includes the last years of adulthood] indexes not only the chronological marker $80+$, but also the evaluative connotational feature of decline.

The lexeme senectitude originates from Latin senect( $\bar{u} s)$ meaning “old age" and is first recorded in English in the period 1790-1800. The dictionary definition shows the specificational definitional feature [the final/last stage].

Another group of synonyms describes OLD AGE as the period of delight, happines and enjoyment of life: e.g., green old age [a period when you might not be able to do all the things you used to do, as well as you used to do them, but there are also likely to be fewer demands on you and less stress], Indian Summer [the final period of a person's life regarded as tranquil, serene], [a pleasant or successful time nearly at the end of your life].

Firstly, we can observe the presence of the hyperseme period in these sememes together with its equonymic seme time. Also, these semes are specified with the definional features [tranquil, serene], [pleasant or successful], [fewer demands on you and less stress], which help to reveal positive evaluative component in the semantic structure of the nominative units green old age and Indian Summer. This goes in line with "the narrative of success ignoring the physical dimensions of aging” (Gual 2005) and the notion of "successful aging" that combines life satisfaction, happiness, good health and longevity.

Moreover, a number of synonyms describe old age chronologically by decades: sixties [the period when a person is aged from 60 to 69], seventies [the period when a person is aged from 70 to 79], eighties [the period when a person is aged from 80 to 89], nineties [the period when a person is aged from 90 to 99]. The seme period is specified in each of these sememes by indicating the corresponding decade [from 60 to 69], [from 70 to 79], [from 80 to 89] and [from 90 to 99].

${ }^{33}$ Gilleard C., Higgs P. Cultures of Ageing: Self, Citizen, and the Body. Essen: Perason Education, 2000.

${ }^{34}$ Neugarten B. L. Age Groups in American Society and the Rise of the Young-Old. // The ANNALS of the American Academy of Political and Social Science, 415 (1), 1974. P. 187-198.

${ }^{35}$ Laslett P. A Fresh Map of Life: The Emergence of the Third Age. Harvard University Press, 1991. 
A special attention should be paid to stylistically neutral lexemes of Latin origin representing OLD AGE chronologically: e.g., sexagenarianism [the state of being sexagenarian], septuagenarians [the state of being septuagenarian], octogenarianism [the state of being octogenarian], nonagenarianism [the state of being nonagenarian]. Further definitional analysis reveals the onomasiological basis of these lexical units, used to denominate a state of a person whose age is in the sixties (sexagenarian - from Latin sexagenarius of or containing sixty, sixty years old), seventies (septuagenarian - from Latin septuagenarius of or containing seventy, seventy years old), eighties (octogenarian - from Latin octogenarius containing eighty), nineties (nonagenarian - from Latin nonagenarius containing ninety).

One of the prevailing social perceptions of old age and older adults is that they are retired and receive pensions from the government. This meaning is encoded in the following synonymic units: e.g., golden years [the time of life retirement from active work], [the years after the retirement], pension (pensionable) age, retirement [the years after retirement]. The semes time, years are specified as the the time of [retirement from active work], [after retirement] with the hyponymic seme retirement encoding the meaning of the period when a person stops working. The definitions of the synonym golden years [the term used by old folks who are too attached to their youth to admit that they are in fact: old, senile, and wrinkly], [the ages during retirement toward the end of one's life, but enough to still enjoy the remainder; typically 65 and up] in the entries of Urban Dictionary index old age, pointing to its positive and negative aspects simultaneously. On the one hand, the definitional features [attached to their youth], [still enjoy] encode the semantic component of enjoyment with the verb enjoy and the period when a person still feels young by using the antonym youth. On the other hand, the definitional features [the ages during retirement] [old, senile, and wrinkly], [toward the end of one's life] add to the negative evaluation of old age. Also, the definitional feature [typically 65 and up] defines the chronological limits of old age.

Lexical units within the synonymic group State represent old age in different ways.

Firstly, it is defined as the state of being old: e.g., age [the state of being old or becoming old], advanced age [the age of someone who is old], antiquity [great age], elderhood [the state, quality, or condition of being an elder], geromorphism [a condition of appearing prematurely old or aged], grand old age [the state when a person is very old], senescence [the state of being old, aged]. As a result of the definitional analysis the seme state with its equonyms quality, age, or condition is revealed in 66 
every sememe, and it is specified by means of hyposemes old, elder, aged. Thus, all these synonyms index old age as the state when you are old/aged/elder. The definitions of the nominative units antiquity, geromorphism, grand old age include the evaluative definitional features [prematurely old or aged], [very old], [great age] expressing the intensifying connotational meaning.

A great number of synonyms define old age as a state of being ill: Alzheimer's disease [showing poor mental health; a loss of mental faculties because of old age], [deterioration of mental faculties], anecdotage [old age, especially in someone who is inclined to be garrulous], [senility, as characterized by the telling of rambling anecdotes], anility [the condition of behaving like an old woman, used especially of men], [the quality resembling a doddering old woman; old-womanishness; dotage], caudicity [senility - physical and mental decline associated with old age], decay [deterioration], dementia [a state of serious mental deterioration], dotage [mental infirmity as a consequence of old age shown by foolish infatuations]; [feeble and childish state due to old age]; [senile decay marked by decline of mental poise and alertness], infirmity, senility [the quality of being senile, i.e. showing poor mental ability because of old age]; [confused, unable to look after themselves, no longer remember things], second childhood [when someone starts to behave like a child, esp. because of mental weakness caused by old age], sundowning [agitation or anxiety at night by elderly patients].

All these sememes are characterized by the presence of the hyperseme state or its synonyms condition and quality that are specified with the qualificational features [poor mental health], [a loss of mental faculties], [deterioration of mental faculties], [mental infirmity], [being senile], [mental weakness], [no longer remember things], [poor mental ability], [mental decline], [decline of mental poise and alertness]. These semantic components encode the social stereotypes and focus on age related diseases, primarily mental decline, contributing to a negative ageist view of old age as a state of deterioration and decadence. Negative components of meaning in such definitional features [confused, unable to look after themselves], [foolish infatuations], [doddering old woman] are quite obvious and these units provide the verbalization of the negative perception of old age. Two synonymic units, second childhood and dotage, compare old age with another life stage, the period of childhood, by providing the definitional features [childish state], [behave like a child]. This also helps to disclose another conceptual feature of old age, such as dependence, similar to children who usually depend on their parents or guardians. The lexical unit anecdotage is defined as [old age, especially 
in someone who is inclined to be garrulous], [senility, as characterized by the telling of rambling anecdotes] with the specificational features [garrulous] and [the telling of rambling anecdotes] which at the second level of definitional analysis are defined as [excessively talkative, especially on trivial matters] and rambling [lengthy and confused or inconsequential]. Thus, anecdotage is used to index that constituent part of the concept OLD AGE which labels it derogatorily.

Also, one of the synonyms coined not long ago (the earliest mention in 1986) ${ }^{36}$ is sundowning which refers to the state of anxiety and agitation or nervous excitement and is said to be the symptom of Alzheimer's disease and other forms of dementia. Merriam-Webster's Dictionary gives the following medical definition [a state of increased agitation, confusion, disorientation, and anxiety that typically occurs in the late afternoon or evening in some individuals affected with dementia] ${ }^{37}$. The specificational features explicitly index old age as the state of serious illness, with the semes confusion, disorientation and anxiety adding to its negative psychological and emotional characteristics.

The biomedicalization of old age has led to its categorization as the state of weakness. The following goup of synonyms are united on the basis of this specificational feature: decline [smb's old and becoming weaker], decreptitude [the state of being old and no longer in good condition or health $]_{\text {formal }}$, feebleness [the state of being physically and mentally weak], infirmity [poor or deteriorated vitality because of old age], sarcopenia [the age related loss of muscle mass and strength], weakness [the state or condition of lacking strength]. The definitional features [becoming weaker], [no longer in good condition], [being physically weak], [poor or deteriorated vitality], [lacking strength], [loss of strength] altogether verbalize the conceptual feature of weakness as a state because of old age.

The sememes of another group of synonyms in their unity represent old age as associated with changes in appearance, the bodily marker of ageing, such as greying: e.g., grey hairs [a lightening of the hair caused by aging, old age], greying [the state or process of becoming old], hoariness [the state of being grey or white with age]; [the state of being white or whitish]. The examples above show that their common specificational definitional features is [grey] with its hyponyms [lighting/white/whitish].

However, the analysis proves that some of the synonyms have sememes that represent OLD AGE positively as longevity, experience, possibility for self-development, respect and active lifestyle. Together they

\footnotetext{
${ }^{36}$ Word Spy. https://www.wordspy.com/index.php?word=sundowning).

${ }^{37}$ Merriam Webster's Dictionary. https://www.merriam-webster.com\%2Fmedical\%2Fsundowning.
} 
constitute the conceptual domain Experience/Maturity with the definitional features - [experience], [maturity], [longevity], [being energetic/in good health]: e,g., experience [knowledge or skill in a particular job or activity, which you have gained because you have done that job or activity for a long time], longevity [advancement, continuence]; [living for a long time], maturity, matureness [state of being mature]; [full development], a ripe old age [the condition of being very old, used to talk about someone who has a long healthy life], seniority [the state of being senior; priority of birth; superior age], sprightliness [the quality of being energetic and in good health, especially when you are old],Third Age [old age with opportunities to travel and further education].

\section{CONCLUSIONS}

This research follows the cognitive-semantic paradigm which has already become traditional in defining the notional content of verbalized concepts. The analysis of the dictionary definitions demonstrates that the nucleus of the nominative field of the concept OLD AGE is made up of twenty sememes. The preliminary analysis might serve as a basis for further subdivision of the nuclear zone into two main segments that can be named as Period and State. Accordingly, dictionary definitions of the lexeme old age prove to display such common definitional features, as [period], [time], [years], [stage], [part] within the segment Period and [state], [quality], [fact] + being old/older, and [decline] + because of old age] in the segment State.

The results described are fairly general, however they show that OLD AGE in English is constructed in different ways: chronologically; as a social construct; the age of longevity, wisdom and life satisfaction, confirming the theory of "successful ageing"; adopting a purely biomedical approach and indexing OLD AGE as a period of decline, mental and physical weakness; and also as a retirement period.

Cognitive-semantic analysis of synonyms, making up the medial zone of the nominative field, results in dividing them into similar synonymic groups: the temporal group Life Period, representing OLD AGE as a life stage/period, and the classificational group State, expressing a qualitative feature.

This research provides implications for further study of old age and ageing individuals in different types of discourses. This can help not only to specify the notion of old age as a lingual-cultural phenomenon, but also provide criteria for defining the conceptual model of OLD AGE in English. 


\section{SUMMARY}

The present research deals with the study of the concept OLD AGE in English with the focus on the analysis of the lexical unit old age used as its name. The topicality of such works is quite obvious, since the concept has recently become an object of a multidimensional linguistic study. Research material has been selected from present-day lexicographical sources with the analysis of dictionary definitions, as well as componential analysis. Furthemore, one issue of this study is the cognitive-semantic analysis of synonyms to the key lexeme old age. The research findings provide implications for further studies of this concept in different types of discourse that will contribute to a deeper understanding of old age as a lingual-cultural phenomenon and provide criteria for defining the conceptual model of the concept OLD AGE.

\section{REFERENCES}

1. Evans V. Conceptual vs. Inter-lexical polysemy. An LCCM Theory Approach.// Language Learning, Discourse and Cognition: Studies in the tradition of Andrea Tyler. Eds. Pickering L., Evans V. John Benjamins Publishing House, 2018. P. 159-190.

2. Evans V. What's in a concept? Analog versus parametric concepts in LCCM Theory. // The Conceptual Mind: New Directions in the Study of Concepts, MIT Press, 2015. P. 251-290.

3. Evans V., Green M. Introduction to Cognitive Linguistics. / V. Evans, M. Green. N.Y.: Routledge, 2015.

4. Gilleard C., Higgs P. Cultures of Ageing: Self, Citizen, and the Body. Essen: Perason Education, 2000.

5. Gual N. Ambivalent Pathways of Progress and Decline: The Representation of Aging and Old Age in Joanna McClelland Glass's Drama. // Theatre Research in Canada / Recherches théâtrales au Canada, 2015. 36 (1).

6. Gullette Margaret M. Aged By Culture. Chicago: University of Chicago Press, 2004.

7. Langacker R. Foundations of Cognitive Grammar. Volume I. Stanford: Stanford University Press, 1987.

8. Laslett P. A Fresh Map of Life: The Emergence of the Third Age. Harvard University Press, 1991.

9. Lipka L., English Lexicology: Lexical Structure, Word Semantics and Word-Formation. Gunter Narr Verlag, 2002.

10. Neugarten B. L. Age Groups in American Society and the Rise of the Young-Old. // The ANNALS of the American Academy of Political and Social Science, 415 (1), 1974. P. 187-198. 
11. New definition for old age. Science Daily. URL: https://www.sciencedaily.com.

12. Petrová Kafková M. The „Real“ Old Age and the Transition between the Third and Fourth Age / Sociológia 48, 2016, № 6. P. 622-640.

13. Rosch E. Natural categories / E. Rosch // Cognitive Psychology. Elsevier, 1973. - V. 7. - P. 328-350.

14. Алефиренко Н. Ф. Современные проблемы науки о языке: Учебное пособие. М. : Флинта: Наука, 2005. 416 с.

15. Бабушкин А.П. Концепты разных типов в лексике и фразеологии и методика их выявления. // Методологические проблемы когнитивной лингвистики. Воронеж: Изд-во Воронеж, гос. ун-та, 2001. C. 52-57.

16. Єсипенко Н. Г. Текстові концепти та методи їх аналізу. // Вісник Волинського національного університету імені Л. Українки. Мовознавство. Луцьк : ВНУ, 2009. Вип. 5. С. 253-257.

17. Колегаєва I. М. Конструювання номінативного поля концепту: етапи та одиниці // Записки з романо-германської філології. 2018. № 1(40). С. 121-127.

18. Кубрякова Е. С. Язык и знание: на пути получения знаний о языке : части речи с когнитивной точки зрения. Роль языка в осознании мира : [монографія]. - М. : Язык славянской культуры. 2004. $555 \mathrm{c}$.

19. Кубрякова Е. С. К определению понятия имиджа / Е. С. Кубрякова // Вопросы когнитивной лингвистики . 2008. № 1. С. 5-12.

20. Левицкий В.В. Семасиология. Винница: Нова книга. 2006. 512 c.

21. Никитин М. В. Курс лингвистической семантики. СанктПетербург: Научный центр проблем диалога, 1996. 760 с.

22. Пименова М. В. Предисловие. // Введение в когнитивную лингвистику. Кемерово, 2004. 208 с.

23. Попова 3. Д. Когнитивная лингвистика / 3. Д. Попова, И. А. Стернин. М. : АСТ : Восток-Запад, 2007. 314 с.

24. Селіванова О.О. Сучасна лінгвістика: термінологічна енциклопедія. Полтава : Довкілля-К, 2006. 716 с.

25. Смаглій В. М. Ядро номінативного поля концепту LANGUAGE. Вчені записки ТНУ імені В. І. Вернадського. Серія: Філологія. Соціальні комунікації. Том 30 (69). № 2 Ч. 1. 2019. С. 119-123.

26. Стернин И. А. Методика исследования структуры концепта // Методологические проблеми когнитивной лингвистики: научное издание / Под редакцией И. А. Стернина. Воронежский государственный университет, 2001. С. 58-65. 
27. Стернин И. А. Методы описания семантики слова. Ярославль: Истоки, 2013.

28. Чаграк Н. І. Соціальні теорії старіння і старості у контексті освітньої геронтології. Теоретичні питання культури, освіти та виховання : зб. наук. праць Київського національного лінгвістичного університету. 2015. № 52. С. 154-160.

\section{SOURCE MATERIAL}

1. Cambridge Dictionary. https://www.dictionary.cambridge.org

2. Collins English Dictionary. Co Build. https://www.collinsdictionary.com

3. Dictionary.com. https://www.dictionary.com

4. Longman Dictionary of Contemporary English. https://www.ldoceonline.com

5. Macmillan Dictionary. https://www.macmillandictionary.com

6. Merriam Websters Dictionary. https://www.merriam-webster.com

7. Oxford English Living Dictionary.

8. Oxford Advanced Learner's Dictionary.

9. https://www.oxfordlearnersdictionaries.com

10. The Free Dictionary. https://www.thefreedictionary.com

11. Ultralingua https://www.ultralingua-dictionary.e.softonic.com

12. Urban Dictionary. https://www.urbandictionary.com

13. Webster's New World Dictionary of American English / Ed. V. Neufeldt. N.Y.: Prentice Hall, 1994. 1570 p.

14. Word Net Dictionary Online. https://www. wordnet.princeton.edu 15. Word Spy. https://www.wordspy.com

16. Wordsmyth Dictionary Online. https://www.wordsmyth.net

Information about the author: Holyk S. V., Candidate of Philological Sciences, Associate Professor, Head of the English Philology Department of the State University "Uzhhorod National University” 14, Universytetska str., Uzhhorod, 88000, Ukraine 


\section{TRANSLATING CULTURALLY MARKED VOCABULARY}

\section{Palchevska O. S.}

\section{INTRODUCTION}

The problem of the relations and connections of the language, culture and ethnicity is an interdisciplinary one and the only possible way to resolve it lies in the attempt to join efforts of several sciences, including linguistics and translation. It is not new. Cultural studies are now regarded not just as an allied sector of linguistics, but as a phenomenon without the analysis of which one can not comprehend the mystery of man as well as the mystery of the language and text. And that is why the problem of translating the folk texts (folklore texts) culturally marked lexicon arises as an indispensable phenomena for understanding the source culture.

Term folklore as a notion was coined by Briton William John Thoms who, in 1846, proposed that the Anglo-Saxon compound folklore be used instead of the Latinate popular antiquities to describe "the manners, customs, observances, superstitions, ballads, proverbs" and other materials "of the olden time" ${ }^{1}$.Thus Folk texts are mainly described as the texts of the unwritten literature as expressed in folk tales, proverbs, riddles, songs, etc $^{2}$. The folk text carries the inscriptions of cultural coding in the form of myths, legends, symbols, fantasy and dreams of the source culture. The problem of understanding the folk text or (folklore text) lies in the sphere of understanding cultural identity of a certain nation. Thus the folk text carries the inscriptions of cultural coding in the form of myths, legends, symbols, fantasy and dreams of the source culture. The main problems the translator of the folklore text overcomes are generally connected with the translation of the lacunae or culturally marked lexical units.

Lacunae (culturally marked lexical units) are considered as the main difficulty for rendering from one language into another. Under lacunae vocabulary we understand lexical units that have no verbal equivalent in one of the languages being compared, due to the absence or concepts in a certain lingvoculture or lexical unit expressing this concept. The definition implies that the main lacunae vocabulary complexity is its

${ }^{1}$ McCormick Ch., White K. Folklore. An Encyclopedia of Beliefs, Customs, Tales, Music, and Art, ABC-CLIO 2010.

${ }^{2}$ Collins English Dictionary. Available online: http://www.collinsdictionary.com/dictionary/ english. 
untranslatability, which results in a process of the semantic presentation of these lexical units. Thus, in order to demonstrate the meaning of gaps, translators need to think carefully on the semantization techniques.

\section{Translation and culture}

There are lots of definitions on language which are included here shortly. Language is used to maintain and convey culture and cultural ties. Different ideas stem from differing language use within one's culture and the whole intertwining of these relationships start at one's birth. Language may refer either to the specifically human capacity for acquiring and using complex system of communication or to a specific instance of such a system of complex communication. The human language faculty is thought to be fundamentally different from and of much higher complexity than those of other species. Human language is highly complex in that it is based on a set of rules relating symbols to their meanings, thereby forming an infinite number of possible innovative utterances from a finite number of elements.

Culture is defined culture as the way of life and its manifestations that are peculiar to a community that uses a particular language as its means of expression. It is clearly stated that operationally he does not regard language as a component or feature of culture in direct opposition to the view that stated that language is part of a culture.

The term culture originally meant the cultivation of the soul or mind; culture includes behavior such as courtship or child rearing practices material things such as tools, clothing and shelter, institutions and beliefs. Culture is the sum total of the ways of living built up by a group and passed on from one generation to another. Culture is a complex whole which includes knowledge, belief, art, law, morals, customs and many other capabilities and habits acquired by man as a member of society.

The communication of the meaning of the source-language text is by means of an equivalent target-language text so translation consists of language and culture. Jerome said that two things are necessary for a good translation - an adequate understanding of the original language (source language) and an adequate command of the language into which one is translating (receptor language). Translation is a complicated process. However, a translator who is concerned with transferring the meaning will find that the receptor language has a way in which the desired meaning can be expressed, even though it may be very different from the source language form. Translation is no longer considered to be a mere crosslinguistic activity but it significantly is cross-cultural communication. 
We came to agree on the existence of the so-called "cultural universals" that enhance communication, change of ideas in order to achieve progress in all life domains. Change of ideas, concentration of mutual efforts in different directions, communication among different peoples in different ways, all these are a constant necessity of spiritual and material life. Not only cultural acts are achieved by means of continuity process alone, but also being discontinuous can be as creative at certain times. Yet, this breach is to be performed to existent models and not to a state of nothingness. But how cultures transfer through the languages? For answering this question we should consider the relationship between culture and language which is deeply rooted. Translation is the only way which does it. The fact that there is only one human species is explained by the possibility to transfer sense, meaning from one language to the other, by means of the word, thus, by translation. But during translation process there are some barriers that are discussed as follows: There are some obstacles which effect culture transferring through different languages such as limitation and censor, culture, religion, etc.

Limitation and Censor Traditionally, there is something which is lost in translation process. Limitation and censor as obstacles that limit translators in conveying the "semantic" message in the receptor language.

The other limiting factor which translators encounter is moral filtering being based on religion, family, society rules, and 84 culture, etc. Moreover limitation related to different kinds of the audience. So it is the time to say that culture itself is a filter in translation.

Culture Difficulties arising out of differences of cultures constitute the most serious problems for translators and have produced the most farreaching misunderstanding among readers.

Culture itself has its own limitation in transferring the source text into target text. Each society or group of people based on their historical background, local situations, and religion with their specific language, construct their own culture which is respected, performed and accepted along with its limitations. Limitation in translation is one of the specific features of culture, not necessarily imposed from outside world. Behaviors which are acceptable will vary from location to location.

Nowadays, the major problem in translation is being certainly influenced by different cultural norms in the source language and target language. The translator's responsibility is to choose the norms that take priority over others. It depends on translator's decision if the cultural norms of the source language, target language, or a combination of both are essential to be considered. 
Religion is one of those obstacles that cause problem in translation. Religion can be understood only by its cultural language and to translate this religious context we face with some limitations that cannot be translated. Because religious texts are described in an implicit way, natural and effective translation is almost impractical. Besides, religion and culture are interwined and religion has taken its root from human mind and soul, people accepte them by the core of their hearts. Therefore, it cannot be changed or distorted by any one. because it leads to stimulate people and evoke negative reaction by them. Therefore translators' job is more difficult and must avoid such distortion or any work which is against their religion in the process of translation.

We talked about the limitations of translation process but let's add that translation not only transfers fundamental aspects and features of culture but also it transfers modern science, and foreign histories. Therefore, that a translator's job is to eliminate and destroy boundaries is not always true. It crosses the borders to communicate cultures.

Translation plays a vital role in making a culture universal and general. It acts as a bridge to communicate all kinds of languages specially those similar to each other considering their linguistic features and cultural customs in all parts of the world. So it links all units of the world in the global network. Moreover translation presumes the existence of boundaries between different cultures and the translator most probably is aware of these boundaries and the inevitability of crossing them. Without cultural similarities and universalities, there is no way for people of different cultures to communicate with each other and translation will be impossible. When speaking of two languages which are to be translated equivalently, translators must convey the same referential, pragmatic and interlinked meanings. However, due to differences between two cultures, semantic equivalence is limited to some.

Pop culture develops within human's growth which some of those pop culture's would be a part of our life way. Since translation transfers the culture, unconsciously behind this culture, we get familiar with the pop cultures and people's habits of different regions. For example, "Mother Day" as a pop culture shows that people respect Mothers. So this special day has become a habit for all countries in different geographical regions. Also daily habits such as using the Internet have become so common globally so using this is inevitable almost for all.

Each language has its own culture and religion. Each society propagates its own specific culture through translation. Culture translation helps to know the variety of worship of different cultures. For e.g. Muslim pray in Masque, Christian in Church, Jewish in Synagogue or celebrating 
"Christmas Day" has been expanded. Thus, translation link cultures as a chain. Thus translation obviously is a cross-cultural communication; it is beyond structures and sentences, and not simply a mere language.

A proper translation makes the reader to ponder over the cultural context of the source language. Cultural borrowing is one of the advantages that transfer ideas, customs, and social behaviors from another culture. By an adequate translation readers or audience of target language culture will acquire a lot of useful benefits for e.g. hospitality; way of greeting and saying hello when they meet each other in Iran would be extend in the world through translation. The other e.g. is table manner of some nations that reflect how that nation's culture is.

The specific ways of such culturally marked lexical units translation can be reviewed through figurative categories used in folk vocabulary (metaphor, simile, connotation).

In case of translation with the absence of translation equivalents, i.e. when in the target linguvoculture the corresponding concept or linguistic sign with a similar tradition of use doesn't exist, it is practically impossible to establish the relationship between the folklore nomination and its translation equivalents. In this regard, we should speak of asymmetry and homology (a structural semantic 'resonance' between the different elements or similarity with the fundamental differences), or of a conflict "quasiequivalence" (the term Yuri Sorokin) ${ }^{3}$.

As to the translation techniques we may consider the follows:

1) the replacement of the source word (phrase) by the corresponding equivalent of the target language;

2) the interpretation, in which in addition to the equivalent in the target language translators give the information about the coincidence (or divergence) in the cultural component of meaning.

The translation of the great amount of the lacuna lexicon is frequently based on the methods of transcription / transliteration as well as by means of the semantic translation or modeling words and constructions after foreign patterns (e.g. personal, geographical names, mythological concepts so on).

This very often results in appearance of the target language words having just similar sound-graphic form, but not correlating neither to the source language notion, nor to the concept.

In case of semantic translation the lexical units of the target language are used. The problem is that such equivalents have just the close translational correspondence of meaning with the absence of conceptual content.

\footnotetext{
${ }^{3}$ Сорокин Ю.А. Переводоведение: статус переводчика и психогерменевтические прочедуры. - Москва, 2003.
} 
In this regard the main interlanguage and intercultural complications caused by the translation on micro- and macro- levels have been noted. Translation transformations aiming to overcome different kinds of complications, may either lead to the meaning loss or to semantic increments in the target text.

Lingvocultural determination of the folk units initially sets the the folk unit asymmetry in different folk traditions, reflecting the cultural identity of the mental categorization and conceptualization processes.

Language complications on the lexical level arise due to mismatch between the meanings of words, lack of semantic differentiation, different pragmatic potential of words in source and target languages, the similar notion lack or absence of interlanguage correspondences.

For example, the pragmatic potential of folklore and mythological contexts is different and the words having the equivalents in source and target languages have different associative realities: піч - сидіти на печі (stove - he would sit on the stove), пампушка - cake, стодола, клуня shed, barn, бичок - ox, піп - Роре, шинок - tavern.

For the members of the original lingvocultural community such conceptual and semantic features are typical indicators of the certain situation, but in the foreign-language and under the foreign cultural conditions they do not have these pragmatic functions: the representatives of different linguocultural community do not have the necessary presuppositions for the exact identification of these signs functions because of their non-representation in the objective world and, respectively, in folklore and mythological context. As a result, these features can be regarded as "foreign", "alien", "unclear" and, being implied in the other lingucultural space, tend to take the peripheral place.

\section{Translating culturally marked vernacular vocabulary}

Folklore, in modern usage, an academic discipline the subject matter of which (also called folklore) comprises the sum total of traditionally derived and orally or imitatively transmitted literature, material culture, and custom of subcultures within predominantly literate and technologically advanced societies; comparable study among wholly or mainly nonliterate societies belongs to the disciplines of ethnology and anthropology. In popular usage, the term folklore is sometimes restricted to the oral literature tradition.

Folklore studies began in the early 19th century. The first folklorists concentrated exclusively upon rural peasants, preferably uneducated, and a few other groups relatively untouched by modern ways (e.g., gypsies). Their aim was to trace preserved archaic customs and beliefs to their 
remote origins in order to trace the mental history of mankind. In Germany, Jacob Grimm used folklore to illuminate Germanic religion of the Dark Ages. In Britain, Sir Edward Tylor, Andrew Lang, and others combined data from anthropology and folklore to "reconstruct" the beliefs and rituals of prehistoric man. The best-known work of this type is Sir James Frazer's The Golden Bough (1890).

As the scholarship of folklore developed, an important advance was the classification of material for comparative analysis. Standards of identification were devised, notably for ballads (by F.J. Child) and for the plots and component motifs of folktales and myths (by Antti Aarne and Stith Thompson). Using these, Finnish scholars, led by Kaarle Krohn, developed the "historical-geographical" method of research, in which every known variant of a particular tale, ballad, riddle, or other item was classified as to place and date of collection in order to study distribution patterns and reconstruct "original" forms. This method, more statistical and less speculative than that of the anthropological folklorists, dominated the field throughout the first half of the 20th century.

Large collections of material were amassed in the course of these efforts. Inspired by the Grimm Brothers, whose first collection of fairy tales appeared in 1812, scholars all over Europe began recording and publishing oral literature of many genres: fairy tales and other types of folktales, ballads and other songs, oral epics, folk plays, riddles, proverbs, etc. Similar work was undertaken for music, dance, and traditional arts and crafts; many archives and museums were founded. Often the underlying impulse was nationalistic; since the folklore of a group reinforced its sense of ethnic identity, it figured prominently in many struggles for political independence and national unity ${ }^{4}$.

While dealing with the culturally marked vernacular vocabulary in different languages I came across the translations of some Ukrainian folklore texts into English: "Cossack fairy tales and folk tales by Bain R. Nisbet" "Sixty folk - tales from exclusively Slavonic sources. Translated with brief introductory notes by A. H. Wratislaw", "Myths and folk-tales of the Russians, Western Slavs, and Magyars by Jeremiah Curtin”, "Russian folktales by W. R. S. Ralston” " “The songs of the Russian people, as illustrative

${ }^{4}$ Encyclopaedia Britannica Available online www.britannica.com.

${ }^{5}$ Bain R. N. Cossack fairy tales and folk tales 1902.

${ }^{6}$ Wratislaw A. H. Sixty folk-tales from exclusively Slavonic sources. Translated with brief introductory notes by A. H. Wratisla. London 1889.

${ }^{7}$ Curtin J. Myths and folk-tales of the Russians, Western Slavs, and Magyars by Jeremiah Curtin, Boston 1903.

${ }^{8}$ Ralston W. R. S. Russian folk-tales, London 1873. 
of Slavonic mythology and Russian social life", "Songs of Ukraina with Ruthenian poems translated by Florence Randal Livesay" 10 . Those texts were chosen as the material of the following research because of the high lingvocultural potential of the folk vocabulary they contain. Our main aim was to try show the background knowledge essence in translating the cultural fragments from one language into another.

In the preface to "Cossak Fairy tales and folk-tales selected edited and translated by R. Nissbet Bain" Ukrainian is identified as the language of Cossaks: "The favorable reception given to my volume of Russian Fairy Tales has encouraged me to follow it up with a sister volume of stories selected from another Slavonic dialect extraordinarily rich in folk-tales - I mean Ruthenian, the language of the Cossacks..." Feather the translator specifies "Ruthenian is a language intermediate between Russian and Polish, but quite independent of both" ${ }^{2}$. Such argumentation is the example of the complete misidentification of the Ukraine in general as the cultural surrounding as well as of its folklore, traditional to the European folklorists, as the translations from the Ukrainian where made through Russian. As we can see, the translators as the representatives of a certain national lingvocultural communities, not always have a cognitive framework that is structured in a certain way of other national-cultural community indispensable knowledge, and this linguocultural background, specific national cultural mentality is not recognized.

Now we are going to stop on some folk text cultural codes. Being the constituents of the folklore world picture they realize the cultural asymmetry. While studying the above translations we can assume that lacuna and culturally marked vocabulary mainly deals withwith everyday life, like food and beverage, meal hours, etiquette; with living conditions, such as: living conditions in the city and in the the countryside; living standards (regional, social and ethnic group variants), chores; etiquette and ritual behavior; abstract concepts inherited by a certain culture; traditions, customs, superstitions realized in the mythology.

\footnotetext{
${ }^{9}$ Ralston W. R. S. The songs of the Russian people, as illusteative of Slavonic mythology and Russian social life, Eontton 1872.

${ }^{10}$ Livesay R. F. Songs of Ukraina with Ruthenian poems translated by Florence Randal Livesay, London 1916.

${ }^{11}$ Bain R. N. Cossack fairy tales and folk tales 1902. P. 10.

12 Ibid. P. 12.
} 


\section{Everyday life, like food and beverage, meal hours, etiquette; chores}

The folk food and beverage names are not translated but transcribed into English. Though sometimes occur the cases of mistranslation due to the attempt of the translator to substitute the specific cultural fragments with the familiar to the target language users images. We've noticed rather funny fragments with the use of traditional Ukrainian foods and beverages. For example Traditional Ukrainian spirit горілка is rendered into English by means of the lexeme brandy.

Горілка (sometimes popularly used the word горівка) (from the burning taste) or оковита (lat. Aqua vita - the water of life, living water) a strong alcoholic drink from cleaned alcohol. Горілка is made from a solution of ethanol in water, usually - 40\% (by volume). Industrially produced from high-quality cereals under alcohol purification. Beyond Ukraine the word Горілка is used to name the Ukrainian bitter pepper drink. Горілка, made at home, is called самогон оr самогонка. The main raw material for the manufacture of самогон is sugar beet or beet sugar.

Brandy, is an alcoholic beverage distilled from wine or a fermented fruit mash. The term used alone generally refers to the grape product; brandies made from the wines or fermented mashes of other fruits are commonly identified by the specific fruit name. The name comes from the Dutch brandewijn ("burnt wine"), referring to the application of heat in distillation. Commercial distillation of brandy from wine originated in the 16th century. According to one story, a Dutch shipmaster began the practice by concentrating wine for shipment, intending to add water upon reaching home port, but the concentrated beverage immediately found acceptance $^{13}$. Ukrainian folklore heroes, more often ordinary peasants, never head of brandy, as a drink.

\section{Living conditions, such as: living conditions in the city and in the the countryside; living standards (regional, social and ethnic group variants)}

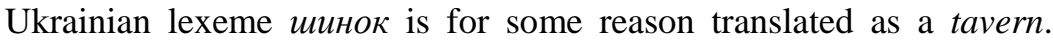
Though the nature of the words as well as their etymology is quite different. According to the Etymological Dictionary of the Ukrainian

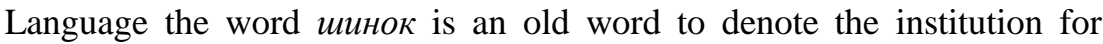
selling and drinking alcohol. The word is borrowed from Germain through Polish: g. Schenke «шинок», svl. schenk(e) «the sale of the strong drinks» connected with the word schenken «give; present wine in the korchma

\footnotetext{
${ }^{13}$ Encyclopaedia Britannica Available online www.britannica.com/
} 
(another Ukrainian name for a drinking place)», the word is close to the English skink «to pore (wine, bier)»; germ.*skankian «to hold awry» prodused from the adjective *skanka - «awry» ${ }^{14}$.

The English nomination tavern, is used to name the establishment where alcoholic beverages are sold for consumption on the premises. Tavern keeping has paralleled the growth of trade, travel, and industry throughout history and virtually worldwide (http://www.britannica.com/ topic/tavern). As to the etymology, the word tavern appeared in the late 13c., with the meaning of the "wine shop," later "public house" (mid-15c.), from Old French tavern (mid-13c.) "shed made of boards, booth, stall," also "tavern, inn," from Latin taberna "shop, inn, tavern," originally "hut, shed, rude dwelling," possibly by dissimilation from *traberna, from trabs (genitive trabis) "beam, timber," from PIE *treb"dwelling" (cognates: Lithuanian troba "a building," Old Welsh treb "house, dwelling," Welsh tref "a dwelling," Irish treb "residence," Old English ðorp "village, hamlet, farm, estate"). If so, the original meaning probably was "wooden shed"15.

\section{Traditions, customs, superstitions, mythology}

For example the Ukrainian $O x$ is transcribed as $O h$, Oh is an ancient Slavonic mythical creature, the ruler of the Forest Kingdom. Appears in the tale called "Oh" and is described as the short old man all green with a long beard. Appears out of nowhere on a stump after someone sitting on a tree stump exclaims the word "oh". In the English version of the tale $O x$ is described "as a little little old man, all so wrinkled and puckered, and his beard was quite green and reached right down to his knee”. In Ukrainian $O x$ is an exclamation used for the expression of physical pain, suffering, fear, a feeling of relief and so on. In English oh is an exclamation used to express a range of emotions including surprise, anger, disappointment, or joy, or when reacting to a remark. The target language notion is corresponding the source language word not only in the form but is very close to the base concept. But the Ukrainian word мавки is translated as water-nixies: “А за наймичок у Оха мавки - такі зелені, як рута!”. "And Oh had water-nixies for serving-maids, and they were all as green as rue." Мавка is Fairy forest creature in the image of a beautiful naked girl with long flowing hair, the closest British image is the wood nymph. The Neck, Nicor, or Nixie or Nokken (German: Nixe; Norwegian: nøkk;

${ }^{14}$ Етимологічний словник украӥнської мови в 7-ми томах Редкол. О. С. Мельничук (голов. ред.), Київ: Наукова думка 1982-1989. Т. 5, 345.

${ }^{15}$ Online Etymology Dictionary Available online: http://etymonline.com. 
Swedish: näck; Finnish:näkki) are shapeshifting water spirits in Germanic mythology and folklore, who usually appeared in forms of other creatures. Nixe from Old High German nihhus is a crocodile; related to Sanskrit nijanas "washing oneself". The male Nix (Nicker) was originally a watermonster of an animal nature, regarded as malicious and dangerous. In Sweden, it is known as Nack. The female Nixe is a water-sprite with a human torso and the tail of a fish. There are similar beings in the folklore of many nations: cf. the $\rightarrow$ Rusalka of the Slavs and the $\rightarrow$ Ningyo of the Japanese. So it is obvious that those spirits are of different nature ${ }^{16}$.

The word чopm is generally rendered by "demon" or "devil", yopm is considered to be a demon of total evil, with horns, hoofs, skinny tail, and a pig-face in Slavic mythology (demonology). He is the son of the Slavic god Chernobog and the goddess Mara. In Ukraine, he is also known as гаспид, дідько, ірод і куичий (haspyd, didko, irod, and kutsyi). In folk Christianity, he is considered a minion of Satan ${ }^{17}$.

As T. Peredriyenko observes "The feature of the nominations of the kind is that the Slavic lingvocultural name for the concept is the lexical unit yopm which is opposed to English, where the name standing for the concept is the nomination devil (Ukrainian диявол)"18. The devil is represented in church literature just as it was introduced in Slavic lingvocultures, that is devoid of national characteristics. The concept yopm has come about a very significant change: it has obtained new features, as well as managed to keep the old, absorbing the signs of the Satan and hell, pagan and Christian devil and Satan. In the modern lingvoculture the notion of чopm is used as genitive - to describe the ancient pre-Christian faith evil spirit and in the Christian sense, the image of the devil.

The direct naming of the Devil, as with the deity, has been subject to severe taboos originating in notions of word magic. There has always been respect for diabolical power and a belief that an oath invoking the Devil could be binding if heartfelt. Historically, however, the situation was more complex: the name of the Devil was very current in medieval oaths, then became euphemized, distorted, or "minced" between the Puritan and Victorian periods, and reinstated in the twentieth century. By this time, with the secularization of society, the name had little impact ${ }^{19}$.

${ }^{16}$ Online Etymology Dictionary. Available online: http://ety.monline.com.

${ }^{17}$ Войтович В. Украӥнська міфологія, Київ, 2005. С. 591.

18 Передриенко Т. Ю. Бог и дьявол Текст. Антология концептов. Т. З. Волгоград, 2006. C. 174.

${ }^{19}$ Hughes G. An encyclopedia of swearing : the social history of oaths, profanity, foul language, and ethnic slurs in the English-speaking world. Armonk: New York, 2006. P. 118. 
The English modern term devil derives from Anglo-Saxon deofol, which in turn is rooted in Greek $\delta 1 \alpha \beta 0 \lambda$ os, "the slanderer, liar or false accuser," the foundation of the notion of the Father of Lies. Although England was technically converted to Christianity in 597, Anglo-Saxon has many compounds, such as deofol craft for "witchcraft" or "devil worship," deofol seocnesse for "devil sickness" or "possession by the devil," and deofilisc, "devilish," all of which seemto be literal ${ }^{20}$.

Ukrainian Див is rendered into English by means of descriptive translation. The expression Evil Powers is used: In the olden times all manner of Evil Powers walked abroad. The translator also gives a note: Div. This ancient, untranslatable word (comp. Latin Deus)is probably of Lithuanian origin, and means any malefic power. In the Ukrainian mythology Див, Дій, Дів is first of all considered to be the God of the Sky. The ancestors usually gave the Sky the masculine image and the Land was associated with the feminine Goddesses. Див stands close to the main Slavic Gods, such as Perun, and mainly is not associated with the Evil Powers $^{21}$.

\section{Etiquette and ritual behavior}

The tradition of drinking as stereotyped behavior is one of the most common Ukrainian traditions described in the folk texts. Ukrainian expression випити на коня (to drink for the horse) is usually rendered into English as to have one for the road. In the Ukrainian correlate of this phraselogical unit we can see the updated and reinvented Cossack trip script. It refers to certain cultural stereotypes, etiquette-labeled behavior standards and, as a result, to rethinking of the original meal, drinking alcohol prototype. The origin of the English phrase to have one for the road is associated with the practice of passing death sentences. The sentenced to death was offered a last drink in the pub on the way to Tyburn Tree, the place public executions in London (http://www.backroadstouring.co.uk).

\section{Abstract concepts inherited by a certain culture}

Abstract concepts and ideas met in the Ukrainian folklore text prevail by the notions of soul (душа), happiness (щастя), fortune (доля) and so on. Ideas of the kind mainly inherit the mythologically specified images that cannot be translated in the word-to-word translation but demand the

\footnotetext{
${ }^{20}$ Hughes G. An encyclopedia of swearing : the social history of oaths, profanity, foul language, and ethnic slurs in the English-speaking world: Armonk, New York, 2006. P. 118.

${ }^{21}$ Войтович В. Українська міфологія: Київ, 2005. С. 146. 
essential knowledge of the Ukrainian specific mythology, culture as well as the folk psychology.

The peculiar feature of such concepts in Ukrainian and English is the partial difference of their semantic structure. English fortune is more abstract than Ukrainian щастя ог доля. In the English texts the word happiness mainly gives its name to the whole concept as a category: fortune acquired its meaning first in 1300, "chance, luck as a force in human affairs," from Old French fortune "lot, good fortune, misfortune" (12 c.), from Latin fortuna "chance, fate, good luck," from fors (genitive fortis) "chance, luck," possibly ultimately from PIE root*bher "to carry". If so, the sense might be "that which is brought". Sense of "owned wealth" is first found in Spenser; probably it evolved from senses of "one's condition or standing in life," hence "position as determined by wealth," then "wealth, large estate" itself. Often personified as a goddess; her wheel betokens vicissitude ${ }^{22}$.

Thus, we can say that the pursuit of happiness often met in folklore texts include, in its eessence, not only search for some abstract moral satisfaction, but also wealth. People views, specifications and superstitions concerning fortune have ethno-cultural specifications and original approach hat is differant from one civilization to another. This seme to some extent is implemented in the folklore texts. One can agree with S. G. Vorkachov who said that "the conceptual component of this concept is formed, above all, by the core definition that includes distinctive, genus-specific features that fix the boundaries of the domain to which it belongs: fortune is a positive and emotional evaluation of one's own fate. Another conceptual component formant of the fortune concept is presented by the essentialist semantics, which is associated with the interpretation of the last within a particular ideological concept. We can assume that the specific concept is precisely determined by the number of culturally marked everyday representations everyday concepts that are shared by the ethnic society members" ${ }^{23}$. So based on the following determination one can make a parallel between the English lexeme fortune, and the Ukrainian concept доля. The word доля is partially izosemic to fortune in the meaning of material wealth. According to the etymological dictionary of the Ukrainian language доля has the meaning "part; fate", and the lexemes бездолещь, бездолля, бездольний, бездольник, здольний, здольщина, знедолений, знедолити, недоля are its derivatives. The word comes from p. bl. доля, dr. доль, p. dola, ch. dola (from rus.), st. dole, slov. dol'a, дол(a) - psl. dolja "part”, connected with

\footnotetext{
${ }^{22}$ Online Etymology Dictionary. Available online .

${ }^{23}$ Воркачев С. Г. Кониепт счастья в русском языковом сознании: опыт лингвокультурологического анализа: Краснодар, 2002. С. 112.
} 
děliti "divide"; - related to lit. dalìs "part”, [dalià] "fortune, happyness", dalýti "divide"; the semantics ("part" > “доля") is close to the Russian yдел "part" - apanage; independent principality in mediaeval Russia, участь (lot, destiny) $)^{24}$.

\section{CONCLUSIONS}

It seems possible to conclude that the translation of the folk text concerning its style high frequency of outdated vocabulary and a large number of realities peculiar to a source folklore language also shows a difficulty of transferring the historical and cultural coloring. When translating it often occurs that some background cultural information, of a native speaker (source language speaker) does not correspond to the information contained in the target language. This information can turn into unfamiliar and incomprehensible, even if it deals with an ordinal, seemingly similar situation. Lacunae vocabulary, the words that can not be rendered with a simple translation, being the integral part of each of the lexical systems, depict the uniqueness of ethno-cultural group individual perception. Such vocabulary is mainly traced while dealing with everyday life, like food and beverage, meal hours, etiquette; with living conditions, such as: living conditions in the city and in the the countryside; living standards (regional, social and ethnic group variants), chores; etiquette and ritual behavior; abstract concepts inherited by a certain culture; traditions, customs, superstitions realized in the mythology. Thus the problem of rendering culturally marked lexicon in the folk text depends on the level of the translator's background knowledge. The gaps in which bring the partial or complete misunderstanding of the source text can as well lead to the full misidentification of the source language culture.

\section{SUMMARY}

The paper deals with the translation of units that belong to the folk vocabulary in Ukrainian, English taking into account specific lingvocultural features inherent in each language. The patterns of structural and semantic organization of the main translational models of such vocabulary are settled. The means of verbalization and cultural coding within "folk" world picture are traced. The conceptual basis of the linguocultural semantics objectification of folk vocabulary in Ukrainian, English texts of the XIX century are studied. Lacunae (culturally marked lexical units) are considered as the main difficulty for rendering from one

\footnotetext{
${ }^{24}$ Етимологічний словник украӥнської мови в 7-ми томах Редкол. О. С. Мельничук (голов. ред.). Київ: Наукова думка, 1982-1989. Т. 2. 107.
} 
language into another. The specific ways of such culturally marked lexical units translation are reviewed through figurative categories used in folk vocabulary (metaphor, simile, connotation). The special attention is paid to rendering the mithological lexical and phraseological units that are singled out as a separate layer of folk vocabulary, as well as the precedent phenomena impact on the appearance of precedent names. The main task of this research is to select, describe and study the folk lacunae vocabulary of the three languages in accordance to each other (based on the texts of the XIX century), to determine the means of lacunae compensation in the dictionaries as well the folk texts of the XIX centuries translated. The cause of lacunae one language units appearance in relation to the other languages and vice a versa is determined, the selection of ethnographic lacunae units are compared with other languages, as well as the development of equivalence and adequacy conditions of translation at the level of lacunae units of compared languages is studied.

\section{REFERENCES}

1. Войтович В. Українська міфологія. Київ 2005.

2. Воркачев С. Г. Конщепт счастья в русском языковом сознании: опыт лингвокультурологического анализа. Краснодар 2002.

3. Етимологічний словник украӥнської мови в 7-ми томах. Редкол.

О. С. Мельничук (голов. ред.). Київ: Наукова думка 1982-1989.

4. Передриенко Т. Ю. Бог и дьявол Текст. Антология конщептов. Т. 3. Волгоград, 2006.

5. Сорокин Ю. А. Переводоведение: статус переводчика и психогерменевтические прочедуры. Москва, 2003.

6. Bain R. N. Cossack fairy tales and folk tales 1902.

7. Collins English Dictionary. Available online: http://www.collinsdictionary.com/dictionary/english.

8. Curtin J. Myths and folk-tales of the Russians, Western Slavs, and Magyars by Jeremiah Curtin. Boston, 1903.

9. Encyclopaedia Britannica. Available online www.britannica.com.

10. Hughes G. An encyclopedia of swearing : the social history of oaths, profanity, foul language, and ethnic slurs in the English-speaking world. Armonk, New York, 2006.

11.Livesay R. F. Songs of Ukraina with Ruthenian poems translated by Florence Randal Livesay. London, 1916.

12. McCormick Ch., White K. Folklore. An Encyclopedia of Beliefs, Customs, Tales, Music, and Art. ABC-CLIO, 2010.

13. Online Etymology Dictionary. Available online http://etymonline.com.

14. Ralston W. R. S. Russian folk-tales. London, 1873. 
15. Ralston W. R. S. The songs of the Russian people, as illusteative of Slavonic mythology and Russian social life. Eontton, 1872.

16. Wratislaw A. H. Sixty folk-tales from exclusively Slavonic sources. Translated with brief introductory notes by A. H. Wratisla. London, 1889.

\section{Information about the author:}

Palchevska O. S.,

Ph.D., Associate Professor at the Department of Foreign Languages and Translation Studies,

Lviv State University of Life Safety 35, Kleparivska str., Lviv, 79007, Ukraine 


\section{CONCEPTUAL EQUIVALENCE AS A CRITERION OF TRANSLATION QUALITY ASSESSMENT}

\section{Popovych N. M.}

\section{INTRODUCTION}

This study is based on the recent contributions in the fields of translation studies and mostly translation criticism, corpus linguistics with its corpus-based language research and collecting of different statistic data on language use and variety, conceptual semantics that roots mostly on R. Jackendoff's theory of lexical concepts and other relevant to its subjectmatter fields.

J. Naudé provides six assumptions for the translation of religious texts, i.e., (1) translation of religious texts as normal translation, (2) translation of sacred texts as opening up of a foreign culture, (3) translations of sacred texts for specific purposes, (4) utilising translation strategies instead of striving towards equivalence, (5) a descriptive instead of a normative analysis of the translations of sacred texts and (6) cultural knowledge in the translation of sacred texts is shaped by the epistemology, hermeneutics and religious spirituality of the translators ${ }^{1}$. Hence, according to these assumptions the right principles of religious text translation do not still exist and the religious text translatability is very difficult to reach.

Many Ukrainian, Western European and American scholars contributed to the development of the theory of equivalence and translatability.

O. O. Potebnya suggested the preservation of the unity of the external form, content and internal form of the source text in the target language text, V. N. Komissarov developed the hierarchical model of equivalence, A.D. Shveitser suggested the layered model of communicative and pragmatic equivalence, Ya. Y. Retzker in 1974 elaborated the theory of regular correspondences (equivalence within the text units). E. Nida, J. Catford, H. Hönig, M. Snell-Hornby, G. Jäger, use the notion of "equivalence" as a key term for Western European and American translation studies scientific schools. Western European scholars differentiate full equivalence and relative equivalence. Supporters of the first tendency were E. Naida, J. Ketford, G. Hönig, P. Kussmaul, K. Rice,

${ }^{1}$ J. Naudé, Religious translation / J. Naudé // Handbook of Translation Studies,ed. Yves Gambier and Luc van Doorslaer. Amsterdam/Philadelphia: John Benjamins Publishing Company. Vol. 1. 2010. 458 p. P. 285-292. 
G. Fermeer, M. Snell-Hornby. Jäger, V. Koller, J. Albrecht, and G. Gertzimisch-Arbogas supported the second type of equivalence. In 1965, J. Catford suggested formal and text-level equivalence.

E.Nida preferred the term "functional equivalence".What the term "functional equivalence" suggests is not just that the equivalence is between the function of the source text in the source culture and the function of the target text (translation) in the target culture, but that "function" can be thought of as a property of the text. It is possible to associate functional equivalence with how people interact in cultures ${ }^{2}$.

Correspondence of the source language unit to the target language unit on the level of their conceptual sememe component correspondence which are characterized by image, perceptual and value connotations ${ }^{3}$.

Translated and Ukrainian religious concepts and religious terminology were studied in various aspects by G. Baran, S. Bibla, S. Bogdan, O. Biletsky, S. Bilyk, T. Vilchynska, L. Voronovskaya, S. Garbuz, I. Grimalovsky, Ya. Dzoganik, G. Didyk-Meush, U. Doboshevych, E. Zhernovy, V. Zadorozhny, L. Zakrenitska, O. Ivashchenko, Z. Kasprishin, M. Kolbuch, Z. Kunch, G. Kuz, O. Kurganova, I. Lopushinsky, T. Markotenko, O. Matushek, G. Nakonechna, V. Nimchuk, Hilarion (Ohienko), M. Petrovich, N. Poddubna, L. Polyuga, M. Priymich, O. Pryskoka, N. Puryaev, M. V. Skab, K. Simovich, Y. Chernyshova, M. Fabian, L. Fedash, P. Chuchka, I. Shevchenko, M. Shtets, A. Yasinovskyi and O. Yasinovskyi.

Corpus linguistics is relevant to the study of translatability and translation equivalence theories, conceptual equivalence and verbalized concepts in the target language text by means of different corpus-based tools. FrameNet is one which gives the possibility to closer study of the verbalized target language concepts and their componential meanings and "is based on a theory of meaning called Frame Semantics, deriving from the work of Charles J. Fillmore and colleagues (Fillmore 1976, 1977, 1982, 1985, Fillmore and Baker 2001, 2010). The basic idea is straightforward: that the meanings of most words can best be understood on the basis of a semantic frame, a description of a type of event, relation, or entity and the participants in it" ${ }^{\text {. }}$.

\footnotetext{
${ }^{2}$ Nida, Eugene A., Charles R. Taber. (1969). The Theory and Practice of Translation, With Special Reference to Bible Translating, 200. Leiden: Brill. P. 51.

3 Попович Н.M. Давньогрецька тринітарна термінологія у різномовних перекладах (На матеріалі патристичної літератури IV століття): монографія / науковий редактор проф. Клименко Н.Ф. Ужгород: Видавництво УжНУ «Говерла», 2018. 309 с. С. 43-50.

${ }^{4}$ What is FrameNet? [Online]. Available: https://framenet.icsi.berkeley.edu/fndrupal/ WhatIsFrameNet.
} 


\section{Main issues of religious text translatability}

It is known that the problem of translatability has existed since the time the practice of translation existed itself. There were attempts to theoretically substantiate and address the problems of translatability by contemporaries and even precursors of the Fathers of the Church. Such was the experience of the famous translator Saint Jerome of Stridon. In addition to the translation of the Gospel into Latin, i.e., the Vulgate, the writer and translator raised the issues of translatability, recognizing the difficulties of translating "the Chronicles" of Eusebius into Latin.

N. Kholmohorova, the translator of St. Jerome's "Letter LVII. To Pammachius on the Best Method of Translating” into Russian ${ }^{5}$, underlines that the voices of the Church Fathers remained unheard in today's discussions on the principles of biblical translation. Although main translation issues and difficulties discussed by Church Fathers remain very similar and close to nowadays' translation issues in the field of religious translation, they have not been completely resolved yet.

The absence of one text of the Holy Bible in Ancient Greek and Latin recognized by all Christian Churches, different ways of translating biblical texts suggested by the Ancient Greek philologists who had been developing the principles and the rules of translating for centuries, the importance of adequate biblical translations and its adaptability for every unusual doctrine are only a few issues the translators of the 4th century had to face and resolve. To gain the adequate translation of religious text today's translator faces the same difficulties and has to overcome similar obstacles to prove that the notion of translatability is more developed and the principles of translatability are fixed.

J. Naudé tends to divide the developmental history of Bible translation into four Great Ages. " The First Great Age (about 200 BCE to the fourth century CE) has a Jewish setting (Alexandria and Western Asia) and the target languages involved were Greek (Septuagint) and Aramaic (Targums \& Peshitta). The Second Great Age (fourth century CD to about 1500 or the Middle/Dark Ages) was Catholic in origin with its main centers in Palestine and the emerging Christian communities in the Roman Empire. The target language was Latin (Jerome's Vulgate). A salient feature of this age is the Christianising of the Hebrew source text; thus new meaning and nuances were read into Hebrew and Greek-Septuagint words and phrases. The Third Great Age (about 1500-1960) has an essentially Protestant setting.

\footnotetext{
${ }^{5}$ Иероним Стридонский. Письмо LVII. К Паммахию о наилучшем способе перевода / Иероним Стридонский; [пер. с латыни Н. Холмогоровой, под редакцией М. Касьян и Т. Миллер] // Альфа и Омега. № 4(7). 1995. С. 173-187.
} 
The target languages were English, German, French, Dutch, Spanish, etc. The main centers of activity were located in those regions where the (essentially Protestant) trade communities were developing at the expense of the old (essentially Catholic) feudalist establishments. ... The Fourth Great Age/Epoch/Phase in Bible translation introduces a significant change in the overall philosophy of Bible translation. It shows the unprecedented attempt on the part of the Jewish, Catholic, and Protestant communities in the United States and Great Britain to cooperate interconfessionally".

Translatability and translation assessment criteria (TAC) have been raised for discussion by many generations of translators until now. As it was already stated in many scientific contributions to translatability issues, text translating as a process undergoes multilayered transformations until it is recreated in the socio-cultural tradition of the target language. To compare the stylistic and lexico-grammatical features of the text translated into the target language, to assess its quality and see better and more faithful equivalents for specific terminology etc. are the tasks of translator himself or his colleagues, i.e. translation critics.

Multicultural differences, language similarity and dissimilarity, source and target texts time distance, individual and very particular author's picture of the world, verbalized concepts of the source language text are those obstacles, to name just few, translator has to overcome to make the target text adequate, faithful and accessible to the target reader or listener.

The highest possible level of translatability can be defined by E. Nida and C.R.Taber (1974) thesis. They "view translation as reproducing in the receptor language the closest natural equivalent of the source text, first in terms of meaning and secondly in terms of style. A translation is dynamic equivalent to the source text if the message of the source text has been transported into the receptor language in such a way that the response of the receptor is essentially that of the original receptors" ${ }^{\text {" }}$.

\section{The Idea of Corpus-Based Concept Analysis of the Target Religious Texts}

Corpus-based language study increased tremendously during the last two decades. Corpus tools are applied in language acquisition techniques, support indispensably translation or interpreting activities and are of great

${ }^{6}$ J. Naudé, Religious translation / J. Naudé // Handbook of Translation Studies,ed. Yves Gambier and Luc van Doorslaer. Amsterdam/Philadelphia: John Benjamins Publishing Company. Vol. 1. 2010. 458 p. P. 288-289.

${ }^{7}$ 1. Naudé J., Religious translation / J. Naudé // Handbook of Translation Studies,ed. Yves Gambier and Luc van Doorslaer. Amsterdam/Philadelphia: John Benjamins Publishing Company. Vol. 1. 2010. 458 p. P. 289.. 
importance for specific linguistic research purposes. Corpus tools aimed at completing different linguistic tasks can be classified into groups in accordance with the needs of the final user. Some recent classifications of corpus tools and corpus toolboxes has outlined the discrepancy between real functional and desirable multifunctional adaptability of corpus tools in resolving the above mentioned tasks.

The notion "linguistic corpus" means "electronically available collection of texts or transcripts of audio recordings which is sampled to represent certain language, language variety or other linguistic domain" ${ }^{\text {. }}$ Although optionally, text corpora and corpus tools comprise the levels of linguistic analysis called linguistic annotation ${ }^{9}$. The data collected into corpus "can vary tremendously in quality and quantity depending on the research design" "Previously proposed classifications of corpora and corpus tools were aimed at developing the tool which, within the bulk of mainstream corpus tools available nowadays, would be of task-based functionality or multifunctionality and would extract that kind of information from the text data the researcher needs for the ongoing investigation" "10. Hence, it was suggested to classify corpora and corpus tools into groups for better understanding of their advantages and disadvantages and for putting forward the solutions of the underlying problems. We divide corpus tools and corpora into four major groups: (1) content-based, (2) functionality-based, (3) aim- or purpose-based and (4) generation-based corpora and corpus tools. There is also a great number of different linguistic tools, i.e., so-called corpus software tools directed toward the accomplishment of one task either linguistic or statistic in its nature. Among them are offline and web-based concordancers like AntConc (v.3.5.8, February 18, 2019), WordSmith Tools (v. 7, 2019), \#LancsBox (v 4.0, 2018), JConcorder (ver. 1.beta.13, 2011), text coding, (manual) annotation programs, text-analysis tools \& search engines like DART (ver. 3.0, 2019), Dexter and tools \& resources for transcribing, annotating or analyzing texts (inc. speech or audio-visual) like CLaRK, ELAN (EUDICO Linguistic Annotator), GATE (General Architecture for Text Engineering), stats tools like Log-likelihood and effect size calculator, taggers like CLAWS, Stanford POS tagger and others ${ }^{11}$.

${ }^{8}$ S. Kübler and H. Zinsmeister, Corpus Linguistics and Linguistically Annotated Corpora (Engli.sch), New York; London: Bloomsbury Academic, 2015. P. 21-156. http://dx.doi.org/ 10.5040/9781472593573.

${ }^{9}$ Ibid.

${ }^{10}$ A. Lutskiv, N. Popovych. (8-11/10.2019). Adaptable Text Corpus Development for Specific Linguistic Research in Proc. of 2019 IEEE International Scientific and Practical Conference "Problems of Infocommunications. Science and Technology".

${ }^{11}$ Ibid. 
Content-based corpora and corpus tools can be subdivided into 1.1. national, 1.2. professional, 1.3. parallel, 1.4. comparable, 1.5. specialized and 1.6. task-based (adaptable or mixed). The examples of English corpora are vastly overrepresented and described in a number of English corpus reviews, but to be named English national corpora or pretending to be of standard English, there are only a few of them worth mentioning. The Brown Corpus of Standard American English or the Brown Corpus by W.N. Francis and H. Kucera, the British National Corpus managed by the BNC Consortium and the Corpus of Contemporary American English are the most vivid examples of national corpora of both British and American English. Firstly, they all are monolingual, i.e., representing modern British English or American English, but not other languages written or spoken in those countries. Secondly, they are synchronic and general, i.e., including many different styles and varieties, and are not limited to any particular subject field, genre or register and containing examples of both spoken and written language. And finally, both the British National Corpus and the Brown Corpus are sample corpora that allow for a wider coverage of texts within certain limit.

Ukrainian National Corpora are represented by several projects which have been realized till nowadays. Corpus of the Ukrainian Language (N. Dartchuk, O. Siruk, M. Langenbach, Ya. Khodakivska, V. Sorokin at the Institute of Philology of TKU of Kyiv), Laboratory of Ukrainian (Ukrainian) and General Regionally Annotated Corpus of Ukrainian (GRAC) (Ukrainian), to name just a few which are the most developed of the Ukrainian language corpora and corpus tools. The latter are not the same in terms of quality and effectiveness in comparison to those developed for the English language analysis and for English user. English corpora and corpus tools have larger range of choice and are of different content, purpose and functional capacity.

Professional corpora and corpus tools are more content-oriented and focused on specialist language and vocabulary like Air Traffic Control (ATC) Corpus or Carnegie Mellon Communicator Corpus.

OPUS is one of the best examples of parallel multilingual corpora which contains converted and aligned free online data and added linguistic annotation. OPUS project team provides the community with a publicly available parallel corpus. It is based on open source products and the corpus is also delivered as an open content package.

Another type of multilingual corpus is comparable corpus which consists of original texts rather than translations where all texts are similar in content, but they differ in languages or language varieties in the sense that the texts of the same domain are aligned. These types of corpora are 
aimed at comparing the languages or varieties presented in similar circumstances of communication, without the distortions which appear in translated texts of parallel corpora.

To specialized corpora belong BASE (British Academic Spoken English) compiled by Hilary Nesi and Paul Thompson, BAWE (British Academic Written English), LANCAWE (Lancaster Corpus of Academic Written English) to name just a few.

All above named corpus groups can be also classified according to their functional annotation set into linguistic on the word level, syntactic, semantic and discourse. According to their aim or purpose corpora or corpus tools are divided into corpora for linguistic research and statistical data extraction. Language learner's corpus is highly demandable in the L2 acquisition process. Parallel and comparable corpora and other corpus tools are used in translation. The last type among aim-based corpora we identified is for lexicographical language study ${ }^{12}$.

Corpus-based concept analysis as a type of linguistic research is one of the newest trend in the corpus linguistics language analysis. The FrameNet project is one of the most relevant tool which could be used for corpusbased concept analysis. It has been in operation at the International Computer Science Institute in Berkeley since 1997 and presents a lexical database of English that is both human- and machine-readable, based on annotating examples of how words are used in actual texts ${ }^{13}$.

Corpus-based conceptual seme analysis of verbalized religious concepts would facilitate the interrelations on the level of conceptual seme equivalence study. FrameNet project, although it can satisfy more than 13,000 word senses, which are with annotated examples that show the meaning and usage and serve as a valence dictionary, with uniquely detailed evidence for the combinatorial properties of a core set of multilingual vocabulary, it is still cannot provide conceptual seme analysis using parallel corpora as a source and extract the minimal seme meaning of the verbalized concept. This idea found its realization in the mutual interdisciplinary project dedicated to the adaptable corpus development aimed at fulfillment of specific linguistic research. The software tool comprises the quality, effectiveness, option-based functionality and is taskbased or adaptable to specific linguistic research tasks with higher level of big data workflow capacity and less ambiguity indicator. Data analysis process is expected to allow the automation process of finding:

${ }^{12}$ Lutskiv A., Popovych N. (8-11/10.2019). Adaptable Text Corpus Development for Specific Linguistic Research in Proc. of 2019 IEEE International Scientific and Practical Conference "Problems of Infocommunications. Science and Technology".

${ }^{13}$ About FrameNet. [Online]. Available: https://framenet.icsi.berkeley.edu/fndrupal/about. 
1) generate - terms relevant to concepts; 2) synonyms; 3) polysems; 4) terms which are close by their meanings; 5) documents which are close by their meaning; 6 ) the most important terms in the documents.

An initial successful step in this direction has been taken on the example of the Holy Bible English translations with the analysis of more then1140 texts and shown the relations between concepts (such as light, road, life, heaven, temple etc.), documents and terms ${ }^{14}$.

\section{Classification of religious text information and the notion of conceptual equivalence}

\section{(On the Example of the Ancient Greek Religious Concept “Light”)}

The hypothesis of this study is based on the assumption that the information contained in the specialist' texts of the Ukrainian language is divided into three genera: 1 . The first-class information - conceptual, based on a conceptual schema or semantic network of interrelated concepts and concepts of a particular field of knowledge ${ }^{15}$; “ 2 . The second-class information - objectively logical and objective information in the author's vision of the surrounding world; 3. information of the third class subjective information: evaluative, emotional information, i.e., feelings, emotions, mood of the author" 16 .

The percentage of all three types of information in the texts of the seven styles of the Ukrainian literary language is different. Not all types of information are present in the individual style texts. For example, for the most part, scientific and technical texts do not contain the third kind of information, since they are devoid of the emotions, feelings and moods of the author.

On the example of the verbalized Ancient Greek religious concept "light" we are going to demonstrate the dependency of the content of the text on the sense power of the verbalized concept and the specificity of conceptual componential analysis of the verbalized conceptual sememe.

The concept of light is one of the most popular verbal icons of many cultures, religions and national traditions. There was suggested a twofold perspective of the concept development and its inner sense changeability by means of componential concept seme analysis. The continuity of one

${ }^{14}$ Lutskiv A., Popovych N. (8-11/10.2019). Adaptable Text Corpus Development for Specific Linguistic Research in Proc. of 2019 IEEE International Scientific and Practical Conference "Problems of Infocommunications. Science and Technology".

${ }^{15}$ Дэвидсон Д. Об идее концептуальной схемы / Д. Дэвидсон // Аналитическая философия. Избранные тексты [Сост. А.Ф.Грязнов]. - М.: Изд-во МГУ. - 1986 - С. 144-159.

${ }^{16}$ Некряч Т. Є. Через терни до зірок : труднощі перекладу художніх творів. Для студентів перекладацьких факультетів вищих навчальних закладів : навчальний посібник / Т. Є. Некряч, Ю. П. Чала. - Вінниця: Нова Книга, 2010. - 195 с.

96 
and the same verbalization of different and even polar concepts is also held as a fact not needed to be proved. The multilingual text passages rich in verbal representation of concept "light" and descending from different religious traditions and periods were examined for the quantitative results of the research.

M. Arranz, F. E. Brightman, F. J. Dölger, P. H. Engberding, John R. K. Fenwick, F.-N. Klein, V. Vojtovych, Metropolinat Ilarion (Ohiyenko) treated the concept of light from the viewpoints of religions' history and Christian liturgical traditions. Many investigators studied the verbalized concept of light from the linguistic point of view. The interdisciplinary study of such concepts is revealed to be an effective approach that helps to make apparent the continuity of the outer form (verbalized concept) through changeability and variations of the inner form (key ideas of different religions represented by one and the same verbalized concept). Hence, the verbalized concept outer form continuity through changeability of inner senses under the influence of different religious beliefs and traditions proved the fact of conceptual componential analysis necessity for the icons, notions and terms stylistically marked and concept dependent. In particular, the excerpts from ancient Hebraic berakhot, archaic classical and neo-hellenistic anaphoras, original and translated works of st. Basil the Great, prayers and liturgical rite of Eastern Christian tradition of Ukraine proved the fact of continuity through changeability of inner senses under the influence of different religious beliefs and traditions.

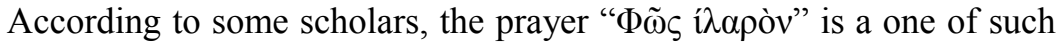
vivid examples of an interrupted verbalized concept existence. It takes its use in Hebraic berakha (thanksgiving to the evening light) through different prayer text forms to a magnificent prayer and chant completed by st. Basil the Great. Preserved in the Ukrainian Christian traditions of the Eastern rite this prayer reveals the live verbalized presence of Hebraic and Christian traditions till nowadays Although st. Basil transformed the key idea of the prayer and the concept of light is present in the prayer text as a simile to compare Light with one God in Trinity, a Hebraic verbalized idea of thanksgiving to the evening light is conserved at the very beginning of the prayer text:

The methodological foundations in the history of the translatability and the factors that determine the translatability dynamism require clarification of important translation concepts such as faithfulness, equivalence and adequacy. The ideas of the faithfulness, equivalence and adequacy in translation is based on the correlation of criteria and requirements that have been put forward by the scientist. The main objective to pursue was to find an approach that would preserve the integrity of the external form 
(lexico-grammatical word form), content (lexical meaning), and internal form (sense or conceptual meaning) of the original in translation"17.

One approach is to trace back the translating traditions which had been created for centuries. It is worth mentioning that in translating verbalized Ancient Greek concepts like " $\varphi \tilde{\omega} \varsigma$ " two translation traditions of the Ancient Greek Patristic texts should be taken into consideration. These two translating traditions made apparent through aspect comparative translation studies analysis. One tradition, so-called "Latin tradition", is the translation from Greek by the mediation of Latin translations. This translation influence is traced in the German, English and Italian translations of the Ancient Greek Patristic texts and concepts.

The second translating tradition, so-called "Slavonic tradition", is the translation from Greek by the mediation of the Ancient Bulgarian language. The second tradition is present in the Russian and Ukrainian translations of the Greek Patristic texts. The dependence on these traditions of the modern translations of the Ancient Greek Patristic texts is easy to trace in Trinitarian terminology translations and verbalized Trinitarian concepts. The source and target texts of the famous Prayer $\Phi \tilde{\omega} \zeta$ i $\lambda \alpha \rho$ òv, which are given below, demonstrate many cases of inadequacy in translating verbalized concept. Word-for-word, sense-to-sense, author's interpretation are the examples of possible concept translation into the target language. Concept "light” has several conceptual semes preserved in the target language texts, i.e., (1) the Divine Light (God's Nature), (2) the ineffable light, and the vision of the holy and sovereign Trinity, (3) onlybegottenly from the unbegotten light, (4) His uncreated light etc.

Table 1

\begin{tabular}{|c|c|c|}
\hline \multicolumn{3}{|r|}{ Original and Translations of the Prayer $\Phi \tilde{\omega} \varsigma$ i $i \lambda \alpha \rho \grave{v} v$} \\
\hline- & 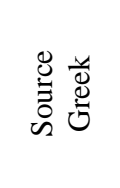 & 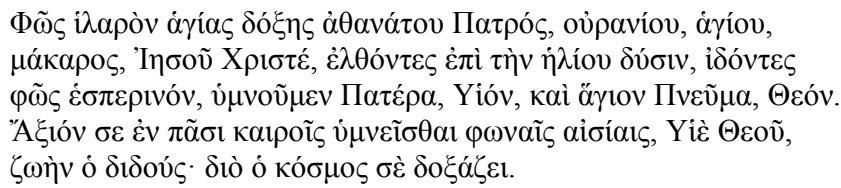 \\
\hline v & 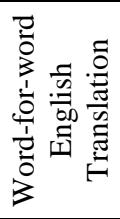 & $\begin{array}{l}\text { O Light gladsome of the holy glory of the Immortal Father, the } \\
\text { Heavenly, the Holy, the Blessed, O Jesus Christ, having come } \\
\text { upon the setting of the sun, having seen the light of the evening, } \\
\text { we praise the Father, the Son, and the Holy Spirit: God. Worthy it } \\
\text { is at all times to praise Thee in joyful voices, O Son of God, Giver } \\
\text { of Life, for which the world glorifies Thee. }\end{array}$ \\
\hline
\end{tabular}

17 Коптілов В. В. Теорія і практика перекладу. Навчальний посібник / Віктор Вікторович Коптілов.- К. : Юніверс, 2003. - 280 с. - С. 9-10. 
Table 1 (continuance)

\begin{tabular}{|c|c|l|}
\hline & $\begin{array}{l}\text { Вечірня пісня Синові Божому } \\
\text { Світе тихий святия слави безсмертнаго Отца небесного, } \\
\text { святаго, блаженнаго, Ісусе Христе! Пришедше на запад } \\
\text { солнца, видівше світ вечерній, поєм Отца, Сина і Святаго } \\
\text { Духа, Бога. Достоїн єси во вся времена піт бити гласи } \\
\text { преподобними. Сине Божий, живот даяй: тім же мір Тя } \\
\text { славит } 18\end{array}$ \\
\hline 18.
\end{tabular}

${ }^{18}$ Вечірня пісня Синові Божому/Молитви богослужбові з вечірні. [Online]. Available: https://parafia.org.ua/biblioteka/molytvy/pravoslavnyj-molytoslov/molytvy-bohosluzhbovi-zvechirni.

${ }^{19}$ The Unabbreviated Horologion, Jordanville, New York: Holy Trinity Monastery (published 1997), 1992, pp. 192-193. 
Table 1 (continuance)

\begin{tabular}{|c|c|c|}
\hline$\sigma^{\circ}$ & 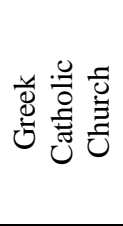 & $\begin{array}{l}\text { O Joyful Light of the holy glory of the Father Immortal, the } \\
\text { heavenly, holy, blessed One, O Jesus Christ, now that we have } \\
\text { reached the setting of the sun, and see the evening light, we sing } \\
\text { to God, Father, Son, and Holy Spirit (+). It is fitting at all times to } \\
\text { raise a song of praise in measured melody to you, O Son of God, } \\
\text { the Giver of Life. Therefore, the universe sings your glory. }{ }^{20} \text {. }\end{array}$ \\
\hline$\stackrel{0}{-1}$ & 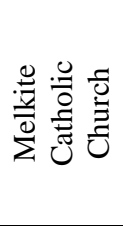 & $\begin{array}{l}\text { Oh, Joyful Light, of the Holy Glory of the Father Immortal. } \\
\text { Heavenly, Holy, Blessed, Jesus Christ, since we have come, to the } \\
\text { setting of the sun, and have seen the evening light, we praise God: } \\
\text { the Father, the Son, and the Holy Spirit (+). It is proper for you to } \\
\text { be praised at all times by fitting melody. Oh, Son of God, Giver of } \\
\text { Life, wherefore the world glorifies You. }\end{array}$ \\
\hline$\dot{\beth}$ & 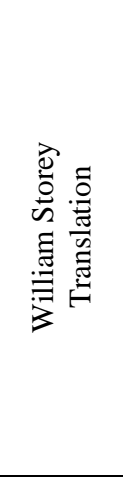 & $\begin{array}{l}\text { Used in the Office of the Dead and at Evening Prayer. } \\
\text { O radiant light, O sun divine } \\
\text { Of God the Father's deathless face, } \\
\text { O image of the light sublime } \\
\text { That fills the heav'nly dwelling place. } \\
\text { O Son of God, the source of life, } \\
\text { Praise is your due by night and day; } \\
\text { Our happy lips must raise the strain } \\
\text { Of your esteemed and splendid name. } \\
\text { Lord Jesus Christ, as daylight fades, } \\
\text { As shine the lights of eventide, } \\
\text { We praise the Father with the Son, } \\
\text { The Spirit blest and with them one. }\end{array}$ \\
\hline$\underset{\sim}{\sim}$ & 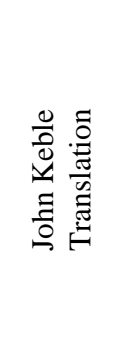 & $\begin{array}{l}\text { Hail, gladdening Light, of His pure glory poured } \\
\text { Who is the immortal Father, heavenly, blest, } \\
\text { Holiest of Holies, Jesus Christ our Lord! } \\
\text { Now we are come to the sun's hour of rest; } \\
\text { The lights of evening round us shine; } \\
\text { We hymn the Father, Son, and Holy Spirit divine! } \\
\text { Worthiest art Thou at all times to be sung } \\
\text { With undefiled tongue, } \\
\text { Son of our God, Giver of life, alone: } \\
\text { Therefore in all the world Thy glories, Lord, they own }{ }^{21} \text {. }\end{array}$ \\
\hline
\end{tabular}

20 "MCI - Publications of the Byzantine Catholic Church".[Online]. Available: metropolitancantorinstitute.org.

${ }^{21}$ Anglican Hymn Book \#54 /translated by John Keble// Church Book Room Press - 1965. [Online]. Available:. https://hymnary.org/text/hail_gladdening_light_of_his_pure_glory_ 
Table 1 (continuance)

\begin{tabular}{|c|c|c|}
\hline$\dot{\sim}$ &  & $\begin{array}{l}\text { O gladsome light, O grace Of God the Father's face, } \\
\text { The eternal splendour wearing; Celestial, holy, blest, } \\
\text { Our Saviour Jesus Christ, Joyful in thine appearing. } \\
\text { Now, ere day fadeth quite, We see the evening light, } \\
\text { Our wonted hymn outpouring; Father of might unknown, } \\
\text { Thee, his incarnate Son, And Holy Spirit adoring. } \\
\text { To thee of right belongs All praise of holy songs, } \\
\text { O Son of God, Lifegiver; Thee, therefore, O Most High, } \\
\text { The world doth glorify, And shall exalt forever. }\end{array}$ \\
\hline$\dot{ \pm}$ & 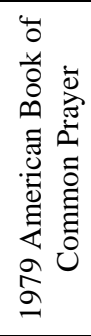 & $\begin{array}{l}\text { O gracious Light, } \\
\text { pure brightness of the everliving Father in heaven, } \\
\text { O Jesus Christ, holy and blessed! } \\
\text { Now as we come to the setting of the sun, } \\
\text { and our eyes behold the vesper light, } \\
\text { we sing your praises, O God: Father, Son, and Holy Spirit. } \\
\text { You are worthy at all times to be praised by happy voices, } \\
\text { O Son of God, O Giver of life, } \\
\text { and to be glorified through all the worlds. }\end{array}$ \\
\hline ம் & 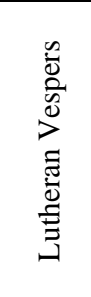 & $\begin{array}{l}\text { Joyous light of glory of the immortal Father, } \\
\text { Heavenly, holy, blessed Jesus Christ, } \\
\text { We have come to the setting of the Sun } \\
\text { And we look to the evening light. } \\
\text { We sing to God, the Father, Son and Holy Spirit. } \\
\text { You are worthy of being praised with pure voices forever. } \\
\text { O Son of God, O Giver of life, } \\
\text { The universe proclaims your glory. }\end{array}$ \\
\hline$\dot{\varphi}$ & 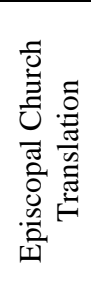 & $\begin{array}{l}\text { Light of the world in grace and beauty, } \\
\text { mirror of God's eternal face, } \\
\text { transparent flame of love's free duty, } \\
\text { you bring salvation to our race. } \\
\text { Now, as we see the lights of evening, } \\
\text { we raise our voice in hymns of praise; } \\
\text { worthy are you of endless blessing, } \\
\text { Sun of our night, Lamp of our days. }\end{array}$ \\
\hline
\end{tabular}

\section{CONCLUSIONS}

The theoretical basis of this study presents the conceptual scheme of D. Davidson, framenets and conceptual analysis based on Frame Semantics, deriving from the work of Charles J. Fillmore, the semantic scheme of Ch. Ogden and A. Richards, the dynamic / functional equivalence of E. Nida, classification of literary text information into three types by T. Nekryatch and Y.Chala, linguistic experience of componential analysis application (R. Jacobson, M. Kochergan, A. Kuznetsov, I. Kobozeva), 
R. Jackendoff's conceptual semantics models, conceptual equivalence as trnaslation quality assessment criterion.

The results of conceptual componential analysis on the example of the concept of "light" led to the following conclusions: 1) the Ancient Greek concept of "light" is represented in different religions and different Christian confessions demonstrating verbal continuity through religious and conceptual changeability, e.g., from polytheistic Slavonic paganism to nowadays' Christian confessions of Ukraine; 2) the verbalized concept of "light" sometimes knit together several religions into one text, e.g.,the

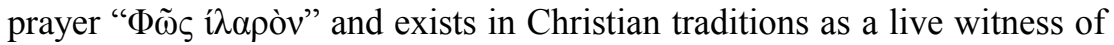
the former epochs; 3) the concept of "light" in a polytheistic religion is "reincarnated" in a monotheistic one, e.g., light of the sun is a giving life spirit of pagan god Dazhdboh (God of Sun) and the burning of the heaven fire of Svaroh).

Corpus-based conceptual seme analysis of verbalized religious concepts would facilitate the interrelations on the level of conceptual seme equivalence study. This idea found its realization in the mutual interdisciplinary project dedicated to the adaptable corpus development aimed at fulfillment of corpus-based componential concept analysis.

\section{SUMMARY}

This chapter studies a quality assessment criterion of specialist's translation based on translation analysis of the 4th century religious texts. A short historical outline of translatability issues in biblical and Christian literature translation led to the conclusion that religious translation has been facing mostly the same set of issues since that time till nowadays. The division of religious text information into three types underlines different nature of such texts themselves and proves that conceptual type of information is the frame on which other two types are based. Conceptual equivalence is used as an additional quality assessment criterion to evaluate already translated texts on the level of concept adequacy. Elements of componential and comparative analysis revealed some inadequacies in conceptual source and target language semes. The idea of corpus-based concept analysis with the help of parallel corpora or similar to FrameNet tools would facilitate the comparison of two or more texts on the level of their conceptual semes. 


\section{REFERENCES}

1. Вечірня пісня Синові Божому/Молитви богослужбові 3 вечірні. [Online]. Available: https://parafia.org.ua/biblioteka/molytvy/ pravoslavnyj-molytoslov/molytvy-bohosluzhbovi-z-vechirni.

2. Дэвидсон Д. Об идее концептуальной схемы / Д. Дэвидсон // Аналитическая философия. Избранные тексты [Сост. А.Ф. Грязнов]. М.: Изд-во МГУ. - 1986 - С. 144-159.

3. Иероним Стридонский. Письмо LVII. К Паммахию о наилучшем способе перевода / Иероним Стридонский; [пер. с латыни Н. Холмогоровой, под редакцией М. Касьян и Т. Миллер] // Альфа и Омега. № 4(7). - 1995. - С. 173-187.

4. Коптілов В. В. Теорія і практика перекладу. Навчальний посібник / Віктор Вікторович Коптілов. - К. : Юніверс, 2003. - 280 с. C. 4-58.

5. Некряч Т. Є. Через терни до зірок : труднощі перекладу художніх творів. Для студентів перекладацьких факультетів вищих навчальних закладів : навчальний посібник / Т. С. Некряч, Ю. П. Чала. Вінниця : Нова Книга, 2010. - 195 с.

6. Попович Н. М. Давньогрецька тринітарна термінологія у різномовних перекладах (На матеріалі патристичної літератури IV століття): монографія / науковий редактор проф. Клименко Н. Ф. Ужгород: Видавництво УжНУ «Говерла», 2018. - 309 с.

7. Lutskiv A., Popovych N. (8-11/10.2019). Adaptable Text Corpus Development for Specific Linguistic Research in Proc. of 2019 IEEE International Scientific and Practical Conference "Problems of Infocommunications. Science and Technology".

8. Kübler S. and Zinsmeister H., Corpus Linguistics and Linguistically Annotated Corpora (Englisch), New York; London: Bloomsbury Academic, 2015, P. 21-156. http://dx.doi.org/10.5040/9781472593573.

9. Naudé J., Religious translation / J. Naudé // Handbook of Translation Studies,ed. Yves Gambier and Luc van Doorslaer. Amsterdam / Philadelphia: John Benjamins Publishing Company. - Vol. 1. - 2010. - 458 p. P. 285-292.

10.Nida, Eugene A., Charles R. Taber. (1969). The Theory and Practice of Translation, With Special Reference to Bible Translating, 200. Leiden: Brill. - P. 1-55.

11. Nida E. A. Towards a science of translating. With special reference to principles and procedures involved in Bible translating / E. A. Nida. Leiden : Brill, 1964. - 331 p.

12. Ruppenhofer J., Ellsworth M., Petruck M. R. L, Johnson Ch. R., Baker Collin F., Scheffczyk Jan, FrameNet II: Extended Theory and 
Practice (Revised November 1, 2016.). [Online]. Available: https://framenet.icsi.berkeley.edu/fndrupal/the_book.

13. The Unabbreviated Horologion, Jordanville, New York: Holy Trinity Monastery (published 1997), 1992. P. 192-193.

\section{Information about the author:}

Popovych N. M.,

Doctor of Philosophy in Theory of Translation

(Candidate of Philological Sciences), Associate Professor at the Department of Multicultural Education and Translation of the State University "Uzhhorod National University"

14, Universytetska str., Uzhhorod, 88000, Ukraine 


\section{LEXICAL AND SEMANTIC FEATURES OF GEOLOGY TERMS IN ENGLISH}

\section{Rohach L. V.}

\section{INTRODUCTION}

Terminology has always been the object of linguistic investigation. It can be explained by the fact that terms are always used by the speakers of many languages, they can be found in manuals of many spheres of human activities. Many terms have become lexical units of common language, because of the extreme development of modern science. Terminology is a separate subsystem of lexicology. The main tendencies of lexicology of national language are reflected in terminology.

Semantics is central in the study of communication. As communication becomes more and more a crucial factor in social organization, the need to understand it becomes more and more pressing. Nowadays, undeniable is the statement about the primacy of linguistic content over form, the primacy of the lexical basis in the word and the possibility of applying semantic approach to the formalized study of all levels of language ${ }^{1}$.

The importance of the present research is dictated by the need of investigating English terminological system of geology with application of the methodology of formalized analysis of lexical semantics, that in our research presupposes distinguishing the meanings of lexical units in common language and terminological system, the study of correlation between different terminological systems and different semantic phenomena of terminology.

The object of the research is 74 English terms of geology with the explanation of their special and common meanings, 77 semes that were singled out from the meanings of the English lexical units. The subject of the research is detecting the semantic characteristics of the English lexical units being the members of terminological system of geology and a part of common language lexical layer. In our investigation, we present the characteristics of these meanings by means of describing the matrix, constructed according to the principle of rank arrangement of the components of meanings.

${ }^{1}$ Сорока Т.В. Семантика найбільш багатозначних англійських аксіономерів // Сучасні дослідження з іноземної філології. Вип 12. 2014. С. 189. 
The structure and system of literary language are most naturally and extensively represented by dictionaries, where the content of lexical units is covered in a comprehensive way. Taking into account that "in the dictionaries modern linguistics receives the most reliable and polished material for formalized analysis of lexical semantics" 2 , we have used English explanatory dictionaries as a basis for the research. The specificity of terminological studies prompted the necessity of investigation of terminological dictionaries, which helped to define the peculiarities of the analyzed lexical units and state the characteristics of their dictionary representation. We strongly support the statement that "terminography as an integrative discipline about the practice and theory of special terminological dictionaries compilation is a branch located at the intersection of lexicography, terminology, and a specific professional discipline” ${ }^{3}$.

Semantic analysis of geology terms is performed on the basis of lexicographic sources, such as explanatory dictionary Longman Dictionary of Contemporary English and terminological dictionaries McGraw-Hill Dictionary of Earth Science and McGraw-Hill Dictionary of Geology and Mineralogy.

Relying on dictionary definition in semantic studies has its obvious advantages. They are as follows: 1) when paraphrasing and semantically expanding a dictionary entry none of the components of definitions are excluded; 2) the methodology provides the opportunity to recognize the identities and differences of the structures of lexical units' meanings based on the identities and differences of their periphrases; 3) it becomes possible to operate a great number of lexical units, practically the whole dictionary.

\section{Componential analysis as a method of semantic study of lexical units of different structure}

The phenomenon of polysemy proved to be extremely important in our research as it is the basis of semantic structure of the majority of lexical units under analysis. In this study we treat polysemy as both a common language phenomenon and a terminological one.

Most English words are polysemantic, i.e. are characterized by more than one lexical meaning or lexico-semantic variants depending on the context of their usage. In scientific literature polysemy is viewed as "the existence in a word of several interconnected meanings that have one

2 Пещак М.М. Специфіка формальних ознак лексикографічної обробки слова // Формалізовані основи семантичної класифікації лексики. - Київ: Наукова думка, 1982. С. 10.

${ }^{3}$ Іваницький Р.В. Лексикографічні аспекти нормалізації термінів (на матеріалі німецьких, англійських, українських та російських термінологічних одиниць). - Львів, 1995. С. 6. 
or more common semantic components" ${ }^{4}$. Y.Kuznetsova defines a polysemantic word as "a cluster of several semantic variants of meaning related to one lexeme" 5 . These variants or separate meanings form a semantic word paradigm, are semantically connected and can be realized in different typical contexts.

Any polysemantic word is characterized by the system of meanings that develops gradually, mostly over the centuries, as more and more new meanings are added to old ones, or some of them become extinct. Thus, the complicated processes of polysemy development involve both the emergence of new meanings and the loss of old ones. Yet, the general tendency with English vocabulary at the modern stage of its history is to increase the total number of its meanings and in this way to provide for a quantitative and qualitative growth of expressive resources of the language.

Polysemy is inherent in the very nature of words and concepts as every object and every notion has many features and a concept reflected in a word always represents generalization of several features of the object. Some of such features or components of meaning are common with other objects. Hence the possibility of using the same name in secondary nomination for objects possessing common features which are sometimes only implied in the original meaning. A word when acquiring new meaning or meanings may also retain, and most often it does retain the previous meaning. The semantic structure of a word should be investigated at both levels: 1) of different meanings; 2) of semantic components within each separate meaning. For a monosemantic word (word characterized by one meaning) the first level is naturally excluded. Semantic structure of the words - is the unity of all its meanings: grammatical forms and each individual meaning of polysemantic words ${ }^{6}$.

Polysemy in our research is viewed as the phenomenon when a word has more than one meaning that are characterized by different connections. In this respect words are not isolated in the language system but are interrelated with other semantic groups of words. In the course of time meanings of lexical units acquire different shades and even change, though retaining a certain relationship.

Modern semantics treats a separate word meaning as a complex entity having its own structure. Elaboration of this idea in practical aspect led to the emergence of methodology of componential analysis, which is widely applied in the investigations dealing with lexical semantics.

${ }^{4}$ Харитончик 3.А. Лексикология английского языка. - Минск: Вышейшая школа, 1992. C. 48.

${ }^{5}$ Кузнецова Е.В.Лексикология русского языка. - М.: Высшая школа, 1989. С. 101.

${ }^{6}$ Cruise D.A. Monosemy vs. polysemy: Linguistics. - Cambridge, 1992. P. 256. 
As an independent method in linguistics componential analysis appeared in the late 50ies of the 20 century. The term itself belongs to W. Goodenough. This method is based on defining differential meaning components for the opposition of the words, which have the common semantic part ${ }^{7}$.

Componential analysis is particularly applicable to distinguish the meanings of lexemes that are semantically related or in the same semantic domain. It is based on the presumption that the meaning of a word is composed of semantic components. So the essential features that form the meaning are elementary units on semantic level. By componential analysis, it is possible to state the smallest indivisible units of lexis or minimal components $^{8}$. It is often seen as a process of breaking down the sense of a word into its minimal distinctive features; that is, into components which contrast with other components. It refers to the description of the meaning of words through structured sets of semantic features, which are given as "present”, "absent”, or "indifferent with reference to feature"”.

According to different authors minimal semantic units, that are the basis of componential analysis, are called semantic components, semantic features, seme, plereme, noema, semantic units, and so on. The components of meaning are viewed in componential analysis as atomic concepts. The lexical unit, seen as an independent entity, is not put under a separate analysis, but in its possible linguistic paradigmatic and syntagmatic links ${ }^{10}$. Componential analysis results in the selection of semes that are a part of words' lexical meanings being rigidly organized structures. A seme is a minimal unit of sense, an atom of lexical semantics distinguished on the basis of oppositions by method of componential analysis. A seme is not expressed in a word in any material unit but it's revealed and singled out through interrelations of the word with other words on a paradigmatic and syntagmatic levels.

In our investigation we understand a seme as a semantic microcomponent which reflects the specific features of the notion represented by the word. Each seme as a microcomponent of meaning is composed of two principal parts (components) - the semantic feature and seme specifier. The seme specifier is the part of the seme which specifies the particular semantic feature.

${ }^{7}$ Goodenough W.H. Componential Analysis and the Study of Meaning. Language 32(1), 1956. P. 210.

${ }^{8}$ Aitchison Jane. Linguistics. - London: Hodder and Stoughton, 2003. P. 92.

${ }^{9}$ Saeed, John. Semantics. - United Kingdom: Wiley Blackwell, 2009. P. 260.

${ }^{10}$ Enesi M. Strati K Contemporary methods of semantic studies and their impact in translation // Interdisiplinary Journal of Research and Development, Vol. 4. № 3. 2017. P. 121-122. 
There are two types of componential analysis: minimal and full. Minimal componential analysis of a group of words is a simple method that defines divergences in the semantics of words. As a rule, it is used in such cases when it is necessary to distinguish the meanings of synonyms or groups of semantically close words. The method is being implemented until each word has its own set of semes. The goal of full componential analysis is not the division of word meanings, as it is characteristic of minimal componential analysis, but the full defining of the seme structure of a sememe. Full componential analysis is carried out by means of dictionary definitions with attraction of the whole lexico-semantic group of words, to which an investigated unit belongs. In full componential analysis all the units of the given lexico-semantic group fall under analysis.

The linguists have different viewpoints on the very essence of componential analysis. I.V. Arnold states that componential analysis is a procedure when the meaning of a great number of lexico-semantic variants is described by means of limited inventory of semantic units ${ }^{11}$. Componential analysis is also characterized as a method of investigation the meaningful side of lexical units of language that is elaborated within the framework of structural semantics and aims at decomposing meanings into minimal semantic components ${ }^{12}$.

The essence and purpose of method of componential analysis in our research lies in the fact that meanings of terms are segmented into features by which some lexical units are distinguished from each other, the other, on the contrary, are grouped or aggregated. We treat componential analysis as one of the main ways of revealing of the inner structure of the language especially of its lexical composition.

A seme is viewed as the minimum unit of meaning, which is not selfsufficient, because it cannot be realized independently, but only within another semantic size, inside sememe (which appears as an inclusive unit as opposed to seme, as an 'included' unit). According to the conception, sememe is formed by a group of semantic features ${ }^{13}$.

The problem of investigating the mechanisms of term formation and the links between the seme structure and the common semantic component, studying the influence of these multilevel relationships on the processes of functioning and evolution of the term in different terminological systems occupies a significant place in modern semantic

\footnotetext{
${ }^{11}$ Арнольд И.В. Семантическая структура слова в современном английском языке и методика ее исследования. - Л.: Просвещение, 1966. С. 80.

${ }^{12}$ Leech G. Semantics. - London: Penguin Books, 1975. P. 98.

${ }^{13}$ Enesi M. Strati K Contemporary methods of semantic studies and their impact in translation // Interdisiplinary Journal of Research and Development, Vol. 4, no. 3, 2017. P. 121-122.
} 
research $^{14}$. In this respect it is relevant that the study of semantics of the English geology terms as both common language and terminological units revealed that the meanings of terms are characterized by certain semantic features testifying to obvious dissimilarity of some terms, and, on the contrary, the similarity of other, being thus united into groups.

A word, that in our research is both a common language lexical unit and a term, presents not simply the totality of knowledge, but forms a generalized semantic image. All the meanings taken together, the relationships between them and the words associated with them form a certain semantic space inside which one can distinguish separate semantic centres.

We view semantic space as a common semantic basis, which "in combination with the acoustic-graphic image provides it with integrity, economy of storage in memory and dynamism in communication”" Semantic space of English geology terminological lexis is a continuous and heterogeneous phenomenon. This heterogeneity reveals the potential for the emergence of new semantic centres due to contraction or distancing at any place of this space. As a result of this process, new terminological vocabulary arises, which eventually becomes a lexical-semantic variant of the semantic structure of the word.

\section{Lexical peculiarities of geology terms in the English language}

English terms of geology that constitute research language material were selected from terminological dictionaries of geology and their common language semantics was observed in the explanatory dictionaries. Linguistic method of componential analysis was applied to examine the geology terms' common language and special semantics. In order to achieve this aim we singed out semes from commonly used and terminological meanings. Methodology of formalized analysis of lexical units' semantics was applied to investigate semantic peculiarities of English terms of geology. Matrix of semantic space of English geological terms was constructed. It presents the terms, arranged in horizontal lines and semes, set in vertical lines order. On the crossing of the rows and columns, we indicate the existence of seme realizations in the investigated meanings. The ordering of the whole seme stock of the investigated material was carried out on the basis of quantitative criterion. The most widely occurring semes are placed at the beginning of the table, the semes with an average degree of occurrence and monofunctional semes are found

\footnotetext{
${ }^{14}$ Алієва О. Спільний інваріантний компонент: формування семантичної та концептуальної структури терміна // Сучасні дослідження з іноземної філології. Вип. 13. 2015. С. 269.

${ }_{15}$ Фабіан М.П. Етикетна лексика в українській, англійській та угорській мовах. Ужгород: Інформаційно-видавниче агентство «IBA», 1998. С. 123. 110
} 
at the end of the arranged list. The investigated English terms of geology are placed in the decreasing order - from the most polysemantic lexical unit to the monosemantic ones. According to the matrix three groups of terms can be distinguished: lexical units with wide semantics, lexical units with average degree of semantics and lexical units with narrow semantics (monosemantic).

The group of lexical units characterized by the highest degree of polysemy consists of the following terms bank, bar, bed, contact, aspect, ball, basin, depression, floor, consolidation, earth, face, fan, gap. Semantic structure of these lexical units comprise from 9 to 5 meanings in the dictionary entry. To show the difference between common language and special semantics of the first group of geology terminological units we have selected the following examples.

Common language word contact denotes communication with a person, organization, country; when two people or things touch each other; when you meet someone or experience a particular kind of thing; a person you know who may be able to help or advise you; an electrical part that completes a circuit when it touches another part; contact lens ${ }^{16}$. As a terminological unit contact is used in the meaning the surface between two different kinds of rocks ${ }^{17}$. The common semantic component of these meanings can be defined as somebody or something touching. It is quite obvious that the term contact was formed by means of semantic way of term formation or terminologization.

Common language meanings of the word basin are as follows: a round container attached to the wall in a bathroom, where you wash your hands and face; a large bowl-shaped container for liquids or food; the amount of liquid that a basin can contain; an area of land that is lower at the centre than at the edges; a place where the Earth's surface is lower than in other areas. Terminological dictionary of geology defines the term basin as a polysemantic one meaning: a low-lying area, wholly or largely surrounded by higher land, that varies from a small, nearly enclosed valley to an extensive, mountain-rimmed depression; an entire area drained by a given stream and its tributaries; an area in which the rock strata are inclined downward from all sides toward the center; an area in which sediments accumulate ${ }^{18}$. In oceanography basin is understood as deep portion of sea surrounded by shallower regions ${ }^{19}$. The meanings included into explanatory dictionary implicitly define this word as a term of geology.

\footnotetext{
${ }^{16}$ Longman Dictionary of Contemporary English. - Longman Group Ltd, 2000.

${ }^{17}$ McGraw-Hill Dictionary of Earth Science [Electronic resource]: yunus.hacettepe.edu.tr.

${ }^{18}$ Longman Dictionary of Contemporary English. - Longman Group Ltd, 2000.

${ }^{19}$ McGraw-Hill Dictionary of Earth Science [Electronic resource]: yunus.hacettepe.edu.tr.
} 
Depression in common language is used in the following meanings a medical condition that makes you very unhappy and anxious and often prevents you from living a normal life; a long period during which there is very little business activity and a lot of people did not have jobs; a part of a surface that is lower than the other parts; a mass of air under low pressure, that usually causes rain ${ }^{20}$. Geological term depression is fixed in the dictionary as a hollow of any size on a plain surface having no natural outlet for surface drainage; a structurally low area in the crust of the earth. In meteorology it is an area of low pressure; usually applied to a certain stage in the development of a tropical cyclone, to migratory lows and troughs, and to upper-level lows and troughs that are only weakly developed $^{21}$. The seme part of a surface is common in the semantic structure of depression as a common language word and a term of geology, what testifies to the semantic way of term formation in this case.

Consolidation is a common language lexical unit which denotes unity of some forces and position of power or success. In business the term consolidation is used in the meanings: 1) when companies combine in takeovers resulting in fewer businesses; 2) when organizations or departments become joined together; 3) when a company's position of power or success is made stronger and more likely to continue ${ }^{22}$. As a term of geology consolidation means 1) processes by which loose, soft, or liquid earth become coherent and firm; 2) adjustment of a saturated soil in response to increased load; involves squeezing of water from the pores and a decrease in void ratio ${ }^{23}$.

The analysis of the first group of lexical units of our language material shows that the semantic structure of the English terms of geology is rather broad containing several meanings. The conclusion can be made that terminological meanings of these words are derived from the common language ones on the basis of common semantic feature. Thus, terms of geology of this group of our material were formed by means of terminologization. A distinctive feature of geological terms of this group is that the majority of them are polysemantic terminological units containing at least two special meanings in their semantic structure. Semantics of lexical units of this group is also characterized by strong scientific character as a lot of geology terms of this group are the terms of other branches of human activity, especially of such related spheres as oceanography, meteorology and hydrology. The performed formalized

\footnotetext{
${ }^{20}$ Longman Dictionary of Contemporary English. - Longman Group Ltd, 2000.

${ }^{21}$ McGraw-Hill Dictionary of Earth Science [Electronic resource]: yunus.hacettepe.edu.tr.

${ }^{22}$ Longman Dictionary of Contemporary English. - Longman Group Ltd, 2000.

${ }^{23}$ McGraw-Hill Dictionary of Earth Science [Electronic resource]: yunus.hacettepe.edu.tr.
} 
analysis allows us to state that in the semantic space of this group of English geology terms the majority of meanings are conveyed by multifunctional semes.

The second group of polysemantic lexemes in our language material is the most numerous one comprising 35 units. The second group represents the English geology terminological units with average degree of polysemy. The common language semantic structure of these words contain from 4 to 2 meanings. It consists of the following terms: abstraction, accretion, age, basement, bend, degradation, assimilation, axis, backbone, erosion, event, finger, descendant, advance, deflation, bench, cap rock, cay, correlation, arm, closure, chimney rock, clast, clay, annual layer, episode, accumulation, basset, declivity, berm, blind etc.

The analysis showed that lexical unit accretion is not used in common language meanings being characterized by two special meanings in geology: 1) gradual buildup of land on a shore due to wave action, tides, currents, airborne material, or alluvial deposits; 2) the process whereby stones or other inorganic masses add to their bulk by adding particles to their surfaces; and one special meaning in meteorology: the growth of a precipitation particle by the collision of a frozen particle (ice crystal or snowflake) with a supercooled liquid droplet which freezes upon contact ${ }^{24}$.

Lexical unit assimilation in the explanatory dictionary is fixed in the following meanings: 1) the process of understanding and using new ideas; 2) politics the process of becoming an accepted part of a country or group; 3) linguistics a phonetical process, in which two phonemes adjacent or very near to each other acquire common characteristics or become identical ${ }^{25}$. In special geological dictionary assimilation denotes incorporation of solid or fluid material that was originally in the rock wall into a magma ${ }^{26}$. It is clear, that this word has a strong scientific character being the term of several sciences.

The term of geology backbone is characterized by the following common language meanings: 1) the row of connected bones that go down the middle of your back; 2) courage and determination ${ }^{27}$. In geology the term backbone originated from the common language meaning of the row of connected bones that go down the middle of your back and denotes 1) a ridge forming the principal axis of a mountain; and 2) the principal

\footnotetext{
${ }^{24}$ McGraw-Hill Dictionary of Earth Science [Electronic resource]: yunus.hacettepe.edu.tr.

${ }^{25}$ Longman Dictionary of Contemporary English. - Longman Group Ltd, 2000.

${ }^{26}$ McGraw-Hill Dictionary of Earth Science [Electronic resource]: yunus.hacettepe.edu.tr.

${ }^{27}$ Longman Dictionary of Contemporary English. - Longman Group Ltd, 2000.
} 
mountain ridge, range, or system of a region ${ }^{28}$. As far as this term has two meanings in the sphere of geology we would suggest adding these terminological meanings to common language ones marking them by the lexicographical note geology.

Lexical unit finger is fixed in terminological dictionary in the following meanings: 1) one of the four long thin parts on your hand, not including your thumb; 2) the part of a glove that covers your finger; 3) anything that is long and thin, like the shape of a finger, especially a piece of land, an area of water, or a piece of food ${ }^{29}$. Terminological meaning of the lexical unit finger originated from the capacity of fingers to move forward irregularly (the tendency for gas which is displacing liquid hydrocarbons in a heterogeneous reservoir rock system to move forward irregularly (in fingers), rather than on a uniform front ${ }^{30}$ ). We consider the geology term finger to be formed by semantic way of term formation on the basis of similarity of functions of these concepts.

Bench as a common language lexical unit has the following meanings: 1) a long seat for two or more people, especially outdoors; 2) a long heavy table used for working on with tools or equipment ${ }^{31}$. In our opinion these meanings were taken as a basis when the geology term bench was formed as far as the terminological meaning a terrace of level earth or rock that is raised and narrow and that breaks the continuity of a declivity has a strong resemblance to the common language ones.

In common language the word arm is used in the following meanings: one of the two long parts of your body between your shoulders and your hands; the part of a chair, sofa ${ }^{32}$. The term of geology arm was formed on the basis of similarity of the form of these two concepts as in geology arm is a ridge or a spur that extends from a mountain. In oceanography it is a long, narrow inlet of water extending from another body of water ${ }^{33}$.

The most vivid features of geological terms of the second group of average degree of polysemy are as follows:

1) terminological polysemy of the majority of terms of geology in this group;

2) the phenomenon when terminological meaning in geology implicitly or explicitly resembles the common language one, thus we can conclude that such term was formed by semantic way of term formation;

\footnotetext{
${ }^{28}$ McGraw-Hill Dictionary of Earth Science [Electronic resource]: yunus.hacettepe.edu.tr.

${ }^{29}$ McGraw-Hill Dictionary of Earth Science [Electronic resource]: yunus.hacettepe.edu.tr.

${ }^{30}$ Ibid.

${ }^{31}$ Longman Dictionary of Contemporary English. - Longman Group Ltd, 2000.

32 Ibid.

${ }^{33}$ McGraw-Hill Dictionary of Earth Science [Electronic resource]: yunus.hacettepe.edu.tr.
} 
3) the possibility of introducing terminological meaning in geology into the explanatory dictionary and labeling it by the lexicographical note geology;

4) in the semantic space many terms of this group are united by the semantic feature related spheres designating intersystem terminological polysemy in such related earth sciences as oceanography, hydrology and meteorology.

One and the same term can be used in several terminological systems. Simultaneous usage of one term in mathematics, chemistry, medicine, biology, jurisprudence, logic, physics, philosophy, etc. in our opinion is the display of intersystem terminological polysemy. This can be accounted for the similarity of semantic processes in different spheres of human activity.

The third group of lexical units in our material contains monosemantic terms of geology having narrow special semantics. The examples of monosemantic lexical units of our material are as follows: base level - that critical plane of erosion and deposition represented by river level on continents and by wave or current base in the sea; cavern - an underground chamber or series of chambers of indefinite extent carved out by rock springs in limestone; cluse - a narrow gorge, trench, or water gap with steep sides that cuts transversely through an otherwise continuous ridge; cluse - a narrow gorge, trench, or water gap with steep sides that cuts transversely through an otherwise continuous ridge; denudation general wearing away of the land; laying bare of subjacent lands.

The peculiarity of this group of words is that some of the terms are not registered in the explanatory dictionary as they don't have common language meanings at all. Some of the terms are fixed in this type of lexicographical source being implicitly defined as the terms of geology but not labeled as the ones referring to this sphere.

\section{Seme Analysis of English Terms of Geology}

The matrix constructed on the basis of lexical and seme composition of the English geology terms represents the structure of semantic space of geology terminology in the system of common language. From the meanings of 74 geology terms 77 semes were selected. On the basis of quantitative criterion the semes were divided into three main groups: polyfunctional semes, semes of average degree of occurrence and monofunctional semes.

The analysis showed that the following semes are polyfunctional in our material: land, ground; part of, portion; rock; process, action; expressions; science; close sphere; something; period, time; area; ridge; 
person. These semes are the components of meanings of from 13 to 5 geology terms.

The seme land, ground unites the meanings of 13 words in our material: bank, bed, floor, consolidation, earth, accretion, degradation, erosion, bench, denundation, geanticline, geocosmogony, macropore. In the majority of meanings this seme represents terminological meaning in the sphere of geology. For example: accretion - gradual buildup of land on a shore due to wave action, tides, currents, airborne material, or alluvial deposits; degradation - the wearing down of the land surface by processes of erosion and weathering; erosion - the wearing away of the land, chiefly by rain and running water ${ }^{34}$. In the semantic structure of the terms bank and earth the seme land, ground unites terminological and common language meanings.

The seme part, portion was singled out from the meanings of 12 lexical units: bar, contact, aspect, basin, floor, earth, face, abstraction, axis, arm, clast, berm. In the semantics of 5 words this seme bears terminological character. For example: clast - an individual grain, portion, fragment, or constituent of detrital sediment or sedimentary rock produced by physical breakdown of a larger mass; berm - a horizontal portion of a beach or backshore formed by deposit of material as a result of wave action. Semantics of the majority of lexical units united by this seme is of common language character. For example: aspect - one part of a situation, idea, plan etc that has many parts; arm - one of the two long parts of your body between your shoulders and your hands.

The seme rock in our material unites terminological semantics of the following words: bar, bed basin, floor, basement, assimilation, cap rock, clast, ablation moraine, basset, allochthon. For example: ablation moraine - a layer of rock particles overlying ice in the ablation of a glacier; assimilation - incorporation of solid or fluid material that was originally in the rock wall into a magma; basin - an area in which the rock strata are inclined downward from all sides toward the center ${ }^{35}$.

The semantic feature of process, action was singled out from the semantics of 11 lexical units: abstraction, accretion, bend, degradation, assimilation, erosion, deflation, correlation, abration, accumulation, icerafting. In the majority of cases this seme bears terminological character. For example: accretion - the process whereby stones or other inorganic masses add to their bulk by adding particles to their surfaces; deflation the sweeping erosive action of the wind over the ground; ice-rafting - the

\footnotetext{
${ }^{34}$ McGraw-Hill Dictionary of Earth Science [Electronic resource]: yunus.hacettepe.edu.tr.

${ }^{35}$ Ibid.
} 
process of transporting of rock and other minerals, of all sizes, on or within icebergs, ice floes, river drift, or other forms of floating ice. In the semantic structure of the words assimilation and erosion the seme process, action has both terminological and common language character. For example, terminological meaning of the word erosion is - the process by which rock or soil is gradually destroyed by wind, rain, or the sea. Common language meaning of this lexical unit is - the process by which something is gradually reduced or destroyed.

Semantic feature of scientific character of the words under analysis was marked in our language material by two semes science and close spheres as far as geology is closely connected with such earth sciences as meteorology, hydrology and oceanography. Thus, the seme science in our material denotes the meanings of words in distant sciences such as politics, linguistics, economics ect. and the seme close spheres in such sciences as meteorology, hydrology and oceanography. The seme science unites semantics of the following terms: bank, aspect, consolidation, earth, assimilation, axis, deflation, dendrochronology. For example: aspect linguistics the form of a verb in grammar that shows whether an action is continuing, or happens always, again and again, or once; bank economics a business that keeps and lends money and provides other financial services; deflation - economics a reduction in the amount of money in a country's economy, so that prices fall or stop rising. The semantic feature of close spheres unites semantics of the following terms: bank, bed, basin, depression, accretion, arm, abration. For example: depression in meteorology is an area of low pressure; bank in oceanography is a relatively flat-topped raised portion of the sea floor occurring at shallow depth and characteristically on the continental shelf or near an island.

The seme ridge is a purely terminological one in our language material denoting special meaning in geology. The following terms are united by this semantic feature: bank, bar, ball, backbone, arm. For example: bar any of the various submerged or partially submerged ridges, banks, or mounds of sand, gravel, or other unconsolidated sediment built up by waves or currents within stream channels, at estuary mouths, and along coasts; ball - a low sand ridge, underwater by high tide, which extends generally parallel with the shoreline; usually separated by an intervening trough from the beach; arm - a ridge or a spur that extends from a mountain $^{36}$.

\footnotetext{
${ }^{36}$ McGraw-Hill Dictionary of Earth Science [Electronic resource]: yunus.hacettepe.edu.tr.
} 
The second group of semantic components in our material are the semes of average degree of occurrence. This group comprises 24 semes. We have singled them out of the meanings of four, three and two lexical units. They are as follows: amount of, quantity; place, position; surface; deposit; movement; deviation, difference; money; mass; body; material; state of, condition; layer; line, curve; mountain, slope; production; feature; ash; furniture; sand; reef, cliff; distance, touch; base; experience.

The seme amount of, quantity unites the meanings of 4 lexical units: bank, age, accumulation, abundance. In the semantic structure of accumulation and abundance this seme bears both common language and terminological character. For example: accumulation in terminology is the quantity of snow or other solid form of water added to a glacier or snowfield, such as by precipitation, wind drift, or avalanches and in common language the amount of something that collects or is collected over time. The term of geology abundance is explained as the relative amount of a given element among other elements and as a common language word - a large quantity of something.

The semes sport and body unite the following terms in the semantic space of geology terms: sport - bar, ball, event; body - bank, floor, cap rock. The characteristic feature of semantics of these terms is that sport in the meanings of all the terms is a common language feature whereas body - terminological one. For example: event - one of the races or competitions that are part of a large sports competition; ball - any game or sport played with a ball, especially baseball or basketball; cap rock an impervious body of anhydrite and gypsum in a salt dome; floor a horizontal, flat ore body.

The seme layer unites the following terms in the semantic space of geology terms: basement, annual layer. The seme line, curve unites terminological meanings of the words bend and axis. The semantics of these terms is located nearby in the semantic space of English geology terms. For example: annual layer - a sedimentary layer deposited, or presumed to have been deposited, during the course of a year; a line where a folded bed has maximum curvature; bend - a curve or turn occurring in a stream course, bed, or channel which has not yet become a meander; axis - a line where a folded bed has maximum curvature ${ }^{37}$. As we can see, these semes bear a purely terminological character in the semantic space of geology terms.

The semes of the third group unite the monofunctional semantic elements in our language material. This group contains 34 monofunctional

\footnotetext{
${ }^{37}$ McGraw-Hill Dictionary of Earth Science [Electronic resource]: yunus.hacettepe.edu.tr.
} 
semes. In our study they were detected in only one lexicographic explanation. They are as follows: drift; form; idea; name; sediment; direction; water; colour; appearance; erosion; subdivision; container; dog; elevation; seat; terrace; shelter, covering; flower; bed; matter; courage; island; chamber; column; fraction; end; gap; department; progress; communication; determination; connection; depression; disappearance. The majority of these semes are of terminological character.

The terms that contain the abovementioned semes in their semantic structure have no connections with other words in our material and are located separately in the semantic space.

The results of the performed semantic analysis are presented in the constructed matrix of semantic space of geology terms in the English languages. The matrix illustrates the semantic structure of geological terminology in English on the background of common language. The first part of the matrix is characterized by dense localization of semes. In the left upper part the realization of frequently used semes and lexical units with wide sematics is presented. This testifies to their significant semantic value in the semantic space of language. In this place of the matrix one can vividly see that the special semantics of English geology terms in many cases coincides with that of common vocabulary one, thus the concretization is needed for their identification. The left lower part of the matrix presents lexical units with average and narrow degree of semantics and correspondingly semes with average degree of occurrence and monofunctional ones. In the right part of the matrix we can observe relatively small number of seme realizations which are of both terminological and common language character.

\section{CONCLUSIONS}

The research is aimed at determining semantic peculiarities of the English terminology of geology in its different connections, in particular specific terminological and common language ones. The achievement of this aim preconditioned the application of componential analysis and the methodology of formalized analysis of lexical semantics of the investigated terminological units. The semantics of the geology terms was performed on the basis of terminological and explanatory dictionaries.

The construction of the matrix of semantic space of geology terms allowed us to divide terms into three groups according to the degree of their semantics: lexical units with the highest degree of polysemy, lexical units characterized by the average degree of polysemy and monosemantic terms. The first group of our material is not numerous, but the elements forming it have rather broad semantics containing a lot of meanings. 
Terminological meanings of this group in their majority are derived from the common language ones, thus the English geological terms of this group were formed by means of terminologization. The most vivid features of geological terms of the group of average degree of polysemy are as follows: terminological polysemy of the terms; the possibility of introducing terminological meaning in geology into the explanatory dictionary and labeling it by the lexicographical note geology; in the semantic space terms are united by the semantic feature related spheres designating intersystem terminological polysemy. The third group of lexical units in our material consists of monosemantic terms of geology having narrow special semantics. The peculiarity of this group of words is that some of the terms are registered in the explanatory dictionary being implicitly defined as the terms of geology but not labeled as the ones referring to this sphere.

The seme analysis of the language material enabled us to classify semes according to the quantitative parameter. We distinguish polyfunctional semes, semes with the average degree of occurrence and monofunctional. The group of polyfunctional semes occupies the first place in the matrix. The analysis shows that all the semes of this group have terminological character, only in some instances their terminological and common language functions coincide. The second and the third groups of our language material comprise the semes that have both terminological and common language character.

The results of the performed semantic analysis are presented in the matrix of semantic space of the English terms of geology that illustrates the semantic structure of geological terminology in English on the background of common language. Dense location of seme realizations in the left upper part of the matrix testifies to their significant value in the semantic space of language; concretization is needed for the identification of terminological semantics. The left lower part of the matrix presents lexical units with average and narrow degree of semantics displaying isolation in the semantic space.

The formalized research of English geology terms' semantics enabled us to define the main features of the semantic structure of these lexical units as the elements of terminological system and common language system and revealed the possibilities of their further semantic study.

\section{SUMMARY}

The present paper deals with the study of semantic features of the English terminology of geology with application of methodology of formalized analysis of lexical semantics. The object of research is the 
English terms of geology with the explanation of their special and common language meanings taken from lexicographical sources. The investigation is aimed at determining special terminological meanings of the analysed words in the connection with their common language semantics. Application of componential analysis helped to single out semantic components (semes) from common language and terminological meanings of lexical units. Methodology of formalized analysis enabled us to construct the matrix of semantic space of English terminology of geology according to the principle of rank arrangement of the components of meaning. The matrix provided the possibility of distinguishing three groups of terms (lexical units with wide semantics, lexical units with average degree of semantics and lexical units with narrow semantics) and three groups of semes (according to the degree of their functionality). The present research helped to define different connections of terminological lexis inside geology terminological system, with terms of other domains, common language lexical units and revealed the possibilities of further semantic study of terminological lexis.

\section{REFERENCES}

1. Aitchison Jane. Linguistics. - London: Hodder and Stoughton, 2003. - 240p.

2. Cruise D.A. Monosemy vs. polysemy: Linguistics. - Cambridge, 1992. $-599 \mathrm{p}$.

3. Enesi M. Strati K. Contemporary methods of semantic studies and their impact in translation // Interdisiplinary Journal of Research and Development, Vol. 4. № 3. 2017. - P. 117-126.

4. Goodenough W.H. Componential Analysis and the Study of Meaning. Language 32(1): 1956. - P. 195-216.

5. Leech G. Semantics. - London: Penguin Books, 1975. - 386p.

6. Saeed, John. Semantics. - United Kingdom: Wiley Blackwell, 2009. - 44 3p.

7. Алієва О. Спільний інваріантний компонент: формування семантичної та концептуальної структури терміна // Сучасні дослідження з іноземної філології. Вип.13, 2015. - С. 269-273.

8. Арнольд И.В. Семантическая структура слова в современном английском языке и методика ее исследования. - Л.: Просвещение, 1966. - $192 \mathrm{c}$.

9. Іваницький Р.В. Лексикографічні аспекти нормалізації термінів (на матеріалі німецьких, англійських, українських та російських термінологічних одиниць): Автореферат дис. ... канд.філол. наук. Львів, 1995. - 20 с. 
10. Кузнецова Е.В. Лексикология русского языка. - М.: Высшая школа, 1989. - $216 \mathrm{c.}$

11. Пещак М.М. Специфіка формальних ознак лексикографічної обробки слова // Формалізовані основи семантичної класифікації лексики. - Київ: Наукова думка, 1982. - С. 10-55.

12. Сорока Т.В. Семантика найбільш багатозначних англійських аксіономерів // Сучасні дослідження 3 іноземної філології. Збірник наукових праць. - Ужгород. Вип 12. 2014. - С. 189-200.

13. Фабіан М.П. Етикетна лексика в українській, англійській та угорській мовах. - Ужгород: Інформаційно-видавниче агентство «IBA», 1998. - $256 \mathrm{c}$.

14. Харитончик 3.А. Лексикология английского языка. - Минск: Вышейшая школа, 1992. - 229 с.

\section{SOURCES}

15. Longman Dictionary of Contemporary English. - Longman Group Ltd, 2000.

16. McGraw-Hill Dictionary of Earth Science. - New York. $2^{\text {nd }}$ edition, 2003 [Electronic resource]: yunus.hacettepe.edu.tr

17. McGraw-Hill Dictionary of Geology and Mineralogy. - New York. $2^{\text {nd }}$ edition, 2003 [Electronic resource]: https://www.academia.edu/ 10260338/

Information about the author: Rohach L. V.,

Candidate of Philological Sciences, Associate Professor at the Department of English Philology,

Uzhhorod National University 14, Universytetska str., Uzhhorod, 88000, Ukraine 


\section{TO THE PROBLEM OF ETHNOTHEROTYPES AND LOCAL NICKNAMES OF THE SLAVS IN LANGUAGE AND CULTURE}

\section{Tyshchenko O. V.}

\section{INTRODUCTION}

The essence of the ethnos is manifested primarily in its culture ${ }^{1}$. This ethnographers' statement has its undoubtedly distinctive basis in ethnology, ethnopsychology. It finds its direct reflection in the language of modern and traditional culture of Slavs in the form of ethnic stereotypes, expressed in a certain system of ethnic nominations.

Ethnic names system consideration froms a pragmatic and anthropological point of view and is necessary to understanding the specific world vision and world devision which is typical to collective ethnic consciousness. The stability of the people names is connected with the very existence of the ethnic group ${ }^{2}$. That is why the analysis of Slavic vocabulary and phraseology for the designation of ethnic communities can be useful both in the ethnohistory study as well as the individual ethnic groups description, in establishing cultural relations and contacts between peoples in their historical past.

Ukrainian ethnographer M. Tivodar admits that each ethnic community has universal signs. Ethnic consciousness is "the totality of knowledge, socio-psychological attitudes, ideas about one's ethnicity, its properties and stereotypes, and its place in the modern world. It is an integrated feature that includes knowledge or understanding of one's homeland, common origin and shared historical fate. All this testifies that the ethnic communities consciousness exists in mass forms of social consciousness, that is, in language, folk art, festive rituals and everyday culture, norms of morality and law, etc." ${ }^{3}$. Ethnic consciousness is also linked to the love to the native ethnic group, its history, language, culture, religion, tradition and way of life. The characteristic feature is its attitude to the own ethnic community as the highest, that is, the best. Since the formation of primitive tribes, one can speak of the first ethnic stereotypes that were created under the influence of natural and geographical factors. Interethnic

\footnotetext{
${ }^{1}$ Пономарьов А. Українська етнографія. Курс лекцій. Київ, 1994. С. 117.

${ }^{2}$ Голикова Т.А. Стереотип как этнически и культурологически обусловленный компонент менталитета / Мир языка и межкультурная коммуникация; отв. ред. Э.Е.Курлянд. Ч.1. Барнаул: БГПУ 2001. С. 82.

${ }^{3}$ Тиводар М. Етнологія. Львів 2004. С. 69-70.
} 
conflicts of the primordial era arose mainly from ethnic bias and rejection of alien ethnic groups.

How does an ethnic group identify itself and how are other peoples and social groups perceived, including neighboring ones? Why do ethnic world models fix expressive, abusive nicknames, invectives, including ethnic nicknames? How does the principle of ethnocentrism work in the language, folklore, customs and traditional rites of the Slavs, and how is it reflected in the original ethnoculture and mythological consciousness? After all, as reflected in Slavic ethnoculture, the national linguistic world picture, the main semantic juxtaposition of own/alien, are we at the level of the ethnic group's religious and confessional consciousness? In our opinion, the reflection of the semiotic principle under consideration in the language - in its system, categories and mechanisms - should be found in the most ancient ethnic vocabulary and in figurative and evaluative language units, including nicknames.

It is the range of questions that we are going to address in the proposed exploration, based on linguistic, ethnographic and folklore facts in the Slavic linguistic and cultural continuum.

\section{Ethnic nominative units specificity within the naive world picture in anthropology, folklore, traditional folk culture}

Note that the study of ethnic names within ethnology, sociology, cultural anthropology and ethno-linguistics is closely combined with the theory of modern onomastics and ethnonymics, which has developed a number of terms for the ethnic communities designation (official, informal, abusive). Researchers claim that when "an ethnic nomination, the attribution of names to a certain type occurs by the subject of the nomination, that is, the speaker's national identity"'

To denote self-ethnicity in linguistic writings, several terms are used in parallel: "auto-ethnonym" (N. V. Vasilyev, G. M. Lyagoshniak, O. O. Rogach), "autoethnonym" (G. F. Kovalev), "endo-ethnonym" (A. S. Gerd, O. I. Kuznetsov). On the other hand, thre exist the terms used to refer to ethnic names given by other peoples, ie from outside the country. Researchers call them differently: "exogenous ethnonym" (N. V. Podolskaya), "ethnicon" (V. A. Nikonov), "exo-ethnonym" (G. M. Lyagoshniak), and such terminological designation as "exonym" (A. S. Gerd, O. I. Kuznetsov) or an external ethnonym (V. I. Suprun) ${ }^{5}$.

\footnotetext{
${ }^{4}$ Левицький А.Е., Святюк Ю.В. Етнономінації у дзеркалі міжкультурної комунікації. Монографія. Київ, 2011. С. 27.

${ }^{5}$ Ibid.
} 
Let us emphasize that the vocabulary associated with these concepts and terms conceptualizes a universal for ethnological semantic juxtaposition of "alien" through verbalized collective world and human experience knowledge, and therefore is the subject of study not only in onomastics but also in cognitive semantics, political phraseology, intercultural communication theories, cultural anthropology and ethnography.

O. Belova admits that in folk culture the attitude towards other ethnic groups representatives is largely determined by the ethnocentrism notion, when "their" traditions, "their" religion, "their" customs and "their" language are understood as the only "correct", " the righteous, the "normative," the "true," in contrast to the alien, who is perceived as "unacceptable," "sinful," and the representative of the idio-ethnic group as being dangerous and even demonic, endowed with supernatural properties ${ }^{6}$. In other words, the devision of the universe into two worlds "one's own" and "alien" - has numerous linguistic-ethnological interpretations and is implemented in oppositions of the type "we/they", "this/that", "here/there", "near/far" etc. Typical in this case is the implementation of the basic oppositions in the axiological, evaluative plan in the form of "good/bad", with a clearly negative assessment of everything that belongs to alien world.

Polish ethnolinguistic and ethnographic studies have covered in detail such features of linguistic ethno-stereotypes as selectivity, evaluativeness, associativity, generalization, and hyperbolization ${ }^{7}$. In addition, the ethnomarked semiotic model of "one's own and alien" is reflected in ethnophobisms, ethnically connotated categories of onomastic variety, case motivated texts, their semantic and communicative-pragmatic features.

Opposition "We/They" in the process of the semiotic space selforganization which reflects the sociogenesis basic rights is explored by D. I. Voronin. The researcher notes that "the genetic relationship between the consciousness formation processes and the sphere of alien domination understanding is united in a single process the crystallization of "We" as well as the structuring of the "They" vast space"... "We" and "They" contactingis provided through a suggestive influence on the dominant

\footnotetext{
${ }^{6}$ Белова О.В. Этнокультурные стереотипы в славянской народной традиции. Москва, 2005. C. 7.

${ }^{7}$ Bartmiński J., Lappo I. U. Majer-Baranowska Stereotyp Rosjanina i jego profilowanie we współczesnej polszczyźnie / Etnolingwistyka. 2002. №14; Bartmiński J., Panasiuk J. Stereotypy językowe / Współczesny język polski; red. J. Bartmiński. Lublin: UMCS, 2002. S. 374-378; Benedyktowicz Z. Portrety obcego. Od stereotypu do symbolu. Kraków, 2000.
} 
guidelines and socially predetermined priorities collective nationallanguage views and representations" ${ }^{\text {. }}$.

A similar opinion was followed by a Polish ethnographer J. St. Bystron and was expressed by Z. Benediktovich, who, in connection with the reconstruction of the "foreigner" image in the primitive and traditional folk culture, distinguishes such dichotomies as "human/inhuman", "human/ animal", "endowed with speech-mute, deaf", physical signs, smell, outward features/curvature, black complexion, communication of others as beings unclean with the other side, with the world of silence, darkness, death, etc ${ }^{9}$. Significant in this regard is the Belarusian folklore, according to which strangers were imagined as wild, naked, fur-covered people with tails who do not talk but squick while drinking the blood of their victims ${ }^{10}$.

The researcher in particular discusses the "humans/animals" opposition, which is in turn a manifestation of the "humans/nonhumans" opposition. The stranger was already represented in antiquity and the Middle Ages as half human and animal (donkey with horns, human with dog's head, human without head, with eyes on chest, one-eyed, with goat's hooves, or as a sleeping person for six months in winter). The juxtaposition of "those who have a language/dumb", which $\mathrm{Z}$. Benedictovich also explores in the framework of the "humans/nonhumans" opposition which is detyermined on the basis of popular culture and etymology in the word "German" (etymologically dumb, incomprehensible).

The aforementioned juxtapositions are closely related to the motive of strangers' belonging to lower mythology creatures. Polish ethnographer Jan St. Bystron in his work "Czarność obcych" emphasizes the attribution to aliens of supernatural features related to their appearance and physiology. The fact that a Lutheran, for example, has six toes is indicative. The researcher also admits the so-called internal "blackness". In Poland, there was a belief about the black palate of the Ruthenians, which testified their anger and emotion. The definition of "black" also applied to the Polish gentry ${ }^{11}$.

The characteristic feature of strangers as unclean creatures was the blindness of born children, which brought them closer to animals. The Poles called the blind the little Mazury children, who were credited with blindness at the baptism time. The mentioned researcher $\mathrm{Z}$. Benedictovich notes the existence of internal contradiction in the representation of the

\footnotetext{
${ }^{8}$ Воронін Д. І. «Ми» та «вони»: від моделі простору до моделювання соціокультурної взаємодії (на матеріалі російської мови) / Мовознавство, 2003. № 5. С. 54.

${ }^{9}$ Benedyktowicz Z. Portrety obcego. Od stereotypu do symbolu. Kraków, 2000. S. 121.

${ }^{10}$ Ibid.

${ }^{11}$ Bystroń J. S. Czarność obcych / Lud. T. 21. 1922. S. 180.
} 
image of another. On the one hand, strangers are considered to be soulless beings, restricted physically, distorted, wild, and on the other, associated with death, empty life, silence and darkness. A similar criterea is applied to language. The negative sign of silence and the inability to speak (deaf/mute) are contrasted with the positive - conversation, noise, voice as the natural language expression, which, in fact, analyzes the Nestor chronicle, said K. Moshinsky. These and similar ideas are embodied in Polish and Ukrainian proverbs and sayings. So, the expression ляхдевятьденник reflects the idea that the Poles are born blind, like kittens, and only on the ninth day do they have their eyes open. Compare the Polish proverbs Ślepy Mazur od ciemnej gwiazdy, Mazur się ślepo rodzi, Ślepy Mazur do dziewiętego dnia, ale jak przejrzy, to wszystkich oszuka, Mazur ślepo się rodzi, ale jak przejrzy, to przezę, to przezę ${ }^{12}$, Ukr. сліпий як мазур по полудні, Слипьй мазур за горами лупить козу пазурами ${ }^{13}$, Polish ethnographer O. Kohlberg in Kujawy recorded such humiliating mummies by Mazur Ty śleporod, ślepowron ${ }^{14}$; "When a Mazur is born, then for nine days he sees nothing and his mother holds him under a bowel $^{15}$, W mazurze taka dusa, choć umrze, to się rusa - similar contexts are attested in dialect dictionaries of Polish paremia ${ }^{16}$, U Mazura czarna rura (a teaser, which was addressed to the castors from Mazury and in response received: "Poty czarna ovi go Litwin $w$ dupe nie pocatuje") ${ }^{17}$. Even French engineer Guillaume de Boplan, in describing ancient Ukrainian customs and everyday life, drew attention to the belief in the puppy blindness of the Tatars for a long time after birth.

Perceptions of aliens for example Muscovites as cannibals, such creatures that eat carrion, raw meat of dogs, cats, frogs and other animals, are also common. All this again confirms the opinion that the alien was associated with animality, blackness, demonism, connected with trait and magic. For example, in Polish folklore, the devil was represented mostly in German attire. Polish ethnographer Ya. Bistron writes that Ukrainian peasants represented the devil in the form of a Polish nobleman ${ }^{18}$.

\footnotetext{
${ }^{12}$ Nowa księga przysłów i wyrażeń przysłowiowych polskich. T.1-4.Red. J.Krzyżanowski, S.Swirko. Warszawa: Państwowy Instytut Wydawniczy, 1969-1978. T. II. S. 420.

${ }^{13}$ Бессараба И.В. Матеріалы для этнографии Седлецкой губерніи. Санкт-Петербург, 1903. C. 84.

${ }^{14}$ Kolberg O. Lud, jego zwyczaje, sposób życia, mowa, podania, przysłowia, obrzędy, gusła, zabawy, pieśni, muzyka i tańce. Serya III. Kujawy. Cz.1. Warszawa, 1867. S. 120.

${ }_{15}$ Bajki,legendy i opowiadania ludowe, zebrane w pow.sokalskim / Lud. Kwartalnik etnograficzny. Rocznik IX. 1903. S. 67.

${ }^{16}$ Słownik gwar polskich. Ułożył Jan Karłowicz. Kraków 1903. T. 1-6. T. III. S. 131.

${ }^{17}$ Nowa księga przysłów i wyrażeń przysłowiowych polskich. T.1-4.Red. J.Krzyżanowski, S. Swirko. Warszawa: Państwowy Instytut Wydawniczy, 1969-1978. T. II. S. 418-419.

${ }^{18}$ Bystroń J.St. Megalomania narodowa. Warszawa: Lud, 1935. S. 264.
} 
In Eastern Slavic myths and legends, the peoples of distant, unknown lands were depicted as unattractive. So the Amazons seemed fantastic creatures with a dark angry face, armed with a spear and a bow with arrows, and the devian people (most likely, the inhabitants of India) appeared in the imagination of the Eastern Slavs as winged, multi-headed monsters with beastly or bird heads and feet. 1993, 9) ${ }^{19}$. Representatives of other nations acquired negative characteristics not only at the level of mythological but also naive embodiment of ethnic stereotypes: Ros. Немеччина, хитрая, безверная, басурманская, У франиуза ножки тоненьки, душа коротенька; the same is said of the German ${ }^{20}$, Грек скажет правду однажды в год, Татарин - свиное ухо (В.Даль), укр. Обідраний як швед тощо, Злодій на костилях, як лях в кайданах, Не дай, Боже, бугаями орати, а ляхами збірати, Польській міст, Лютерський піст, Турецььке набоженство -то все блазенство ${ }^{21}$; similar contexts are attested in the Belarusian linguoculture: Знаць ляха по холявах ${ }^{22}$, Грек за злато себе очи вылупит, Грек одну маслинку съест - и то пальчики обсосет ${ }^{23}$, Калмык - Иван иванович, маханник. Под собою кобылу съел, Калмык татарина маханиной (кониным мясом корит), Литвинь - земляники, землекопь, лопатники, Разве лихо возьмет литвина, чтоб он не дзекнул ${ }^{24}$, Belor. литвин як лин "is said about the Lithuanians who, under any business, slip up with cunning, like slippery flax" ${ }^{25}$, Литовский мост что немеикий пост is about something unimportant or incomprehensible ${ }^{26}$, Литва пошла (in Polissia dialects it is recorded as negligible) quarrels» ${ }^{27}$. In the "Great Dictionary of Russian Proverbs" the paremic contexts of other ethnic names, including ancient, ethnonym-related to Russians are repeatedly mentioned: Русь, руснак: Немец хитер: обезьяну выдумал, На всю Польшу один комар мозгу (глузду) принес, да и тот бабы расхватали,

${ }^{19}$ Голубовська І.О. Етнічні особливості мовних картин світу: Монографія, 2-е вид., випр. і доп. Київ, 2004. С. 37.

${ }^{20}$ В. М. Мокиенко, Т. Г. Никитина, Е. К. Николаева Большой словарь русских пословиц. Москва: Астрель, 2010. С. 592.

${ }^{21}$ Українські приказки, прислів'я і таке інше. Уклав М.Номис; упоряд., прим. М.М. Пазяка. Київ, 2004. С. 364.

${ }^{22}$ Сборник белорусских пословиц / Записки Императорского русского географического общества по отделению этнографии. Т.1. Санкт-Петербург 1867. С. 312.

${ }_{23}^{23}$ В. М. Мокиенко, Т. Г. Никитина, Е. К. Николаева Большой словарь русских пословиц. Москва: Астрель, 2010. С. 219.

${ }^{24}$ Ibid.

${ }^{25}$ Op. cit. C. 397, 486.

${ }^{26}$ Сборник белорусских пословиц / Записки Императорского русского географического общества по отделению этнографии. Т.1. Санкт-Петербург 1867. С. 337.

27 Українські приказки, прислів'я і таке інше. Уклав М. Номис; упоряд., прим. М.М. Пазяка. Київ, 2004. С. 838. 
Русак до читання, казак до спеванья, поляк до сказания, Русак задним умом крепок, Русак на трех сваях крепок: авось, небось да какнибудь, Русский глазам не верит - все надо помупать, Русский и с горя, и с радости пьет/поет, Что русскому здорово, то немиу смерть, У руським брюхи и тапор сгниет ${ }^{28}$. Let's compare some of the Polish probal formations that express character traits, psyches, preferences, attitudes to alcohol, work characteristic of different ethnicities, recorded in the compilation Nowa księga przysłów i wyrażeń przysłowiowych polskich (NKPPie) «Nowa księga przystów $i$ wyrażeń przysłowiowych polskich» (NKPP): Kto wegierskie pije po śmierci nie gnije [NKPP III: 646], Gdzie Węgier, tam gniew, gdzie Stowak tam śpiew [NKPP III: 646], Polak, Wegier dwa bratanki $i$ do szabli $i$ do szklanki [NKPP III: 646], Tłucz Węrzyna w moździerzu, przecie on będzie czosnkiem śmierdziat po staremu [NKPP III: 646], Namaż ty Ruska masłem, przecież on dziegciem śmierdzi [NKPP III: 101], Rusek do czytania, Chochlak do śpiewania, Polak do opowiadania [NKPP III: 101]. The connection of aliens with mythological creatures and their similarity to them is evidenced by the following Ukrainian paremie contexts, recorded in M. Nomys's Collection: Вражі (або: чортові) Ляхи, Що чорт, щзо Жид, то рідниі брати, Коли чорт та москаль щзо вкрали, то поминай, як звали, Москаль як ворона, та хитріший чорта ${ }^{29}$.

\section{Stereotypical ideas about collective groups, local and religious names of Slavs}

In his work «Megalomania narodowa», Polish ethnographer J. Bistron explains the means of naming tribal and local groups from the point of view of ethnic and cultural contacts. They are micro-ethnonyms (ethnic names), where the object of the name is the residents of the neighboring border areas, which reflect the traditional ideas of strangers and aliens. The mechanism of the emergence and comprehension of experiences about these collective groups objectifies the "re-evaluation of oneself", reflects the evaluative idealization of their group, leads to collective and social megalomania, which was peculiar to the primitive peoples and by which this, external, world, can be influenced by a certain system of ritual actions. The claim of others reflects collective social and cultural values, and the alien image set of traits identification is essential for the study of the rejection or hatred psychology of certain tribes and groups in

\footnotetext{
${ }^{28}$ Смоленский этнографический сборник. Сост. В.Н. Добровольский. Ч. ІІІ. Пословицы. Санкт-Петербург, 1894. С. 81.

29 Українські приказки, прислів'я і таке інше. Уклав М.Номис; упоряд., прим. М.М. Пазяка. Київ, 2004. С.838.
} 
traditional folk culture, which, in modern studies, finds its continuation in the theory of ethno-stereotypes. "The nickname is often encountered in the different ethnocultural groups," says J. Bystron, "for example, it concerns the environment of Polish immigrants in America, in which immigrants are referred to as indigenous people, in particular, pyrky (residents of Poznan), pyry. "Potatoes") ${ }^{30}$.

As the Russian researcher A. Zhuravlev rightly points out, local-group names contain different features in their appearance, in particular the designation of the location in which the carriers of the nickname reside, its natural-geographical landscape, the characteristic natural conditions; such micro-ethnonyms can objectify real historical events (migration processes, local history, residents' contacts with a particular ethnic group); anecdotal nature events, facts and stories that make fun of something different, other traits of occupations, crafts, material culture, cuisine, clothing and shoes type, the manner of their wearing and use, etc ${ }^{31}$.

In general, the stereotype (from the Greek. Stereos - solid and topos imprint, sample) - «word, linguistic recurrence, unchanged, as the established formula, language pattern".

Ethnologists refer to ethnic stereotypes as "cultural standards, stamps, and behavioral skills that, through transgenerational communication, have shaped the unique face of ethnic groups in the course of ethnogenesis and adaptation to the environment"32. W. Lippman, who introduced this concept into cognitive linguistics, views the stereotype as a one-sided, partial and simplified image in the human head, a common mental correlate of objects and phenomena of the world. This sociological approach emphasizes the social aspect of stereotypes, that is, their formation and function in social behavior.

Polish researcher K. Pisarkova points to differences in the evaluation of the auto-stereotype (imaginative ideas about one's ethnicity) and the stereotype of someone else. This is especially the case in the selfidentification of the ethnic stereotypes bearer, which emphasizes the positive evaluation of one's social group and the negative evaluation of another ethnic group representatives ${ }^{33}$. The Polish ethnographer A. Kempinski sees the reason for the others interest and the stereotypes formation "by the hidden thirst of this people to increase their own internal ethnos value sense" ${ }^{34}$.

\footnotetext{
${ }^{30}$ Bystroń J.St. Megalomania narodowa. Warszawa: Lud, 1935. S. 75.

${ }^{31}$ Васильев M.А. Анты, словене, немцы, греки: славянский культурно-лингвистический мир и его соседи в раннесредневековое время / Славяноведение. 2005. № 2. С. 14.

32 Тиводар М. Етнологія. Львів, 2004. С. 154.

${ }^{33}$ Pisarkowa K. Tożsamość nosiciela stereotypów etnicznych / Etnolingwistyka, 2002. № 14. S. 27.

${ }^{34}$ Kępiński A. Lach i Moskal. Z dziejów stereotypu. Warszawa - Kraków, 1990. S. 7.
} 
The stereotype is also the object of studies of ethno-linguists (E. Bartminsky, I. Lappo, U. Mayer-Baranovska, J. Panasyuk), who primarily interpret it not as words (as in common dictionaries) or as corresponding to real objects (as in encyclopedias) but as a kind of semantic correlates that stand between words and objects, otherwise public perceptions of the subject. Under the stereotype, which inherits a narrower understanding of the formula, Polish linguists understand the idea of an object that is framed in a certain social frame and determine, "what that object is, how it looks, how it is interpreted by a person, etc., such an idea is embedded in the language and is accessible through language and pertaining to collective world knowledge". E. Bartminsky mentions of stereotypes as "stabilized in culture and language characteristics that correlate with the name of objects". Another definition, which is practically embodied in the concept of stereotypes and cultural symbols of the Lublin ethno-linguistic school, is "a subjectively conditioned view of a something which descriptive and evaluative features exist and which results from the reality interpretation within socially produced models ..."; its aim is to reproduce "a cultural-linguistic portrait of the object being described and to show how it is viewed by a typical cultural representative" ${ }^{35}$.

According to Jerzy Bartminski, "in sociology, stereotypes are "notorious", they are biased by the tendency of evaluation, mass consciousness manipulation, which for the most part becomes a barrier in human and intercultural communication. However, in linguistics, stereotypes is a cognitive, culturally reconstructive category, aimed at the categorization of the object, because the language not only gives a negative assessment to someone (mother-in-law, stepmother) or for some reason, also simplifies, generalizes and symbolizes ${ }^{36}$.

The stereotyping of representations in individual, everyday consciousness identifies "one's own" either with an emotionally neutral norm or with a positive evaluation. For the most part, "alien" is rated neutral or negative. When referring to external ethnonymics (naming by someone) it should be noted that the means of nomination are based on the external name characteristic or subjective assessment of ethnicity, its way of life, social or political system, historical and spiritual development. Such "external ethnonyms are used by hostile communities and have disapproving characteristics, often offensive. This type of ethnic

35 Толстая С.М. Этнолингвистика Ежи Бартминьского / Языковой образ мира: очерки по этнолингвистике. Москва: Индрик, 2005. С. 16.

${ }^{36}$ Bartmiński J. Stereotypy mieszkają w języku. Studia etnolingwistyczne Lublin: UMCS, 2007. S. 8. 
nomination is highlighting and sharply contrasting to certain, not always clear or unusual, signs and brings such names closer to abusive nicknames or even invectives" ${ }^{37}$.

Let us consider these linguistic facts on the basis of ancient Slavic ethnographic sources.

As the ethnographer I. Bessaraba states in the Siedlec province, they say "Поляк зъйів... гною за трояк"; the historical confrontation between the Masurians and the Rusyns is attested in the following contexts: "Mazur: Rusin kobyte zadusit - Mazur: Rusyn strangled the mare, Rusyn: A polacy się zbiegli i kobyłe zjedli - A поляки позбігались і їі з 'їли» ${ }^{38}$.

In Polish ethnographic works of XIX - XX century. O. Kolberg, A. Fisher, E. Rulikovsky and others such ethnic surnames of Ukrainians (Ruthenians) were recorded as барани, чуби, чубарики, хештаки, секали, постольники ${ }^{39}$. For example, the Russian gurals wore the nickname цүотаки (they say цоо таке, sotaki), лішаки, lishaks (use lisz in the meaning of "only"; Bukovynian Hutsuls are called баранами (rams), because there peasants wear beards once гештаками Polishchuk (from exclamation when referring to "Heshta" horses; in the Kholm region, синіï латки the Russian people call the Mazur постольниками ${ }^{40}$.

Russian ethnographers D. K. Zelenin, I. Snegirev call these collective nicknames and ethnic nicknames "folk sayings." They do not refer to a single person, but to a group of persons that is a geographical or ethnographic entity; in these units, "the people submit an ethnographic division of themselves" ${ }^{41}$. D. Zelenin considers nicknames of this type an important element for the study of folk poetry, folklore, book writing, cultural history of the ethnic group and its relations with neighbors and in general for the comparative characterization of different ethnographic groups. This unit from a linguistic point of view can be expressed by a single-word name, phrase or whole sentence, dialogue, anecdote ${ }^{42}$.

An example of such regional collective-regional designations is ridicule, mockery of certain people communities, for example, in the Russian areal space: Андозера-хайдуки - нет ни хлеба, ни муки

\footnotetext{
37 Левицький А.Е., Святюк Ю.В. Етнономінації у дзеркалі міжкультурної комунікації. Монографія. Київ, 2011. С. 29.

38 Бессараба И.В. Матеріалы для этнографии Седлецкой губерніи. Санкт-Петербург, 1903. C. 84.

${ }^{39}$ Rulikowski E. Zapiski etnograficzne z Ukrainy / Zbiór wiadomości do antropologii krajowej. T. III. Kraków, 1879. S. 129.

${ }^{40}$ Fisher A. Rusini. Zarys etnografii Rusi. Lwów-Warszawa-Kraków, 1928. S. 8.

41 Зеленин Д.К. Великорусские народные присловья как материал для этнографии / Избранные труды. Статьи по духовной культуре 1901-1913. Москва: Индрик, 1994. С. 51.

${ }^{42}$ Ibid. C. 39.
} 
(Andozera - residents of Andozerskoye village) - mock at the fact that they have little activity and eat only fish from their lake ${ }^{43}$, горчичник - so once were called the inhabitants of Samara (sown a lot of mustard), гужатники (boiled crows instead of mushrooms), гужееды - immigrants from different provinces of Russia; they were very poor, and from hunger were forced to eat the harnesses from the harness ${ }^{44}$, the кереметники the nickname of the Marians (from the кереметка - a nervous disease, similar to epilepsy) ${ }^{45}$, гущча новгородская ${ }^{46}$, Даниловиьы и романовиы барана в зыбке закачали ${ }^{47}$, Егорьевцьь - коноваль, головотяпь, рудометь,${ }^{48}$ Калязинцьь - свинью за бобра купили; собаку за вола купили, Тверитяне вприглядку с сахаром чай пьют ${ }^{49}$. In the Ukrainian ethnoculture, there are different toponymic nicknames, characterized by M. Nomis: В Суражі все люди вражі, В Олику - полика, в Клевань - по діда, в Дражню -по горики (the first two towns, and then - the village in Volyn, ) Ромен город на горі, по дві дурнииі на дворі - thanked Romnov visiting fair visitors, 3 Вересочі повилазили очі, Поніриі - дурні вівиі, Dive - silly sheep, Krasnyane (Krasnokolyadinka), народ хитруватий и рощзотний, ridicule so from Poniortsi (village Ponyra) ${ }^{50}$.

The Belarussian folk-dialect language presents some collective-group names for designation of preferences, occupations' nature of, historicalcultural, natural-geographical features of Byelorussian inhabitants, crafts characteristics and so on: Могилевцы-кулажники кулагу на локоць продаюиь, а на палец прибавки дають - насмешка над уроженцами города Могилева и даже могилевской губернии ${ }^{51}$, Мсцичлавиьь не умирають на своей лавце - характеризует природных Мстиславских жителей, мещуан, не любящих сидеть дома ${ }^{52}$, Оршаниь-вапенникинасмешливое название жителей города Орши, где в большом количестве находят известковый камень ${ }^{53}$.

${ }^{43}$ В. М. Мокиенко, Т. Г. Никитина, Е. К. Николаева Большой словарь русских пословиц. Москва: Астрель, 2010. С. 43.

44 Словарь русских народных говоров. Вып.1-36. Москва-Ленинград (СПб.): Наука, 1965-2002. Вып.8. С. 204-205.

${ }^{45}$ Ibid. Вып.13. C. 186.

${ }^{46}$ Ibid. Вып.8. C. 251.

${ }^{47}$ В. М. Мокиенко, Т. Г. Никитина, Е. К. Николаева Большой словарь русских пословиц. Москва: Астрель, 2010. С. 233.

${ }^{48}$ Ibid. C. 325.

${ }^{49}$ Ibid. C. 397, 900.

${ }^{50}$ Українські приказки, прислів‘я і таке інше. Уклав М.Номис; упоряд., прим. М.М.Пазяка. Київ, 2004. С. 585

${ }^{51}$ Сборник белорусских пословиц / Записки Императорского русского географического общества по отделению этнографии. Т. 1. Санкт-Петербург, 1867. С. 344.

${ }^{52}$ Ibid. C. 346.

${ }^{53}$ Ibid. C. 392. 
In another ethnographic source, "Smolensk Ethnographic Collection" recorded many Belarusian and Russian ottonymic names, often with emotionally-expressive, disparagingly-offensive and mockingly-ironic connotation designating the intellectual abilities of man, his exterior. For example, арлоуцьы - прабитая голова, Смаленьщина - шабашники, ражком сабор падперли; рязанщы телку огуриом резали; калужиы на аршин квас прадают; самариы на меру кишки прадають, аржаўцы (Ельниниьь) аглоблю абпалюють и ездють в пабирашки ${ }^{54}$.

\section{CONCLUSIONS}

Thus, the article examines some mechanisms of nominative identification (lexical, figurative, folklore) of ethnic nominations, individual religious stereotypes and ethnic names of Ukrainians, Russians, Byelorussians and Poles. Some of them clearly reflect the ancient ethno and cultural stereotypes (ritual, custom, mythological) associated with the idea of foreigners against the ethnic groups image background. The semantics and pragmatics of these names, as we have seen, are caused by stereotypical attitudes towards a certain ethnicity, the principle of ethnocentrism, uniqueness, isolation, exclusiveness of "one's own" and negative attitude to "alien", different names of neighboring local groups, especially at the linguistic and cultural border. Evidence of this is considered by some ethnic and local-group (collective-regional), including toponymic surnames, nicknames and unofficial surnames of the characterevaluative type.

It interesting to discuss collective-regional and ethnic nicknames nomination models of reflected in the precedent texts (anecdotes, artistic, folklore, including ritual texts of different genres). One can speak separately about the ethnonyms functioning in various ritual practices, orders, omens, folk beliefs, ritual games, calendar ceremonies, riddles, and not only Slavic ones. For example, in the well-known collection of English puzzles abount the world's background and especially we can find ethnonyms in the European, Eastern and some exotic peoples riddles about the pot and other household items and plants. In these enigmatic texts, the ethno-racial plan is combined with the symbolism of the parts of the human body names, which is first and foremost related to the anthropomorphic character of many ancient everyday artifacts of material culture and instruments symbolism, such as spindles, coffers, sieves, etc. For example, a black man and a tan are identified through clothing

\footnotetext{
${ }^{54}$ Смоленский этнографический сборник. Сост. В.Н.Добровольский. Ч. ІІІ. Пословицы. Санкт-Петербург, 1894. С. 96.
} 
(wearing brown trousers) or a horse's color: A Negro in brown breeches on a brown horse, carrying a black pot on his head ${ }^{55}$. Even more striking are the riddles texts with a another nation representative, a Russian whose hair is sticking out of a pot, designates the radish that protrudes from the ground (this puzzle has several variants): A Russian in a pot, his hair sticks out.-Radish; White Russian in the bathhouse, his beard outside. Radish), Next to the bathhouse lies a White Russian, and his beard shines outside. - Radish), My grandfather's body is in Hades, his beard is in the world. Now, explain. - Radish) ${ }^{56}$, Stiff standing in the bed, / Sometimes white and sometimes red, / Every lady in the land / Takes it in her hand, I And puts it in the hole before. - Radish.

Polish erotic sexual riddles imitate sexual intercourse when the pot boils, which is codified by the ethnic names of gypsies: Siedzi Cygan na Cygance, poty nie zlezie, az się osmarce. - Pot with boiling water; other things in household use include the image of the Tartar: Szukój w polu Tatarzyna, and Tatarzyn za teb trzyma. Leno czasem dobry klaps, ni ma z niego ani chaps; The German functions in the riddle about the beet: Siedzi Niemiec w ziemi, teb mu sie zieleni, and the German woman is onion, cf. Przyjechała Niemka $w$ czerwonych sukienkach. - Jak ja rozbierali, to nad nia ptakali; this is not something to complain about; instead, the Hungarians codify the image of a cat: Chodzit Wegier po wegrzynie, nosieł dzieci w koszałczynie. Które wrzaśnie, to przyklaśnie, które piśnie, to przyciśnie ${ }^{57}$.

It should be noted that in other Slavic languages, the Gypsy ethnonym implements another structural-semantic adverb 'do unnecessary vain' proverbs, as evidenced by the contexts in one of V. Fleischans' most ancient Czech phraseology: cikána. - literally: "wash the gypsy» ${ }^{58}$. And in English, the phrase with the Gypsy component to indicate the variety of the dish is certified: Gypsy stews the rabbit Dish with onions and potatoes (so-called because the main ingredients are readily available to gypsies) ${ }^{59}$.

The proposed article does not claim to be a comprehensive description of such ethnic names, but outlines possible ways of studying archaic ethnonominations and some religious, confessional designations in the

${ }^{55}$ Taylor A. English Riddles from Oral Tradition / A. Taylor. - Berkeley and Los Angeles, 1951. P. 34.

${ }^{56}$ Op. cit. P. 196, 638.

${ }^{57}$ Polskie zagadki ludowe. Wybrał i opracował S.Folfasiński. Warszawa: Ludowa Spółdzielnia Wydawnicza, 1975. S. 146-147.

${ }^{58}$ Česka přislovi. Sbirka přislovi, prupovedi lidu českeho v cechach, na Morave a v Slezsku /vybral a uspořadal V.Flajhans, D. 1-2, Praha: Nakladem F.Simacka 1911-1913. D. 1. S. 68.

${ }^{59}$ Wilkinson P.R. A Thesaurus of Traditional English Metaphors / P. R. Wilkinson. London ; New York : Routledge, 1993. P. 13. 
Slavic linguistic space by lexicographic and ethnographic data, and the possibility of comparing them with other languages.

\section{SUMMARY}

The article deals with some mechanisms of ethnic nominations nominative identification (lexical, figurative, folklore), individual religious stereotypes and ethnic names of Ukrainians, Russians, Byelorussians and Poles. Some of them clearly reflect the ancient ethno - and cultural stereotypes (ritual, custom, mythological) associated with the idea of foreigners with the background image of other ethnic groups. The semantics and pragmatics of these names, as we have seen, are conditioned by stereotypical attitudes towards a certain ethnicity, the principle of ethnocentrism, uniqueness, isolation, exclusiveness of "one's own" and negative attitude to "alien", the names of neighboring local groups. This is evidenced by some ethnic and local-group (collectiveregional) considerations, including toponymic surnames and nicknames.

Ethnonyms are spoken in comparable languages not only as a part of stable words compounds, but also reflected in folklore pragmatics - verbal magic, healing magical practice, texts of orders, dream books, different in intensity verbal speech acts-wishes and, of course, in rhytal, as a broader semiotic embodiment of the manifestos of one's own and others' space.

It is promising to cover nomination models for collective-regional local nicknames that are related to foreign or neighboring regional groups representatives. The proposed article does not claim to be a comprehensive description of such ethnic names, but outlines possible ways of studying archaic nicknames. The latter constitute a significant part of the archaic ethnonymicone and toponymicone, which is promising for consideration in areal-typological, onomassiological and cognitive-pragmatic terms.

At present, models of nomination for collective-regional and ethnic nicknames are reflected in the precedent texts (anecdotes, artistic, folk, including ritual texts of different genres).

\section{REFERENCES}

1. Белова О.В. Этнокультурные стереотипы в славянской народной традиции / О.В. Белова. М.: Индрик, 2005. 288 с.

2. Бессараба И.В. Матеріалы для этнографии Седлецкой губерніи.-СПб.: Тип. Имп. Акад. наук, 1903. 324 с.

3. Васильев М.А. Анты, словене, немцы, греки: славянский культурно-лингвистический мир и его соседи в раннесредневековое время / М.А.Васильев // Славяноведение. 2005. № 2. С. 3-17. 
4. Воронін Д. І. «Ми» та «вони»: від моделі простору до моделювання соціокультурної взаємодії (на матеріалі російської мови) / Д.І.Воронін // Мовознавство. 2003. № 5. С. 50-56.

5. Голикова Т.А. Стереотип как этнически и культурологически обусловленный компонент менталитета / Т.А. Голикова // Мир языка и межкультурная коммуникация / отв. ред.. Э.Е. Курлянд. Ч. 1. Барнаул: БГПУ, 2001. С. 80-87.

6. Голубовська I.О. Етнічні особливості мовних картин світу: Монографія, 2-е вид., випр. і доп. / I.О. Голубовська. К.: Логос, 2004. $284 \mathrm{c}$.

7. Даль В.И. Толковый словарь живого великорусского языка в 4-х томах. М., 1989-1991. Т. 1-4.

8. Добровольский В.Н. Смоленский этнографический сборник. Ч. 1-4. СПб., М. 1891-1903.

9. Зеленин Д.К. Великорусские народные присловья как материал для этнографии / Д.К. Зеленин // Избранные труды. Статьи по духовной культуре 1901-1913. М.: Индрик, 1994. С. 38-58.

10.Куликовский Г. Словарь областного олонецкого наречия в его бытовом и этнографическом применении. Санкт-Петербург.18981999.

11.Левицький А.Е., Святюк Ю.В. Етнономінації у дзеркалі міжкультурної комунікації. Монографія. / А.Е. Левицький, Ю.В. Святюк. К.: Логос, 2011. 192 с.

12. Мокиенко В., Никитина Т., Николаева Е.К. Большой словарь русских пословиц. Москва: Олма Медиа Групп, 2010. 1024 с.

13. Мокиенко В.М, Николаева Т.Г. Большой словарь русских поговорок. Москва: Олма Медиа Групп, 2007. 784 с.

14.Номис М. Українські приказки, прислів'я і таке інше. Київ: Либідь, 2004. 768 с.

15.Пастернак Я. Звичаї та вірування в с.Зіболках Жовківського повіту / Я. Пастернак // Матеріали до етнології й антропології. Т. XXI-XXII. Ч. 1. Львів, 1929. С. 321-352.

16.Подвысоцкий А.А. Словарь областного архангельского наречия в его бытовом и этнографическом применении. СПб.: 2-е Отд-ние Акад. наук, 1885. 198 с.

17.Пономарьов А. Українська етнографія. Курс лекцій / А.Пономарьов. Київ: Либідь, 1994. 317 с.

18. Русские крестьяне. Жизнь. Быт. Нравы. Материалы «Этнографического бюро» князя В.Н. Тенишева.-Том 1. Калужская губерния. Спб., 2004. 568 с. 
19.Русские крестьяне. Жизнь. Быт. Нравы. Материалы «Этнографического бюро» князя В.Н. Тенишева.- Том 1. Костромская и Тверская губернии. Спб., 2004. 570 с.

20.Сборник белорусских пословиц // Записки Императорского русского географического общества по отделению этнографии. Т. 1. Санкт-Петербург 1867. С. 255-482.

21. Словарь русских народных говоров. Вып. 1-36. МоскваЛенинград (СПб.). 1965-2002.

22. Тиводар М. Етнологія / М. Тиводар. Львів: Світ, 2004. 621 с.

23. Толстая С.M. Этнолингвистика Ежи Бартминьского / С.М. Толстая // Языковой образ мира: очерки по этнолингвистике. М.: Индрик, 2005. С. 9-20.

24. Bajki, legendy i opowiadania ludowe, zebrane w pow.sokalskim // Lud. R.IX. 1903. S. 67-68.

25. Bartmiński J. Stereotypy mieszkają w języku. Studia etnolingwistyczne / J. Bartmiński. Lublin: UMCS, 2007. 360 s.

26. Bartmiński J., Lappo I., Majer-Baranowska U. Stereotyp Rosjanina i jego profilowanie we współczesnej polszczyźnie // Etnolingwistyka. 2002. № 14. S. 105-152.

27.Bartmiński J., Panasiuk J. Stereotypy językowe / J. Bartmiński, J. Panasiuk // Współczesny język polski, red. J. Bartmiński, Lublin: UMCS, 2002. S. 374-378.

28. Benedyktowicz Z. Portrety obcego. Od stereotypu do symbolu / Z. Benedyktowicz. Kraków, 2000. 216 s.

29. Bystroń J. S. Czarność obcych / J.S. Bystroń // Lud. T. 21.1922. S. $179-182$.

30.Bystroń J.St. Megalomania narodowa / J.S. Bystroń. Warszawa: Lud, 1935. $244 \mathrm{~s}$.

31.Česka přislovi. Sbirka přislovi, prupovedi lidu českeho v cechach, na Morave a v Slezsku / vybral a uspořadal V. Flajhans, D. 1-2, Praha: Nakladem F.Simacka 1911-1913.

32. Federowski M. Lud okolic Żarek, Siewierza i Pilicy, jego zwyczaje,sposób życia, obrzędy, podania, gusła, zabobony i tp. Warszawa, 1889. 345 c.

33. Fisher A. Rusini. Zarys etnografii Rusi / A. Fisher. LwówWarszawa-Kraków, 1928.

34. Kępiński A. Lach i Moskal. Z dziejów stereotypu / A. Kępiński. Warszawa - Kraków, 1990. S. 57.

35. Kolberg O. Lud, jego zwyczaje, sposób życia, mowa, podania, przysłowia, obrzędy, gusła, zabawy, pieśni, muzyka i tańce. Serya III. Kujawy. Cz. 1. Warszawa, 1867. 
36. Nowa księga przysłów i wyrażeń przysłowiowych polskich. T. 1-4. Red. J. Krzyżanowski, S. Swirko. Warszawa, 1969-1978.

37.Petrow A. Lud ziemi Dobrzyńskiej, jego charakter, mowa, zwyczaje, obrzędy, pieśni, przysłowia / A. Petrow // Zbiór wiadomości do antropologii krajowej. T. II. Kraków, 1878. S. 15-40.

38. Pisarkowa K. Tożsamość nosiciela stereotypów etnicznych / K. Pisarkowa // Etnolingwistyka, 2002. № 14. S. 27-45.

39.Polskie zagadki ludowe. Wybrał i opracował S.Folfasiński. Warszawa: Ludowa Spółdzielnia Wydawnicza, 1975. 455 s.

40. Rulikowski E. Zapiski etnograficzne z Ukrainy / E. Rulikowski // Zbiór wiadomości do antropologii krajowej. T. III. Kraków, 1879. S. 62-167.

41.Słownik gwar polskich, ułożył Jan Karłowicz. Kraków, 1903. T. 1-6.

42. Taylor A. English Riddles from Oral Tradition / A. Taylor. Berkeley and Los Angeles, 1951. 959 p.

43. Wilkinson P.R. A thesaurus of traditional English metaphors / P. R. Wilkinson. London ; New York : Routledge, 1993. 490 p.

\section{Information about the author:} Tyshchenko O. V.,

Doctor of Philology, Professor at the Department of Foreign Languages and Translation Studies,

Lviv State University of Life Safety 35, Kleparivska str., Lviv, 79007, Ukraine, Professor at the Department of Russian Studies, University of Ss. Cyril and Methodius in Trnava nam. Herdu 2, Trnava, Slovak Republic 


\section{THEOLOGICAL TERMS IN GERMAN: GENERAL OVERVIEW}

\section{Veresh M. T.}

\section{INTRODUCTION}

The terminological systems of different languages for Special Purposes (LSP) in today's multicultural and globalized world are becoming increasingly important, since communication in the professional field requires thorough knowledge of not only the field itself, but also the means of its expressing. The term as a unit of a particular terminological system is a tool for professional communication. The term Christian-theological terminological system clearly defines the sphere of functioning - units that define concepts and phenomena in the field of theology as the doctrine of God and the Word of God based on Revelation.

The historical events of the 1990s, the legalization of the Catholic Church in the post-Soviet space contributed to the growth and spread of spirituality and made it possible to activate the church's public activities. At the same time, the process of introducing the discipline of "theology" at the state level was intensified.

\section{Theology as a science. Theological terms from the linguistic point of view. Languages for special purposes (LSP)}

In Christian world, the term theology is the doctrine of God based on Revelation, that is, the methodical attempt to understand and explain the Divine Revelation of truth ${ }^{1}$. This "Revelation is contained in the Holy Tradition and the Holy Scriptures of the Old and New Testaments and is entrusted to the Holy Church. The pinnacle of Divine Revelation is the incarnate of the Holy Spirit and Mary the Virgin, the Son of God - Jesus Christ, who in his words and deeds declared the love of God the Father"2. In our opinion, this aspect should be emphasized.

Theology is a scientific teaching in which "the Christian mind is confident and enlightened by the light of faith. It seeks by thought to understand what it believes in. The object of faith is the revealed

\footnotetext{
${ }^{1}$ Католическая Энциклопедия в 5-ти томах. - М. : Издательство Францисканцев, 2002. - T. 1. - С. 631.

${ }^{2}$ Катехизм Української Греко-Католицької Церкви : Христос - наша Пасха. - Львів : Свічадо, 2011. - С. 19.
} 
sacrament. Being aware of it, one realizes many consequences that follow from it" ${ }^{3}$. St. Thomas Aquinas thus covers the emergence of theology as a science: "It was necessary for man's salvation that there should be a knowledge revealed by God besides philosophical science built up by human reason. Firstly, indeed, because man is directed to God, as to an end that surpasses the grasp of his reason: "The eye hath not seen, O God, besides Thee, what things Thou hast prepared for them that wait for Thee" (Is. 66:4). But the end must first be known by men who are to direct their thoughts and actions to the end. Hence it was necessary for the salvation of man that certain truths which exceed human reason should be made known to him by divine revelation. Even as regards those truths about God which human reason could have discovered, it was necessary that man should be taught by a divine revelation; because the truth about God such as reason could discover, would only be known by a few, and that after a long time, and with the admixture of many errors. Whereas man's whole salvation, which is in God, depends upon the knowledge of this truth. Therefore, in order that the salvation of men might be brought about more fitly and more surely, it was necessary that they should be taught divine truths by divine revelation. It was therefore necessary that besides philosophical science built up by reason, there should be a sacred science learned through revelation"4.

The term "bohoslovya" in the Ukrainian language is synonymous with the terminological unit "heology", which is used in many languages, derived from the Greek words: $\lambda o ́ \gamma o \varsigma$ - word, concept, doctrine, and $\theta \varepsilon o ́ \varsigma$ God. $\theta \varepsilon o \lambda$ oyi $\alpha$ - the doctrine of God, theology (or as it can also be called in Ukrainian “богослов'я", i. e. "bohoslovya”) ${ }^{5}$. We should point out that the term "bohoslovya" derives from two words: Boh - God and slovo word, concept, doctrine. Thus, one can easily see that both terms point to the same reality. However, in certain circles there is a tendency to supplant the assimilated Church Slavonicism "bohoslovya" with the new Greek word "theology". Authors who use the term "bohoslovya" generally focus on Eastern Christian tradition, while those who use the term "theology" focus on Western Christian ones ${ }^{6}$.

\footnotetext{
${ }^{3}$ Стасяк С.-Я. Основи догматичного богослов'я / о. С.-Я. Стасяк, о. Р. Завіла. - Львів : Мiсіонер, 1997. - C.5

${ }^{4}$ St. Thomas Aquinas : [Електронний ресурс]. - Режим доступу : https://dhspriory.org/ thomas/summa/FP/FP001.html\#FPQ1OUTP1

${ }^{5}$ Греческо-русский словарь / [под ред. А.Д. Вейсмана]. - С. Петербург, 1899. - С. 601.

${ }^{6}$ Термінологічно-правописний порадник для богословів та редакторів богословських текстів. - Львів, вид. Інституту богословської термінології та перекладів Українського Католицького Університету, 2005. - С. 26.
} 
Early Christian apologists, namely Origen and Eusebius of Caesarea, first used the terminological unit "theology" . According to Origen, theology is the doctrine of God, in a special way about the Savior Jesus Christ. So, doing theology means acknowledging and praising God in Christ. <...> Theology also researches The Word of God, which the scholar (theologian) seeks to properly perceive and interpret, the faith and its effect on man and society (dogmatic and moral theology), Jesus Christ (Christology), man (theological anthropology) ${ }^{8}$.

When considering the terms of the Christian-theological terminological system, one should understand the concept of theology in the light of Catholic teaching, since it is interpreted differently. The Catechism of the Catholic Faith provides the following explanation: "The Fathers of the Church distinguish between theology (theologia) and economy (oikonomia). Theology refers to the mystery of God's inmost life within the Blessed Trinity and economy to all the works by which God reveals himself and communicates his life. Through the oikonomia the theologia is revealed to us; but conversely, the theologia illuminates the whole oikonomia. God's works reveal who he is in himself; the mystery of his inmost being enlightens our understanding of all his works" $"$.

With the emergence of the first universities in the $12^{\text {th }}$ century, including Bologna in 1088 and Paris in 1215, the sacred doctrine began to be called theology. Great credit goes to Pierre Abelard, a French philosopher and theologian who introduced the term "theology" in the title of his scholarly work "Theologia christiana" (Christian theology) ${ }^{10}$ [87, p. 632]. The term "theology" (Theologie) in German is a borrowing from the Greek language and dates from the $15^{\text {th }}$ century. It denotes the doctrine of God and His revelation, as well as the faith and essence of the church ${ }^{11}$.

Theology as a science has formed certain special disciplines in the course of historical development : ascetic (spiritual) theology, moral, fundamental, dogmatic and biblical theology, the theology of the Fathers of the Church, catechetic, homiletics, pastoral theology, liturgical and canon law ${ }^{12}$, each containing the relevant lexical units.

\footnotetext{
${ }^{7}$ Стасяк С.-Я. Основи догматичного богослов'я / о. С.-Я. Стасяк, о. Р. Завіла. - Львів : Місіонер, 1997. - С. 5.

8 Католическая Энциклопедия в 5-ти томах. - М. : Издательство Францисканцев, 2002. - T. 1. - C. 632.

${ }^{9}$ Catechism of the Catholic Church : [Електронний ресурс]. - Режим доступу : http://www.vatican.va/archive/ENG0015/_P17.HTM\#7X.

${ }^{10}$ Католическая Энциклопедия в 5-ти томах. - М. : Издательство Францисканцев, 2002. - T. 1. - C. 632.

${ }^{11}$ Duden, Etymologie : Herkunftswörterbuch der deutschen Sprache / [bearb. von G. Drosdowski]. - Mannheim, Leipzig, Wien, Zürich : Dudenverlag, 1997. - S. 743.

12 Обер о. Ж.-М. Моральне богослов'я / о. Жан-Марі Обер : [переклад 3 італ. о. д-ра М. І. Любачівського] : [2-ге вид, виправ.]. - Львів : Стрім, 1997. - С. 8-10.
} 
The concepts of "Languages for Special Purposes" (LSP) and "terminological system" in linguistics are interrelated. In order to clarify the relationship between these concepts, it is necessary to dwell on their definitions. According to L. Hoffmann, "LSP is the unity of all linguistic means used in the professionally limited communication field to ensure understanding between individuals in a particular field of activity"13. Languages for Special Purposes are also "means of optimal understanding of the subject area for professionals. They are characterized by a specific vocabulary and special rules for the choice, use and frequency of commonly used lexical and grammatical means. They do not exist as an independent form of realization in language, but is actualized in professional tests, which, in addition to the elements of the professional text, always contain elements of the common language” ${ }^{\text {"14 }}$. Languages for Special Purposes are "a set of all language means used in a professionally closed field of communication to ensure mutual understanding between people working in this field" 15 . "Languages for Special Purposes are means of cognition and conceptual definition of a specific reality of the profession, as well as a means of mutual understanding in the field, and thus takes into account the specific needs of communication within the profession" ${ }^{\text {" }}$.

Although there is no clear definition of the term "Languages for Special Purposes", the definitions of the term "LSP” given here make it possible to distinguish their main task, "which is to create accurate and economical meaningful tools for understanding the subject area or field of activity and serve mainly to meet the needs of professional communication" ${ }^{17}$. According to L. Hoffmann, professional communication is an externally or internally motivated or stimulated external and internal system of knowledge aimed at a chain of professional events that change the knowledge system of both one specialist and a group of specialists $^{18}$. Three concepts proposed by $\mathrm{T}$. Roelcke became the basis

${ }^{13}$ Hoffmann L. Kommunikationsmittel Fachsprache / L. Hoffmann // Forum für FachsprachenForschung. - [2., völlig neu bearb.]. - Tübingen : Narr, 1985. - B. 1. - S. 53.

${ }^{14}$ Schmidt S. J. Bedeutung und Begriff : Zur Fundierung einer sprachphilosophischen Semantik / S. J. Schmidt. - Braunschweig : Vieweg, 1969. - S. 17.

${ }^{15}$ Кияк Т. Р. Перекладознавство (німецько-український напрям) : [підруч. для студ. вищ. навч. закл.] / Т. Р. Кияк, А. М. Науменко, О. Д. Огуй. - К. : Київський нац. університет, 2009. - С. 55.

${ }^{16}$ Möhn D. Fachsprachen. Eine Einführung / D. Möhn, R. Pelka. - Tübingen, Max Niemeyer Verlag, 1984. - S. 26.

${ }^{17}$ Міщенко А. Л. Лінгвістика фахових мов та сучасна модель науково-технічного перекладу : монографія / А. Л. Міщенко. - Вінниця : Нова Книга, 2013. - С. 15.

18 Hoffmann L. Kohärenz und Kohäsion in wissenschaftssprachlichen Texten: ein Analysebeispiel // Fachsprachen. Ein internationales Handbuch zur Fachsprachenforschung und Terminologiewissenschaft. - Berlin - New York, 1998. - S. 614. 
for the study of Languages for Special Purposes. The first regards professional language as a system of linguistic signs. The second is aimed at professional text, as well as its contextual links that make professional communication possible. The third concept is related to the producer and the recipient of professional communication, thereby defining the cognitive properties of humans as the basis of linguistic research ${ }^{19}$.

Languages for Special Purposes can be represented in horizontal and vertical structuring. The horizontal division follows the principle of division according to the disciplines and specialist areas. Thus, there are LSP of consumption and trade, which include, in particular, beekeeping, shipping, book printing, hunting, animal husbandry and more. The next group consists of technical and LSP of applied sciences: computer science, telecommunications, electrical engineering and more. The third group of horizontal division is the LSP of the sciences, which include, in particular, law, physics, chemistry, biology, pharmacology, mathematics, pedagogy, linguistics, as well as theology. The fourth group includes the languages of institutions: politics, governance, etc. ${ }^{20}$ The vertical structuring does not adhere to the professional principle, but takes into account the level of abstractness. Thus, LSP differ in the level of the highest degree of abstraction (artificial symbols, formulas - basic theoretical sciences), the level of very high degree of abstractness (experimental sciences communication between scientists, technicians), high degree of abstraction (languages with a very high proportion of professional terminology and clear syntax - applied sciences), low abstractness (languages with a fairly high proportion of professional terminology and relatively unrelated syntax - the sphere of material production) and very low level of abstraction (languages with few professional terms and unrelated syntax the sphere of consumption and trade) ${ }^{21}$. Vertical structuring manifests itself, in particular, in the pragmatic conditions of the professional communication functioning and in linguistic selection (stylistics). Therefore, theology finds its place in the horizontal structuring and belongs to the LSP of science.

It should be noted that some LSP use specific language means that may be available in other LSP. Multiple subgroups can form larger classes with their common features. Yes, it is possible to distinguish a hierarchical system of LSP of theology and its sublanguages within the national

\footnotetext{
${ }^{19}$ Roelcke T. Fachsprachen / T. Roelcke - Berlin: Erich Schmidt Verlag, 2005. - S. 16-17.

${ }^{20}$ Ibid. - S. 37-38.

${ }^{21}$ Кияк Т. Р. Перекладознавство (німецько-український напрям) : [підруч. для студ. вищ. навч. закл.] / Т. Р. Кияк, А. М. Науменко, О. Д. Огуй. - К. : Київський нац. університет, 2009. - С. 57.
} 
language, in particular, the professional language of moral theology, pastoral theology, homiletics, liturgy, etc.

Languages for Special Purposes are primarily targeted at specialists in a particular field. Each profession has its own linguistic variability. E.S. Movchun, sharing the opinion of the representatives of the German School for the Study of LSP K. Baumann, L. Hoffmann, D. Möhn, R. Pelka, T. Roelcke and H.-R. Fluck, believes that "not only lexical but also syntactic features are inherent in every LSP". The use of certain syntactic constructions and a much smaller proportion of figurative terminological units distinguish Languages for Special Purposes from professional jargon (slang)",22. Professional communication "is closely related to human speech and is the subject of research in a number of related sciences and subdisciplines of general linguistics, including pragmatics, which explores the use of language signs, grammatical structures and stylistic patterns adequate in the professional text to achieve the communicative purpose as well as the terminology that is associated with the professional language in terms of applied terminology and terminological activity, in particular, the formation of modern terminological systems, the problems of term formation, normalization, standardization, harmonization and up-to-date maintenance of industry terminologies at national and international levels"23.

Languages for Special Purposes exist at the level of vocabulary, syntax and text. All vocabulary of the professional text is divided into 4 types:

1) Specialist terms that have their own definition: die Eucharistie (Eucharist), das Jesusgebet (Jesus Prayer), das Sacrament (holy mystery); narrow vocabulary is the most important and the most frequently used in professional texts and carries the greatest amount of information;

2) Interdisciplinary terms (including terms of related sciences): das Leben (life). In philosophy, it is a similar way of realizing existence on separate, every higher degrees of reality. In the scientific sense, life is associated with protoplasm as the highest known form of organization of matter. "From the theological point of view, the fragile 'miracle' of life is first and foremost a gift of God, as chance and creativity are explored in the animated being more clearly than in the inanimate world" ${ }^{\text {; }}$;

${ }^{22}$ Мовчун Є. С. Особливості перекладу українською мовою німецького комерційного Інтернет дискурсу : автореф. дис. на здобуття наук. ступеня канд. філ. наук : спец. 10.02.16 «Перекладознавство» / Є. С. Мовчун. - Київ, 2010. - С. 7.

${ }_{23}$ Міщенко А. Л. Лінгвістика фахових мов та сучасна модель науково-технічного перекладу : монографія / А. Л. Міщенко. - Вінниця : Нова Книга, 2013. - С. 16.

24 Короткий теологічний словник / Карл Рагнер, Герберт Форгрімлєр [перекл. О. Авраменко]. - Львів, 1996. - С. 179 - 180. 
3) Professionalisms, which may include nomenclature: der Rosenweihrauch (incense from rose), der Weihrauch "Ecclesia” (incense made from incense tree);

4) Professional jargon, which does not claim to be precise and unambiguous, it has a high level of imagery and emotionally colored meaning (has not been studied) ${ }^{25}$.

According to A.L. Mishchenko, the basis of a professional text is a terminological vocabulary, "which is the object of the study of terminology as a science of professional concepts and their nominations in professional languages. The main task of theoretical terminology is to create unified and standardized principles and methods of word formation, classification and systematization of branch terminological systems; normalization of the principles of systemic development of branch terminological systems, regulation of relations between concepts within terminological systems, which is the basis of applied terminological activity" ${ }^{26}$.

\section{Terms of the German Christian-theological terminology: Definition of the terms, characteristics}

Terminology is a "special vocabulary serving a particular field of science or technology" 27 . Terminology is used in the language in special subject fields; "this presupposes a division of language into as many speial sublanguages as there are separated subject fields or areas of knowledge and activity in a given linguistic community. From the point of view of terminology, therefore, the lexicon of a language consists of the many separate subsystems representing the knowledge structure of each subject field or discipline" ${ }^{28}$ :

- Bibelwissenschaft (Biblicla Studies): Neues Testamen (New Testament), Altes Testament (Old Testament), die Bibel (the Bible), die Synoptiker (synoptic Gospel);

- systematische Theologie (systematic theology): die Eklesiologie (ecclesiology), die Eschatologie (eschatology), die Trinität (Trinity).

\footnotetext{
${ }^{25}$ Кияк Т. Р. Теорія та практика перекладу (німецька мова) : [підручник для студентів вищих навчальних закладів] / Т. Р. Кияк, О. Д. Огуй, А. М. Науменко. - Вінниця : Нова книга, 2006. - С. 28-29.

26 Міщенко А. Л. Лінгвістика фахових мов та сучасна модель науково-технічного перекладу : монографія / А. Л. Міщенко. - Вінниця : Нова Книга, 2013. - С. 163.

${ }^{27}$ Кияк Т. Р. Лингвистические аспекты терминоведения : [учеб.пособие] / Т. Р. Кияк. К. : УМК ВО, 1989. - С. 7.

${ }^{28}$ Sage J.C. Practical Course in Terminology Processing. - Amsterdam, Philadelphia : John Benjamins Publishing Company, 1990. - P. 13. 
According to O.M. Tours terminological systems have some features. In particular, a terminological system is a set of terms that performs a communicative-thematic or communicative-situational task; elements of the structure are directly or indirectly related; there is no term that does not belong to any particular term system or to several at the same time, and they can overlap one another, forming a group of terms common to several terminological systems ${ }^{29}$. Thus, the terminological unit der Logos in the philosophical system of terms means "speech, intellect”. In the theological terminology it means "the word of God as an objectively manifested will of God and the power of creation of the universe" (Genesis 1: 3; Ps. 33: 6; Jn. 1, 1-3); "Jesus as the Incarnate Word and Divine Revelation” (Jn. 1:14; Rev. 19:13).

Terms as verbal designations of concepts that are included in the system of concepts of a particular area of professional knowledge, and as the basic units of language used for a specific purpose ${ }^{30}$. On the one hand they are important elements of the LSP used by professionals in various fields of science and technology for communication related to professional activity $^{31}$, and on the other hand, belong to a certain terminological system - a consciously constructed system of terms ${ }^{32}$. "Terms are the linguistic representation of concepts.”33. B.M. Golovin believes that the term is a single word or a noun phrase, which means a professional concept and is intended to meet the specific needs of communication in a particular profession ${ }^{34}$. V.A. Tatarinov describes the term as "a linguistic sign (word or phrase) that correlates with a specific concept, phenomenon or object" ${ }^{35}$. O. Selivanova defines the term as "a word or a compound that denotes the concept of a special sphere of communication in science, production, technology, art, in a particular field of knowledge or human activity" ${ }^{36}$. Y. A. Klimovytsky considers the term a word or a phrase,

${ }^{29}$ Тур О. М. Польова структура сучасної української терміносистеми землеустрою та кадастру / О. М. Тур // ЧДУ ім. П. Могили : наукові праці. - Т. 92. - № 79. - С. 69.

${ }^{30}$ Суперанская А. В. Общая терминология : вопросы теории / А. В. Суперанская, Н. В. Подольская, Н. В. Васильева. - [2-е изд. стер.]. - М. : Едиторал УРСС, 2004. - С. 14.

31 Жербило Т. В. Термины и понятия лингвистики : Общее языкознание. Социолингвистика : Словарь-справочник / Т. В. Жербило. - Назрань : Пилигрим, 2011. - С. 215.

32 Лейчик В. М. Терминоведение. Предмет, методы, стрктура : [4-е изд.] / В. М. Лейчик. - М. : Либроком, 2009. -С.107.

${ }^{33}$ Sage J.C. Practical Course in Terminology Processing. - Amsterdam, Philadelphia : John Benjamins Publishing Company, 1990. - P. 57.

${ }^{34}$ Головин Б. М. Термін і слово / Б. М. Головин. - Горький, 1980. - С. 276.

35 Татаринов В. А. Теория терминоведения / Татаринов В. А. - М. : Московский лицей, 1996 . - C. 157.

${ }^{36}$ Селіванова О. Сучасна лінгвістика : термінологічна енциклопедія / О. Селіванова Полтава : Довкілля-К, 2006. - С. 617. 
which is the unity of a sound sign and a corresponding concept in the system of concepts of a given field of science and technology ${ }^{37}$. O.S. Akhmanova calls the term a word or phrase of a special language, which is created to accurately express special concepts and name special objects $^{38}$. The term is a word or phrase that expresses a clearly defined concept of a particular field of science, technology, art, social and political life $^{39}$. The term is a linguistic unit (word or phrase) mostly of a substantive nature, which conventionally relates to the concept and object of the professional field and serves to concentrate, record, store and transmit professional information ${ }^{40}$.

"The term is a member of a particular terminological system, so terminology is not a random set of words, but a system of interrelated terms that denote the system of concepts of a particular branch of knowledge" ${ }^{41}$. Thus, the words die Offenbarung (revelation), die Schisma (schism), das Sacrament (sacrament) reflect the essence of certain theological concepts. The terms for each science are numbered and necessarily related to the concepts of a particular science. Therefore, the specificity of the term lies primarily in the clearly limited field of its use ${ }^{42}$.

The main task of the term is to nominate and optimize the process of professional communication. In this regard, the term should specifically reflect the results of both practical and research activities of the person, consolidate the knowledge acquired in the course of scientific and professional activity about the features of terminological objects, as well as identify their most important features ${ }^{43}$.

The nomination is closely related to such a thinking stage as concept formation. It involves the selection of that particular trait, feature or phenomenon of an object that would later serve as a name. The relationship between the term and the word is close. If a term called

\footnotetext{
${ }^{37}$ Климовицкий Я. А. Некоторые вопросы развития и методологи терминологических работ в СССР / Я. А. Климовицкий. - М. , 1967. - С. 34.

${ }^{38}$ Ахманова О. С. Словарь лингвистических терминов / О. С. Ахманова. - М. : Советская энциклопедия, 1969. - С. 474.

${ }^{39}$ Ганич Д.І. Словник лінгвістичних термінів / Д. І.Ганич, І. С. Олійник. - К. : ВШ, 1985. - С. 306.

40 Лемов А. В. Система, структура и функционирование научного термина / А. В. Лемов. - Саранск : изд-во Мордов. университета, 2000. - С. 77.

${ }^{41}$ Безгодова Н. Співвідношення понять термінологія - професіоналізм - номенклатура (теоретичний аспект) : [Електронний ресурс]. / Надія Безгодова // Вісник Львівського Університету. Серія Філологічна. - Вип. 34. - Ч. 1. - Львів, 2004. - С. 458 - 463. - Режим доступу : http://philology.lnu.edu.ua/v34_1.php.

${ }_{42}$ Реформатский А. А. Мысли о терминологии / А. А. Реформатский // Современные проблемы русской терминологии. - М., 1986. - С. 165-166.

${ }^{43}$ Володина М. Н. Научно-техническая терминология и общеупотребительная лексика : [Електронний ресурс]. - Режим доступу : http://library.krasu.ru/ft/ft/_ articles/0113883.pdf. 148
} 
a word belongs to the field of science or technology, then the word that denotes this term is a scientific and technical term ${ }^{44}$. The same can be said about the theological term: die Eucharistie (Eucharist), die Firmung (Confirmation), Apostolosche Väter (early fathers of the church), die Apokryphen (apocrypha) - the concepts called by these lexical units belong to the science of theology, they reflect the essence of the theological realities, and the words that denote them are Christiantheological terms.

The term as a unit of national language simultaneously belongs to a special linguistic subsystem and therefore serves as a special linguistic unit, which refers to special and professional concepts, which makes it possible to distinguish them among other units of the linguistic system ${ }^{45}$.

The terms are being examined in various terminological systems at the present stage of the development of linguistics. The term has a specific and defined scope and thus belongs to the vocabulary of a particular subtext that serves as a medium of communication in a particular professional field. The term is a part of a terminological system of a particular profession.

The term as "a word or verbal complex enters into systemic relations with other words and verbal complexes and forms with them in each specific case and at certain times a closed system, characterized by high informativeness, uniqueness, accuracy and expressive neutrality" 46 . According to V. Schmidt, the term should have such properties as: professional orientation, content, accuracy, uniqueness, brevity, as well as aesthetic, expressive and modal neutrality ${ }^{47}$. According to A.S. Dyakov, T.R. Kyyak and Z.B. Kudelko, the term is characterized by specific features, such as systematicity, definiteness (each term is compared with a clear, separate definition that focuses on the corresponding concept), brevity (this requirement is often contrary to the requirement of accuracy, i.e. completeness of the term), unambiguity, which should be sought within the same terminosphere, because at the level of several sublanguages the polysemy of the terms is a widespread phenomenon, expressive neutrality ${ }^{48}$. Taking into account the abovementioned, we can

\footnotetext{
${ }^{44}$ Квитко И. С. Термин в научном документе / И. С. Квитко. - Львов : Вища школа, 1976. - C. 9.

${ }^{45}$ Шмелёва О. Ю. Терминологические процессы в диахронии и синхронии (на материале английского языка) / О. Ю. Шмелёва. - С-Пб. : СПбГУЭФ, 2010. - С.10.

${ }^{46}$ Квитко И. С. Термин в научном документе / И. С. Квитко. - Львов : Вища школа, 1976. - C. 21.

${ }^{47}$ Schmidt S. J. Bedeutung und Begriff : Zur Fundierung einer sprachphilosophischen Semantik / S. J. Schmidt. - Braunschweig : Vieweg, 1969. - S. 12.

48 Д'яков А. С. Основи термінотворення: Семантичні та соціолінгвістичні аспекти / Д’яков А. С., Кияк Т. Р., Куделько З. Б. - К. : вид. дім “КМ Аcademia”, С. 13.
} 
conclude that systematicity, definiteness, uniqueness, brevity and accuracy are important properties of the term.

Considering the systematic nature of the term, it should be noted that it operates within a certain terminological system. A system (from gr. $\Sigma v \delta \tau \varepsilon \mu \alpha$ - a conjunction, a whole made up of parts) is a collection of elements that are in appropriate relations and bonds with each other and form a certain unity ${ }^{49}$. According to the dictionary of the Ukrainian language, organization and structure are also included into the system, which is the unity of regularly located and functional parts ${ }^{50}$. The basic element of the system is the structure, "the set of stable links of the object, ensuring its integrity and identity to itself that is, maintaining the main qualities in various external and internal changes". On this basis, the scientific term is a system in which three elements are structured, forming a lexical triangle:

1) the material shell of the word-term;

2) the actuality of objective reality related to it;

3) the concept of this reality ${ }^{51}$.

The term has a meaning in a particular term system because systematicity is one of its main characteristics. The systematicity of terminological unit is manifested, on the one hand, by the reflection of the notion expressed by the term, and on the other - by the motivational wordforming capabilities of the word-sign (term) ${ }^{52}$, for example, das Andreaskreuz (St. Andrew's Cross), das Petrus Kreuz (St. Peter's Cross). The systematicity of a particular term system, including the theological one, is also manifested in the availability of word-families in the terminology (term-families), which are "terms that are united on the basis of the common feature or pattern and have the same component" ${ }^{53}$. Wordfamilies in the terminology are the result of a morphological way of word formation in the terminology with the help of a root word, on the one hand. And on the other hand, of a syntactic way of their constructing, in the process of which the main component acquires the status of the definition, and vice versa, the significant component of the term is given the status

\footnotetext{
${ }^{49}$ Новая философская энциклопедия : [Електронний ресурс]. - Режим доступу : http://iph.ras.ru/elib/2736.html.

${ }^{50}$ Словник української мови : в 11 томах / АН УРСР. Інститут мовознавства / [ред. І. К. Білодід та ін.]. - Київ: Наукова думка, 1970 - 1980. - Т. 9. - С. 204.

51 Лемов А. В. Система, структура и функционирование научного термина / А. В. Лемов. - Саранск : изд-во Мордов. университета, 2000. - С. 8.

${ }^{52}$ Синьо В. В. Лінгвістичні особливості німецької фахової мови лісівництва : дис. канд. філ. наук : 10.02.04 / В. В. Синьо. - Ужгород, 2007. - С. 24.

${ }_{53}$ Бартков Б. И. Частность английских военных терминов и мощность их словообразовательных гнёзд / Б. И. Бартков // Особенности словообразования в системе и литературной норме. - Владивосток : ДВНЦ АН СССР, 1983. - С. 39.
} 
of the basic component of the derivative nomination ${ }^{54,55}$. The presence of the same determinant in a number of composites testifies to the common features in the respective concepts. For example, the term die Kirche (church) is a main component of such terminological units as: die Kirchenlehre (church teaching), der Kirchenvater (church father), die Kirchenstrafe (church punishment), das Kirchenjahr (church year), der Kirchenvorstand (church curatorium), die Kirchenprovinz (church province), etc.

When we refer to such a property of the term as definiteness, we understand that each term is related to a specific concept through definition ${ }^{56}$. The definition is an important condition for distinguishing it from a literary word, as well as for the creation, storage and transmission $\mathrm{f}$ scientific information ${ }^{57}$ :

Die Tugend ist eine beständige, feste Neigung, das Gute zu tun. Sie ermöglicht dem Menschen, nicht nur gute Taten zu vollbringen, sondern sein Bestes zu leisten. Mit all seinen sinnlichen und geistigen Kräften strebt der tugendhafte Mensch nach dem Guten. Er sucht es zu erreichen und entscheidet sich bei seinen konkreten Handlungen dafür ${ }^{58}$.

A virtue is an habitual and firm disposition to do the good. It allows the person not only to perform good acts, but to give the best of himself. The virtuous person tends toward the good with all his sensory and spiritual powers; he pursues the good and chooses it in concrete actions ${ }^{59}$.

For any term system uniqueness, or unambiguity, brevity, and accuracy are an ideal rather than a norm. While polysemy in the general vocabulary leads to the enrichment and expansion of the lexical composition, it is undesirable for the term system because it violates the language's attempt to maintain a clear correspondence between the referent and its nominative sign. In the terminology of many sciences it is much easier to find a polysemic term than an unambiguous one ${ }^{60}$. For example, the terminological unit die Gemeinde (community, parish) stands out as a polysemous one,

${ }^{54}$ Секунда Т. Принципи складання української технічної термінології / Т. Секунда // Вісник Ін-ту укр. наук. мови. - 1930. - Вип. 2. - С. 11-21.

${ }^{55}$ Казарина С. Г. Типологические характеристики отраслевых терминологий / С. Г. Казарина- Краснодар, 1998. - С. 154.

${ }_{56}$ Коваль А. П. Науковий стиль сучасної української літературної мови. Структура наукового тексту / А. П. Коваль. - К. : Видавництво Київського університету, 1970. - С. 262.

57 Лемов А. В. Система, структура и функционирование научного термина / А. В. Лемов. - Саранск : изд-во Мордов. университета, 2000. - С. 42.

${ }^{58}$ Katechismus der Katholischen Kirche : Neuübersetzung aufgrund der Editio typica latina. [2., veränd. Aufl.]. - München, Wien, Oldenbourg, Leipzig : St.-Benno-Verlag, 2003. - S. 476.

${ }^{59}$ Catechism of the Catholic Church : [Електронний ресурс]. - Режим доступу : http://www.vatican.va/archive/ENG0015/P64.HTM.

60 Лемов А. В. Система, структура и функционирование научного термина / А. В. Лемов. - Саранск : изд-во Мордов. университета, 2000.- С. 46. 
where the first meaning is an administrative unit (parish) in a church or religious congregation, and the second meaning is the gathering of all members of the parish for worship. The ambiguity of the term, namely the ability of the polysemous terms to belong to different paradigmatic series, leads to the emergence of synonymic, antonymic and homonymous relations, which are characteristic of the current terminological situation ${ }^{61}$. Ideally, the term should not have synonyms. However, in the term system under investigation the phenomenon of synonymy is present: die Fleischwerdung, die Menschenwerdung, die Incarnation - all these three terms mean incarnation.

Accuracy is the most appropriate correlation between linguistic expressions and objects, states or processes of the respective branches of human activity ${ }^{62}$. According to V. Sinyo, "the requirement of precision of a term means that it must contain essential features of the concept defined.


high precision of their concept: der Kreuzweg (the Stations of the Cross), die Glaubensspaltung (split of the church), das Glaubensbekenntnis (the creed, the symbol of faith). The short terms of the terminology we are exploring (partly from Latin and Greek) have a very high degree of accuracy, for example, der Exarch (Latin exarchus - Vorgesetzter < Gr. $\xi \alpha \rho \chi o \varsigma$ Anführer sein) (exarch), das Filioque (Lat. und vom Sohn) (Filioque), die Gnade (Old High German gnada - Wohlwollen, Gunst < Lat. gratia < Gr. Xópıs (mercy, mercy).

Along with the properties of the term having already been mentioned, the motivation of the terminological unit plays an important role. Although language is not exclusively composed of motivated lexical units, each linguistic system contains a reasonably high proportion of motivated potential. The language system as a whole is aimed at increasing the capacity of motivation in such a way as to restore or re-create the connection of motivation. In response to the constant phonological and semantic changes that destroy the link of motivation, compensatory changes are coming to the fore. They link the formal and the internal form of language more closely, rationally forming the link between form and meaning ${ }^{64}$. F. de Saussure believes that motivation is more complete,

61 Закреницька Л. А. Англійська християнсько-богословська терміносистема : генезис, структура, семантика : дис. канд. філ. наук : 10.02.04 / Л. А. Закреницька. - Хмельницький, 2011. - C. 29.

${ }^{62}$ Roelcke T. Fachsprachen / T. Roelcke - Berlin: Erich Schmidt Verlag, 2005. - S. 61.

${ }^{63}$ Синьо В. В. Лінгвістичні особливості німецької фахової мови лісівництва : дис. канд. філ. наук : 10.02.04 / В. В. Синьо. - Ужгород, 2007. - С. 26.

${ }^{64}$ Wurzel W. U. Zur Dialektik im Sprachsystem : Widerspruch - Motiviertheit Sprachveränderung / W. U. Wurzel // Deutsch als Fremdsprache. - 1984. - S. 208. 
the easier it is to decompose it into parts from which one can understand the meaning of the whole ${ }^{65}$.

Considering the problem of motivation at the level of the term system, it should be noted that terms based on word-forming resources of both the native language and formed on the basis of borrowed term elements can be motivated. However, they are motivated in different ways. In one case it is often a question of metaphor or metonymy, in another it is a term motivated by a corresponding set of term elements ${ }^{66}$. Motivation is the mediator between the form and the content of the sign. The name, or rather its internal form, which is interpreted as the "basis of motivation" is a means of motivation process ${ }^{67}$. This is the internal form of the word "that induces articulate sound to express the thought taken in the totality of its connections and systematicity" ${ }^{\text {68 }}$. It does not come down only to the etymology of the word, or to the lexical meaning, to the motivation, or to the simple sum of the meanings of the constituent morphemes. $<\ldots>$ The internal form is a mental interiorized image, potentially abstracting and displaying, in the form of an apperception, one or more essential features of denotation, evoked and fixed in the memory of the native speaker by the morphemic structure of the word or expression" ${ }^{\text {"69 }}$.

V. Fleischer and S. Ulmann distinguish three types of motivation: phonetic-phonemic, morphological-semantic and figurative ${ }^{70}$, ${ }^{71}$. A.S. Dyakov, T.R. Kyyak and Z.B. Kudelko suggest a somewhat different division and distinguish between three types of motivation, such as: sign (semiotic), formal (word-forming) and content (intense). The very fact of existence and use of the word points to the sign motivation, since there are no totally unmotivated lexical units in the language. All of them are in some way interrelated with the corresponding meaning, at least at the level of the common vocabulary. Formal motivation includes external form motivation and internal form motivation (morphological and semantic) ${ }^{72}$.

${ }^{65}$ Соссюр де Ф. Курс общей лингвистики / Ф. де Соссюр. - Екатеринбург : изд-во Урал. ун-та, 1999. - С. 157.

${ }_{66}^{66}$ Суперанская А. В. Общая терминология : вопросы теории / А. В. Суперанская, Н. В. Подольская, Н. В. Васильева. - [2-е изд. стер.]. - М. : Едиторал УРСС, 2004. - С. 107

${ }^{67}$ Прядохин М. Г. Пособие по изучению нового китайского фонетического алфавита : текст / М. Г. Прядохин. - М. : Восточная литература, 1960. - 9 с.

${ }^{68}$ Потебня А. А. Из записок по русской грамматике. Об изменении значения и заменах существительного / А. А. Потебня. - М. : Просвещение, 1968. - Т. 3. - С. 116.

69 Д'яков А. С. Основи термінотворення: Семантичні та соціолінгвістичні аспекти / Д'яков А. С., Кияк Т. Р., Куделько 3. Б. - К. : вид. дім “КМ Аcademia”, 2000 - С. 73 - 74.

${ }^{70}$ Fleischer B. Wortbildung der deutschen Gegenwartssprache / B. Fleischer, H. Bartz. Tübingen, 1992. - S. 14.

${ }^{71}$ Ullmann S. The principles of Semantics / S. Ullmann. - Glasgow, 1963. - P. 52.

72 Д'яков А. С. Основи термінотворення: Семантичні та соціолінгвістичні аспекти / Д'яков А. С., Кияк Т. Р., Куделько 3. Б. - К. : вид. дім “КМ Academia”, 2000 - С. 81. 
Morphological-semantic motivation by internal form encompasses the relation between words at the morphological and semantic levels. According to E.S. Kubriakova, "the key to the semantic reading and interpretation of any word is, after all, its superficial morphological structure" ${ }^{\text {,3 }}$. Morphological motivation is first and foremost defined by a word-forming model of the lexical unit, such as the suffix -ung: die Bekehrung (conversion). Semantic motivation is the result of the relationship between word-forming formants and the word stem, between the new and the previous meaning: die Heiligsprechung (proclamation of the saints) ${ }^{74}$.

Intense motivation is a "structural-semantic characteristic of a lexical unit explaining a rational lexical-semantic link between the meaning and the internal form of the given unit by means of language,"75. It acts as a link between the form and the semantic content of the language sign; it is determined by the ability of the internal form to display the most relevant features of the linguistic content of a word or expression, establishes its structural and semantic features in comparison with lexical meaning. ${ }^{76}$ Content motivation is clearly evident, first of all, in Christian theological terms-composites in the German language.

Internal form and motivation may contain different amount of information. Accordingly, we distinguish:

1) the full motivation of the inner form (when the form reflects a feature that is completely included in the meaning): der Kelchtuch ein Leientüchlein zum Austrocknen des Meßkelches (lention);

2) partial motivation (when there is a part of the linguistic content of the unit which is common to the internal form and lexical meaning) : Christi Himmelfahrt - Aufnahme Christi in den Himmel (Ascension);

3) absence of motivation (no morpheme included in the internal form has a corresponding meaning): das Pontifikalamt - von einem Bischof gehaltene feierliche Messe (festive Worship);

4) absolute motivation (complete coincidence of semantic features of internal form and lexical meaning): die Fastenpredigt - Predigt in der Fastenzeit (sermon at the time of fasting) ${ }^{77}$.

${ }^{73}$ Кубрякова Е. С. Типы языковых значений : Семантика производного слова / Е. С. Кубрякова. - М. : Наука, 1981. - С. 19.

74 Д'яков А. С. Основи термінотворення: Семантичні та соціолінгвістичні аспекти / Д’яков А. С., Кияк Т. Р., Куделько З. Б. - К. : вид. дім “КМ Асаdemia”, 2000 - С. 81.

${ }^{75}$ Кияк Т. Р. Лингвистические аспекты терминоведения : [учеб.пособие] / Т. Р. Кияк. К. : УМК ВО, 1989. - С. 38.

76 Д'яков А. С. Основи термінотворення: Семантичні та соціолінгвістичні аспекти / Д’яков А. С., Кияк Т. Р., Куделько З. Б. - К. : вид. дім “КМ Асаdemia”, 2000 - С. 83.

${ }_{77}^{7 и я к ~ Т . ~ Р . ~ Л и н г в и с т и ч е с к и е ~ а с п е к т ы ~ т е р м и н о в е д е н и я ~: ~[у ч е б . п о с о б и е] ~ / ~ Т . ~ Р . ~ К и я к . ~-~}$ К. : УМК ВО, 1989. - С. 39. 
Full motivation can be considered the most appropriate, since form and meaning are mutually consistent in it, which promotes, as a rule, better mutual understanding. Thus, motivation is a significant feature of the term. It is characteristic primarily for derivative terms and composite terms. It serves as a connecting element between the form and the content of the sign. There are two divisions of motivation. One division characterizes the amount of information contained in the internal form of the sign, and, accordingly, we can distinguish between full, partial, absolute motivation and its absence. Another considers sign, formal and content motivation.

\section{CONCLUSIONS}

Summarizing the previously mentioned, we can conclude that the professional language of theology is the totality of all linguistic means used in the theological field of communication to ensure understanding between people in this field. The theological language of theology, which exists at the level of vocabulary, syntax and text, includes theological terms. Theological terms form the terminological system of theology that serves theology as a field of science.

Basing on the results of our research, we can claim that German Christian-theological terms are systemic, definable, and partly characterized by unambiguity, accuracy and brevity. The systematicity of the studied terminological system is based on the word-family in the German terminology of theology. The presence of the same determinant in a number of composites indicates common ground in the relevant concepts. The terms of Christian-theological terminological system relate to specific concepts through definitions. Partial uniqueness of German Christian-theological terms is conditioned by the presence of polysemy and synonymy available in the studied term system. Motivation is an important feature of the term, clearly traced to derivative terms and composite terms, and serves as a connecting element between the form and meaning of the sign.

\section{SUMMARY}

In the following research, the author gives a general overview of the theological terminology in German. The connection between Languages for Special Purposes and terminology is settled. The horizontal and vertical structuring of the Languages for Special Purposes and the place of theology as science are presented there. Aspects of motivation have been analysed. For the first time, the German terms of professional theological language at the level of vocabulary have been analysed. The terms of German Christian theological terminology according to the motivation aspect and the aspect of definitiveness have been studied. 


\section{REFERENCES}

1. Ахманова О. С. Словарь лингвистических терминов / О. С. Ахманова. - М. : Советская энциклопедия, 1969. - 608 с.

2. Бартков Б. И. Частность английских военных терминов и мощность их словообразовательных гнёзд / Б. И. Бартков // Особенности словообразования в системе и литературной норме. Владивосток : ДВНЦ АН СССР, 1983. - С. 38-48.

3. Безгодова Н. Співвідношення понять термінологія - професіоналізм - номенклатура (теоретичний аспект) : [Електронний ресурс]. / Надія Безгодова // Вісник Львівського Університету. Серія Філологічна. - Вип. 34. - Ч. 1. - Львів, 2004. - с. 458 - 463. - Режим доступу : http://philology.lnu.edu.ua/v34_1.php.

4. Володина М. Н. Научно-техническая терминология и общеупотребительная лексика : [Електронний ресурс]. - Режим доступу : http://library.krasu.ru/ft/ft/_ articles/0113883.pdf.

5. Ганич Д.І. Словник лінгвістичних термінів / Д. І. Ганич, I. С. Олійник. - К. : ВШ, 1985. - 360 с.

6. Головин Б. М. Термін і слово / Б. М. Головин. - Горький, 1980. - $156 \mathrm{c}$.

7. Греческо-русский словарь / [под ред. А.Д. Вейсмана]. С. Петербург, 1899. - 1368 с.

8. Д'яков А. С. Основи термінотворення: Семантичні та соціолінгвістичні аспекти / Д'яков А. С., Кияк Т. Р., Куделько 3. Б. К. : Вид. дім «КМ Аcademia», $2000-218$ с.

9. Жербило Т. В. Термины и понятия лингвистики : Общее языкознание. Социолингвистика : Словарь-справочник / Т. В. Жербило. - Назрань : Пилигрим, 2011. - 280 с.

10.Закреницька Л. А. Англійська християнсько-богословська терміносистема : генезис, структура, семантика : дис. канд. філ. наук : 10.02.04 / Л. А. Закреницька. - Хмельницький, 2011. - 243 с.

11.Казарина С. Г. Типологические характеристики отраслевых терминологий / С. Г. Казарина- Краснодар, 1998. - 276 с.

12.Катехизм Української Греко-Католицької Церкви : Христос наша Пасха. - Львів : Свічадо, 2011. - 336 с.

13. Католическая Энциклопедия в 5-ти томах. - М. : Издательство Францисканцев, 2002. - Т. 1. - 1906 с.

14.Квитко И. С. Термин в научном документе / И. С. Квитко. Львов : Вища школа, 1976. - 128 с.

15.Кияк Т. Р. Лингвистические аспекты терминоведения : [учеб.пособие] / Т. Р. Кияк. - К. : УМК ВО, 1989. - 104 с. 
16.Кияк Т. Р. Теорія та практика перекладу (німецька мова) : [підручник для студентів вищих навчальних закладів] / Т. Р. Кияк, О. Д. Огуй, А. М. Науменко. - Вінниця : Нова книга, 2006. - 592 с.

17.Кияк Т. Р. Перекладознавство (німецько-український напрям) : [підруч. для студ. вищ. навч. закл.] / Т. Р. Кияк, А. М. Науменко, О. Д. Огуй. - К. : Київський нац. університет, 2009. - 544 с.

18. Климовицкий Я. А. Некоторые вопросы развития и методологии терминологических работ в СССР / Я. А. Климовицкий. М., 1967. - C. 34.

19. Коваль А. П. Науковий стиль сучасної української літературної мови. Структура наукового тексту / А. П. Коваль. - К. : Видавництво Київського університету, 1970. - 306 с.

20.Короткий теологічний словник / Карл Рагнер, Герберт Форгрімлєр [перекл. О. Авраменко]. - Львів, 1996. - 663 с.

21.Кубрякова Е. С. Типы языковых значений : Семантика производного слова / Е. С. Кубрякова. - М. : Наука , 1981. - 200 с.

22. Лейчик В. М. Терминоведение. Предмет, методы, стрктура : [4-е изд.] / В. М. Лейчик. - М. : Либроком, 2009. - 256 с.

23. Лемов А. В. Система, структура и функционирование научного термина / А. В. Лемов. - Саранск : изд-во Мордов. университета, 2000. - $192 \mathrm{c}$.

24. Міщенко А. Л. Лінгвістика фахових мов та сучасна модель науково-технічного перекладу : монографія / А. Л. Міщенко. Вінниця : Нова Книга, 2013. - 448 с.

25. Мовчун С. С. Особливості перекладу українською мовою німецького комерційного Інтернет дискурсу : автореф. дис. на здобуття наук. ступеня канд. філ. наук : спец. 10.02.16 «Перекладознавство» / Є. С. Мовчун. - Київ, 2010. - 21 с.

26.Новая философская энциклопедия : [Електронний ресурс]. Режим доступу : http://iph.ras.ru/elib/2736.html.

27. Обер о. Ж.-М. Моральне богослов'я / о. Жан-Марі Обер : [переклад з італ. о. д-ра М. І. Любачівського] : [2-ге вид, виправ.]. Львів : Стрім, 1997. - 287 с.

28.Потебня А. А. Из записок по русской грамматике. Об изменении значения и заменах существительного / А. А. Потебня. М. : Просвещение, 1968. - Т. 3. - 551 с.

29.Прядохин М. Г. Пособие по изучению нового китайского фонетического алфавита : текст / М. Г. Прядохин. - М. : Восточная литература, 1960. - 21 с. 
30.Реформатский А. А. Мысли о терминологии / А. А. Реформатский // Современные проблемы русской терминологии. - М., 1986. С. $163-198$.

31.Секунда Т. Принципи складання української технічної термінології / Т. Секунда // Вісник Ін-ту укр. наук. мови. - 1930. Вип. 2. - С. 11-21.

32. Селіванова О. Сучасна лінгвістика : термінологічна енциклопедія / О. Селіванова - Полтава : Довкілля-К, 2006. - 716 с.

33. Синьо В. В. Лінгвістичні особливості німецької фахової мови лісівництва : дис. канд. філ. наук : 10.02.04 / В. В. Синьо. - Ужгород, 2007. -223 c.

34. Словник української мови : в 11 томах / АН УРСР. Інститут мовознавства / [ред. І. К. Білодід та ін.]. - Київ: Наукова думка, 1970 1980. - Т. 9. -915 c.

35. Соссюр де Ф. Курс общей лингвистики / Ф. де Соссюр. Екатеринбург : изд-во Урал. ун-та, 1999. - 432 с.

36. Стасяк С.-Я. Основи догматичного богослов'я / о. С.-Я. Стасяк, о. Р. Завіла. - Львів : Місіонер, 1997. - 310 с.

37. Суперанская А. В. Общая терминология : вопросы теории / А. В. Суперанская, Н. В. Подольская, Н. В. Васильева. - [2-е изд. стер.]. - М. : Едиторал УРСС, 2004. - 248 с.

38. Татаринов В. А. Теория терминоведения / Татаринов В. А. М. : Московский лицей, 1996 . - 311 с.

39. Термінологічно-правописний порадник для богословів та редакторів богословських текстів. - Львів, вид. Інституту богословської термінології та перекладів Українського Католицького Університету, 2005. - 130 с.

40.Тур О. М. Польова структура сучасної української терміносистеми землеустрою та кадастру / О. М. Тур // ЧДУ ім. П. Могили : наукові праці. - Т. 92. - № 79. - С. 68-72.

41.Шмелёва О. Ю. Терминологические процессы в диахронии и синхронии (на материале английского языка) / О. Ю. Шмелёва. С-Пб. : СПбГУЭФ, 2010. - 120 с.

42. Catechism of the Catholic Church : [Електронний ресурс]. - Режим доступу : http://www.vatican.va/archive/ENG0015/_P17.HTM\#7X.

43.Duden, Etymologie : Herkunftswörterbuch der deutschen Sprache / [bearb. von G. Drosdowski]. - Mannheim, Leipzig, Wien, Zürich : Dudenverlag, 1997. - 839 S.

44. Fleischer B. Wortbildung der deutschen Gegenwartssprache / B. Fleischer, H. Bartz. - Tübingen, 1992. - 375 S. 
45. Hoffmann L. Kohärenz und Kohäsion in wissenschaftssprachlichen Texten: ein Analysebeispiel // Fachsprachen. Ein internationales Handbuch zur Fachsprachenforschung und Terminologiewissenschaft. - Berlin New York, 1998. - S. 610-617.

46. Hoffmann L. Kommunikationsmittel Fachsprache / L. Hoffmann // Forum für Fachsprachen-Forschung. - [2., völlig neu bearb.]. - Tübingen : Narr, 1985. - B. 1 - 307 S.

47.Katechismus der Katholischen Kirche : Neuübersetzung aufgrund der Editio typica latina. - [2., veränd. Aufl.]. - München, Wien, Oldenbourg, Leipzig : St.-Benno-Verlag, 2003. - 824 S.

48. Möhn D. Fachsprachen. Eine Einführung / D. Möhn, R. Pelka. Tübingen, Max Niemeyer Verlag, 1984. - $171 \mathrm{~S}$.

49. Roelcke T. Fachsprachen / T. Roelcke - Berlin: Erich Schmidt Verlag, 2005. - 253 S.

50. Sage J.C. Practical Course in Terminology Processing. - Amsterdam, Philadelphia : John Benjamins Publishing Company, 1990. - 264 p.

51.Schmidt S. J. Bedeutung und Begriff : Zur Fundierung einer sprachphilosophischen Semantik / S. J. Schmidt. - Braunschweig : Vieweg, 1969. - $176 \mathrm{~S}$.

52.St. Thomas Aquinas : [Електронний ресурс]. - Режим доступу : https://dhspriory.org/thomas/summa/FP/FP001.html\#FPQ1OUTP1

53. Ullmann S. The principles of Semantics / S. Ullmann. - Glasgow, 1963. $-352 \mathrm{p}$.

54. Wurzel W. U. Zur Dialektik im Sprachsystem : Widerspruch Motiviertheit - Sprachveränderung / W. U. Wurzel // Deutsch als Fremdsprache. - 1984. - S. $201-211$.

Information about the author: Veresh M. T.,

Candidate of Philological Sciences, Associate Professor at the Faculty of Foreign Philology, Department of German Philology,

Uzhhorod National University 3, Narodna Sq., Uzhhorod, 88000, Ukraine 
Publishing house "Liha-Pres"

9 Kastelivka str., Lviv, 79012, Ukraine

44 Lubicka str., Toruń, 87-100, Poland

Printed by the publishing house "Liha-Pres"

Passed for printing: October 15, 2019.

A run of 150 copies. 